UNIVERSIDADE DE BRASÍLIA

GUILHERME DE FREITAS KUBISZESKI

\title{
A PHANTASÍA NA TEORIA ARISTOTÉLICA DA ALMA: Sentidos e Dimensões
}

Brasília

2016 


\section{GUILHERME DE FREITAS KUBISZESKI}

\section{A PHANTASÍA NA TEORIA ARISTOTÉlICA DA ALMA: Sentidos e Dimensões}

Trabalho apresentado no Programa de Pós-Graduação em Filosofia da Universidade de Brasília como prérequisito para a obtenção do título de Mestre em Filosofia. Linha de Pesquisa: Filosofia Antiga e Medieval. Orientadora: prof. $^{\text {a }}$ Dr. $^{\text {a }}$ Loraine de Fátima Oliveira.

Brasília 


\section{A PHANTASÍA NA TEORIA ARISTOTÉLICA DA ALMA: Sentidos e Dimensões}

Esta dissertação foi julgada adequada pela banca examinadora como prérequisito para a obtenção do título de Mestre em Filosofia e aprovada em sua forma final pelo Programa de PósGraduação em Filosofia da Universidade de Brasília.

BANCA EXAMINADORA

Prof $^{\mathrm{a}}$. Dra ${ }^{\mathrm{a}}$. Loraine de Oliveira (UnB)

Prof. Dr. Raphael Zillig (UFRGS)

Prof. Dr. Gabriele Cornelli (UnB)

Brasília 


\section{AGRADECIMENTOS}

Agradeço, primeiramente, a Deus, cujos insondáveis desígnios possibilitaram a consecução deste trabalho.

Agradeço também à minha orientadora, $\mathrm{Dr}^{\mathrm{a}}$. Loraine Oliveira, por toda a ajuda oferecida ao longo de tantos anos de pesquisa e estudo, e aos membros da banca avaliadora, por sua disponibilidade. Aos demais mestres que em algum momento me auxiliaram e me inspiraram, registro aqui minha sincera gratidão.

À minha família, agradeço pelo zelo na educação que me foi proporcionada.

Por fim, agradeço a Claudia Schirmbeck, por todo o amor e companheirismo. 


\section{RESUMO}

Este trabalho tem por objeto abordar o problema da multiplicidade de sentidos atrelados ao termo "phantasía" nas obras de Aristóteles voltadas para o tema da alma. Após introduzir as principais tendências de interpretação sobre a phantasía aristotélica encontradas na literatura secundária, busca-se, na primeira parte, demonstrar a centralidade da noção de movimento intrapsíquico para os sentidos psicológicos do termo. Na parte seguinte, aborda-se o sentido não psicológico de phantasía, evidenciando-se suas dimensões filosóficas. Para tanto, lança-se mão do estudo de tratados como De Sensu et Sensibilibus, De Caelo, Metereologica e De Coloribus. No capítulo final, empreende-se uma análise filosófico-semântica das formas vocabulares do De Anima, a fim de tornar claro o quão arraigado é o vínculo entre phantasía psicológica e movimento na teoria aristotélica da alma. Após essa análise filosóficosemântica, as descrições enunciadas em 428a1 429a2 são estudadas à luz dos Segundos Analíticos e dos Tópicos.

Palavras-chave: Aristóteles, Alma, Faculdade, Movimento, Afecção, Definiçãa 


\begin{abstract}
This work aims to tackle the problem of the plurality of senses the word "phantasia" can have in Aristotle's treatises on the subject of the soul. After presenting the main interpretative trends found in secondary literature, we endeavor to show, in the first part, that the notion of movement is essential to the psychological senses of "phantasía". In the next part, we tackle the non-psychological sense of "phantasía" and exhibit its philosophical dimensions. In order to do this, we study works such as De Sensu et Sensibilibus, De Caelo, Meteorologica and De Coloribus. In the final chapter, we develop a semantico-philosophical analysis of the linguistic forms used in De Anima, in order to show the extent to which psychological phantasia and movement are linked. After that analysis, we study the descriptions stated in 428a1 429a2 in light of the theory developed in Posterior Analytics and Topics.
\end{abstract}

Keywords: Aristotle, Soul, Faculty, Movement, Affection, Definition 


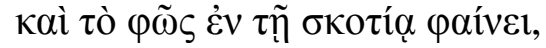

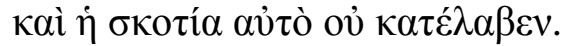
(Jo., 1, 5)

Phantoms and images do undoubtedly exist in that sense, whatever it is, in which ordinary objects exist. I mean, if you shut your eyes and imagine some visual scene, the images that are before your mind while you are imagining are undoubtedly there. They are images, something is happening, and what is happening is that the images are before your mind, and these images are just as much part of the world as tables and chairs and anything else.

(Russell, The Philosophy of Logical Atomism) 


\section{SUMÁRIO}

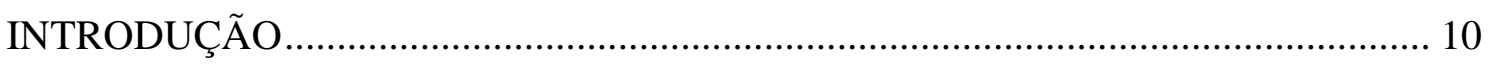

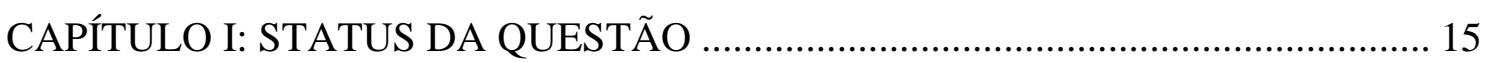

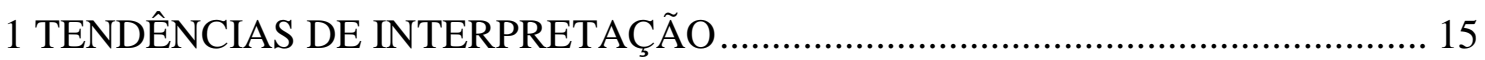

1.1. A não necessidade do conceito de imagem ……………………………...... 15

1.2. Segunda tendência: a necessidade do conceito de imagem ............................... 17

2 UM PRIMEIRO PROBLEMA: A MULTIPLICIDADE DOS FENÔMENOS........... 19

2.1. A abordagem não reducionista ...................................................................... 21

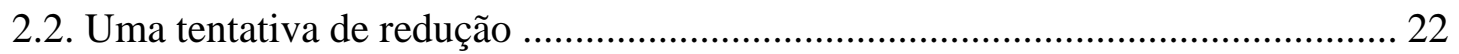

3 EM DEFESA DA PLURALIDADE SEMÂNTICA ………………………………... 27

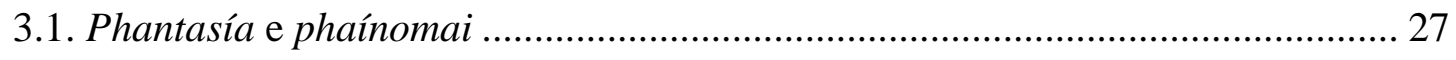

3.2. O De Insomniis e as aparências enganadoras ................................................. 29

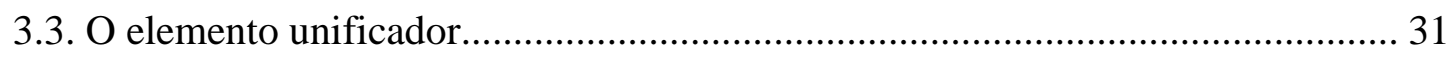

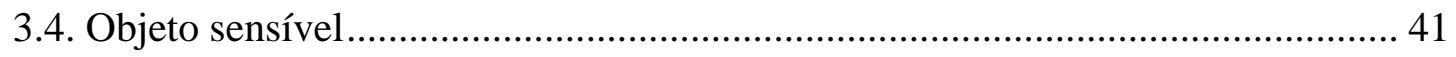

3.5. A pluralidade semântica na filosofia de Aristóteles ............................................. 44

CAPÍTULO II: O SENTIDO NÃO PSICOLÓGICO DA PHANTASÍA ........................... 46

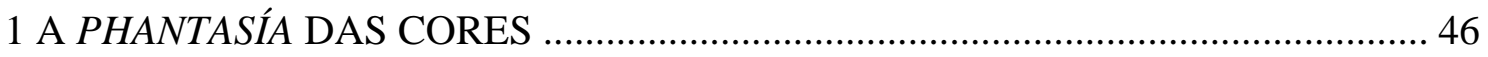

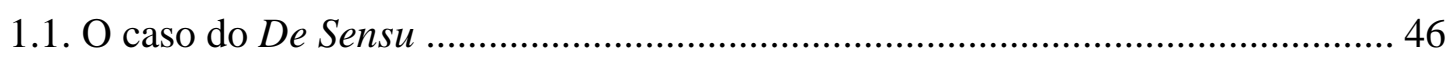

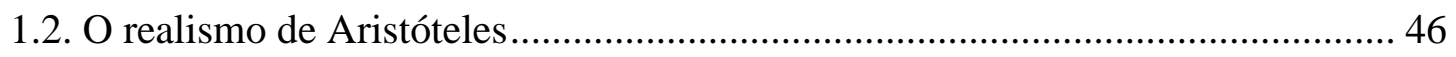

1.3. Uma dimensão psicológica insuperável? ............................................................ 48

1.4. Aparência interna e aparência externa ………………………………………….... 50

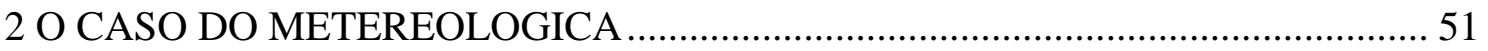

3 PHANTASÍA E CORPOS CELESTES: DE CAELO E METEOROLOGICA ….......... 53

3.1. A phantasía das estrelas................................................................................. 53

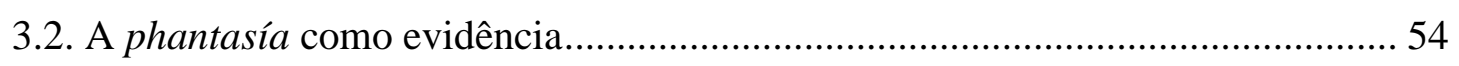

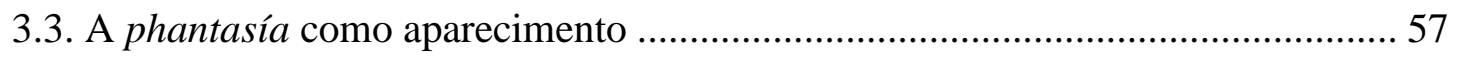

3.4. A phantasía como fenômeno ……………………………………………….... 58

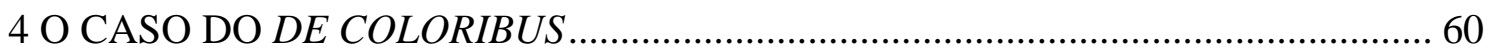

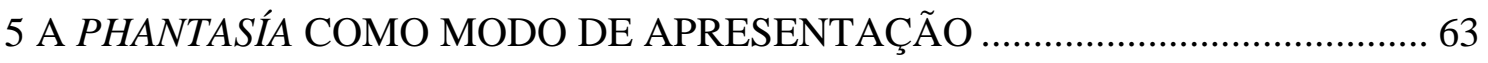

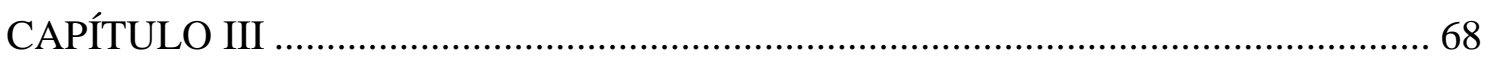

1 PHANTASÍA E MOVIMENTO NA TERMINOLOGIA DO DE ANIMA …................ 74

1.1. Formas linguísticas e conceitos psicológicos ....................................................... 75

1.2. Parte e atividade psíquica em outras passagens do De Anima .............................. 76 


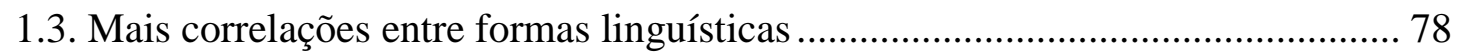

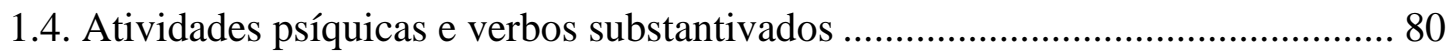

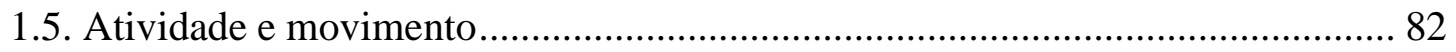

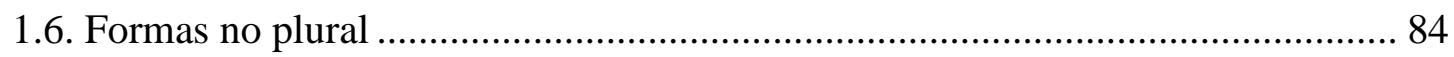

1.7. Relações entre "phantasía" e verbos substantivados .......................................... 88

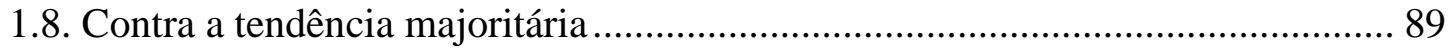

2 NOTAS SOBRE A DEFINIÇÃO DE PHANTASÍA ............................................... 91

2.1. Comentando o DA III.3 à luz dos Segundos Analíticos ...................................... 92

2.2. O problema da phantasía como faculdade ........................................................ 94

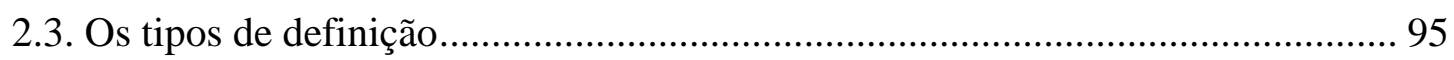

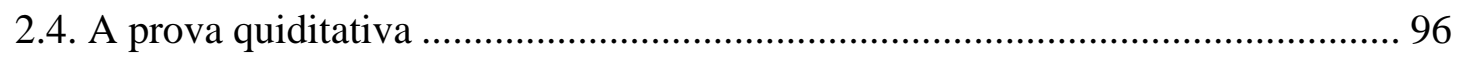

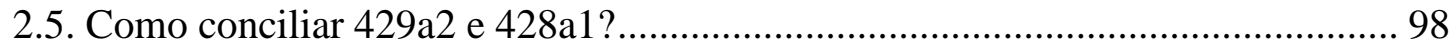

2.6. Tentando enquadrar 429a1 em uma prova quiditativa.................................... 101

2.7. Seria 429a1 realmente uma definição? ............................................................ 104

2.8. O engendramento de phantásmata como uma propriedade............................... 110

2.9. A ideia de função afetiva/afecção funcional .................................................... 112

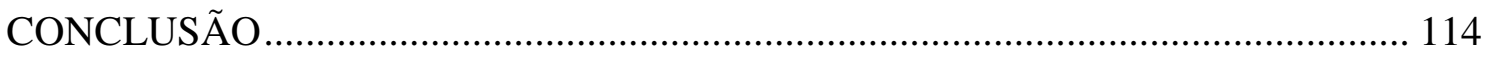

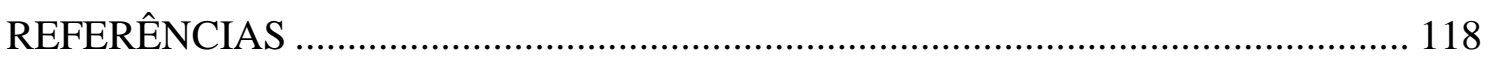




\section{INTRODUÇÃO}

Os estudiosos divergem sobre a existência de uma noção unificada de phantasía no contexto das obras de Aristóteles (WATSON, 1982, 100). Ligado a fenômenos psíquicos tão diversos como o ato imaginativo e a aparência sensorial enganadora, o conceito parece ameaçar não apenas a possibilidade de uma tradução precisa, mas também a própria consistência interna da doutrina de Aristóteles. Faz-se necessário, paralelamente ao distanciamento de esquemas conceituais anacrônicos e os intransponíveis abismos por eles criados, um retorno aos fundamentos da teoria aristotélica da alma ${ }^{1}$, estejam estes explícitos ou implícitos no corpus. Nesta pesquisa, tal retorno representa uma tentativa de abordar o problema imposto pela existência de múltiplos sentidos do termo "phantasía". O problema da polissemia dá origem a três questões: 1) qual é a relevância filosófica dos sentidos de phantasía os quais não correspondem às ideias de imaginação ou fenômeno psíquico ${ }^{2}$ ? 2) qual é, exatamente, o significado da inovação de Aristóteles? 3) como conciliar as diferentes descrições do fenômeno fornecidas no De Anima III?

Em suma, o problema da polissemia incita o intérprete de Aristóteles a empreender tanto um estudo comparativo, o qual investiga as possíveis influências de tradições precedentes no uso do termo "phantasía" por parte de Aristóteles, quanto uma análise filosófico-semântica capaz de avaliar se o conceito apresentado no De Anima compromete a consistência interna da teoria da alma ali desenvolvida.

O presente trabalho, sem negligenciar a riquíssima pluralidade semântica assumida pelo termo "phantasía" - mas, ao contrário, revelando-a e sondando suas reais dimensões -, tenciona salvaguardar a consistência do pensamento de Aristóteles acerca da alma, harmonizando diferença e semelhança dentro de um contexto de herança terminológica e esforço teórico inovador. A centralidade do conceito, o qual efetua, no âmbito epistemológico, a mediação entre sensação e intelecto e do qual depende, no ético, a tomada de decisões, é, por si só, suficiente para justificar uma análise

\footnotetext{
${ }^{1}$ As expressões "teoria da alma" e "psicologia" serão utilizadas, ao longo do trabalho, como sinônimas, ambas referindo-se a um mesmo objeto - a totalidade dos escritos de Aristóteles cujo tema é a natureza da alma e suas funções. Dessa forma, é possível discorrer sobre sentidos não psicológicos de um termo que ocorrem no contexto da própria psicologia desenvolvida pelo filósofo.

2 Tais sentidos, ligados aos conceitos de aparência e manifestação, são aqui denominados "não psicológicos", em virtude de não corresponderem, ao menos primariamente, a alguma atividade da alma.
} 
aprofundada. Contudo, anterior ao estudo de tais papéis há o problema ligado à definição de phantasía e aos elementos que hão de nele estar presentes. Esta pesquisa volta-se, pois, aos fundamentos da questão.

Uma vez que se pretende abordar de modo efetivo a questão da definição de phantasía, torna-se indispensável não apenas um balanço geral das leituras empreendidas pelos comentadores hodiernos, mas também as diretrizes fornecidas pelo próprio Aristóteles referentes à construção de enunciados que descrevem a essência das coisas e dos fenômenos. Dessa forma, este trabalho não se limita a confrontar o $D e$ Anima com as demais obras referentes à alma e seus vários aspectos e funções, mas intenta, paralelamente a tal confronto, buscar no Órganon - mais especificamente, nos Segundos Analíticos e nos Tópicos - subterfúgios para salvaguardar a consistência da visão de Aristóteles sobre o tema da phantasía, bem como para salientar a força do vínculo existente entre esse conceito e a ideia de movimento, vínculo esse que recebe pouca atenção na literatura secundária, notadamente em função da novidade introduzida pelo filósofo ao englobar a phantasía no conjunto das faculdades anímicas ${ }^{3}$.

Não existe, por trás das páginas presentes, a intenção de dirimir a conexão, privilegiada por alguns comentadores hodiernos, entre phantasía e faculdade psíquica nos escritos de Aristóteles sobre a alma. De maneira alguma se procura, no que se segue, substituir a noção de faculdade por outro conceito, mas mostrar que a phantasía, tal como apresentada no De Anima, permite falar de uma interseção possível entre a classe das funções anímicas e a dos movimentos intrapsíquicos. Em outras palavras, tentar-se-á demonstrar que a inovação do Estagirita é, em um sentido fundamental, conservativa em relação à abordagem platônica precedente. Esse entrelaçamento entre ruptura e inovação permite, como será demonstrado, a descoberta de um conceito implícito na abordagem de Aristóteles sobre a phantasía enquanto função psíquica: o conceito de função afetiva ou afecção funcional, i.e., algo que é simultaneamente faculdade anímica e movimento intrapsíquico. Tal conceito, a despeito de anular a dicotomia entre função e afecção, não acarreta, como ficará evidente, o abandono da diferença fundamental entre faculdade e produto.

Se na abordagem detalhada - e, em grande medida, inovadora - do De Anima é possível entrever resquícios de uma tradição precedente, ainda mais fácil é observar esses traços de herança em outros tratados de Aristóteles nos quais se faz uso do termo

\footnotetext{
${ }^{3}$ Segundo Lefebvre $(1997,41)$, a antecipação, observada no De Anima, dos conceitos de imaginação e representação é a causa do interesse, por parte dos historiadores da filosofia, pelo tema da phantasía.
} 
"phantasía". Este trabalho, pois, visa a preencher uma lacuna quanto à interpretação de trechos em que surgem sentidos desviantes da palavra - desviantes, claro, relativamente ao sentido mais estudado pela maior parte dos aristotelistas cujas trabalhos puderam ser contemplados ao longo do desenvolvimento desta pesquisa. Confronta-se, assim, uma ocorrência do De Sensu com obras do filósofo localizadas fora da alçada de sua psicologia - em particular, obras voltadas para o estudo de fenômenos celestes. Também considerou-se apropriado lançar mão da análise de um estudo empreendido na escola peripatética o qual, no passado, atribuiu-se erroneamente a Aristóteles - o De Coloribus, obra voltada para o objeto próprio da visão -, a fim de avaliar com maior precisão o quanto o sentido não psicológico de phantasía estava arraigado no vocabulário do filósofo.

A primeira etapa do itinerário a ser percorrido abaixo consiste no estudo das tendências e propostas interpretativas na literatura secundária. Nesta parte, mostra-se como o debate sobre a phantasía aristotélica se desenrola em torno das ideias de imagem e de sensação, apresentando-se tanto as propostas que buscam reduzir o conceito à ideia de imaginação quanto aquelas que se esforçam por afastá-lo da noção de imagem interna. Ainda nesta primeira parte, são encetadas algumas considerações sobre a conexão entre phantasía e aparência em geral, bem como sobre a importância da ideia de movimento intrapsíquico para se compreender cada um dos fenômenos diversos aos quais o termo sob exame remete.

Na segunda etapa, empreende-se o estudo dos sentidos não psicológicos do termo "phantasía", tomando-se como ponto de partida a ocorrência da palavra no De Sensu et Sensibilibus, um dos tratados que compõem os Parva Naturalia, conjunto de pequenas obras cujo propósito é desenvolver temas específicos já anunciados no $D e$ Anima. A fim de compreender a passagem do De Sensu, lança-se mão da análise de dois tratados cosmológicos de Aristóteles - De Caelo e Metereologica -, bem como do De Coloribus. Após se constatar com segurança o sentido não psicológico capaz de ser assumido pelo termo "phantasía", procede-se à demonstração da relevância filosófica de tal sentido, a partir de sua conexão com as ideias de evidência, aparecimento, fenômeno e manifestação.

$\mathrm{Na}$ terceira e última etapa do itinerário, é desenvolvida uma análise filosóficosemântica das formas vocabulares do De Anima e um estudo do conceito de phantasía no terceiro livro desse tratado. Frente a três hipóteses possíveis concernentes ao problema da relação da phantasía Aristotélica com as tradições precedentes - ruptura 
total, resquício ínfimo de herança e coexistência entre inovação e herança arraigada -, opta-se por essa última, tendo-se como base da escolha a indiciossiabilidade entre a ideia de phantasía e a noção de movimento intrapsíquico. A força desse vínculo fica evidente a partir da relação entre o termo "phantasía" e certas expressões utilizadas no De Anima, bem como a partir do estudo das descrições enunciadas no terceiro capítulo dessa obra à luz dos Segundos Analíticos e dos Tópicos.

A organicidade do trabalho manifesta-se por duas vias, a bem dizer, o foco em um único item lexical ao longo dos três capítulos e o intuito, sempre presente, de inserir Aristóteles em um diálogo com alguma tradição que o precede, seja a tradição platônica, seja a tradição mais ampla dos falantes e escritores de língua helênica. A abordagem aqui desenvolvida difere, pois, daquela empregada em comentários cujo objetivo é elucidar o funcionamento da phantasía na viabilização do conhecimento ou da decisão racional $^{4}$. Entende-se que tais comentários, apesar de legítimos, geralmente pressupõe uma noção já elucidada de phantasía ou limitam-se a descrever os mecanismos de um fenômeno cuja definição ainda está por ser enunciada. Pretende-se, com o presente esforço interpretativo, resolver a questão dos diversos sentidos atrelados ao termo "phantasía", e não fornecer mais uma teoria sobre o modus operandi de apenas um de seus referentes, a qual versa sobre os fatos relacionais de um único fenômeno e termina, assim, por ignorar todo o restante da constelação de significados vinculada ao termo. Isso não quer dizer, todavia, que as conclusões aqui expressas não possam vir a auxiliar na elucidação do modo como a phantasía aristotélica funciona na efetivação do conhecimento teórico e da ação racional ou dos mecanismos de sua gênese a partir da sensibilidade. Tal auxílio, porém, seria um subproduto da realização do objetivo principal, disponível a quem se propuser a determinar o real papel desempenhado pela phantasía nos âmbitos epistêmico e prático.

\footnotetext{
${ }^{4}$ Dentre esses trabalhos, pode-se mencionar Schofield (1999) - sobre a relação entre phantasía e sensibilidade -, Frede (1999) - sobre a relação entre phantasía e conhecimento -, Nussbaum (1985) sobre a relação entre phantasía e ação -, Noel (1997) - sobre a relação entre phantasía e phrónesis -, Annas (1999) - sobre a relação entre phantasía e memória -, Levi (1964) - sobre as consequências epistemológicas da abordagem aristotélica da phantasía - e Caston $(1988 ; 1997)$ - sobre a relação entre phantasía e conteúdos mentais. Outros autores, como Bundy (1927), González (1974) e O’Gorman (2005) escreveram sobre a função da phantasía na arte da retórica. Kalaïtzidis $(1991,8)$ escreve: "A maioria dos estudos consagrados à imaginação em Aristóteles trata principalmente da relação entre imaginação e pensamento, assim como da relação entre imaginação e sensação, em detrimento dos outros aspectos do problema." O helenista português Eudoro de Sousa, apesar de reconhecer a pluralidade semântica do termo "phantasía", só a menciona como a faculdade intermediária entre sensação e pensamento (2012, 191). Larrière (1984) aborda a diferença entre phantasía deliberativa e phantasía sensitiva, também por esse viés relacional.
} 
Em um sentido mais amplo, intenta-se, com este trabalho, agregar mais um exemplo que corrobore a tese segundo a qual são constantes, na filosofia de Aristóteles, tanto a superação quanto a conservação da tradição precedente. A inovação, no estilo de filosofar do Estagirita, sempre vem calcada em elementos herdados do platonismo ou de seu ambiente cultural. Obviamente, fundamentar de modo adequado tal afirmação requer um espaço que extrapola os limites desta pesquisa, bem como uma variedade de temas e documentos não comportada pelo seu escopo. Contudo, considerar-se-á um resultado de bom tamanho caso os argumentos abaixo defendidos puderem demonstrar que o uso do termo "phantasía" por parte de Aristóteles é muito mais conservativo do que normalmente se pensa.

As traduções dos trechos citados, tanto de obras antigas quanto de comentários, são, sem exceção, de autoria própria. 


\section{CAPÍTULO I: STATUS DA QUESTÃO}

\section{TENDÊNCIAS DE INTERPRETAÇÃO}

Victor Caston, em seu capítulo Aristotle's Psychology, identifica duas tendências no tratamento do conceito de phantasía dispensado por comentadores hodiernos, as quais emergem a partir do grau de importância atribuído à relação do conceito com a ideia de imagem mental $(333,2003)$. Segundo o autor, a interpretação tradicional, impulsionada pelo alto nível de detalhamento conferido por Aristóteles ao último terço do De Anima III, 3, para o foco na representação ligada ao conteúdo perceptual, foi construída em termos de imagens mentais ${ }^{5}$ - fato que remete, afirma Caston, a um período anterior à ascensão do behaviorismo, quando a introspecção ainda dominava os debates em psicologia (ibid., 332-333). Interpretados nessa linha, os phantásmata são representações visualizadas internamente de objetos percebidos, i.e., eles são objetos de um ato mental interno, assemelhando-se subjetivamente às coisas percebidas - Caston também nota que a interpretação do phántasma como uma "cópia" menos vívida de sensações remete ao conceito de imaginação encontrado no empirismo britânico (ibid., 333).

\subsection{A não necessidade do conceito de imagem}

Dentre os trabalhos que negam a necessidade do vínculo entre phantasía e imagem mental, encontra-se o influente artigo de Malcolm Schofield, Aristotle on the Imagination. Schofield parte do fato de Aristóteles não restringir as aparências atribuídas à faculdade da phantasía aos casos óbvios de criação de imagens mentais, incluindo, nas linhas dedicadas à análise do conceito, exemplos de sensação direta (1992, 250). Ao enfatizar a receptividade de Aristóteles à linguagem comum, na qual a expressão "parece que" é utilizada em contextos de vigília, quando a certeza não acompanha o ato de perceber (CASTON, 2003, 333), Schofield identifica um aparecer (phaínesthai) cético, cauteloso ou não comprometedor referente à verdade de sensações e semissensações (SCHOFIELD, 1992, 252). Sua tese apresenta a phantasía como uma capacidade que possibilita "experiências sensórias não paradigmáticas", de sonhos à

\footnotetext{
5 Nussbaum $(1985,224)$ identifica duas características atribuídas à phantasía aristotélica pelas interpretações centradas na ideia de imagem: “(1) A imaginação envolve, em todos os casos, imagens que representam em virtude de alguma similaridade; (2) A imaginação sempre envolve dois processos logicamente (mas não necessariamente temporalmente) distintos: a posse de uma imagem (produzida ou, de algum modo, impressa), e sua inspeção ou contemplação.”
} 
interpretação de dados sensórios indistintos (ibid., 253). Contudo, o autor não exclui a criação de imagens mentais como um dos fenômenos proporcionados pela capacidade afinal, os dois critérios oferecidos por Aristóteles para distingui-la da opinião ajustamse perfeitamente ao conceito de imaginação ${ }^{6}$, e negá-lo seria, nas palavras do comentador, "perverso" (ibid., 253-254) -, mas, ao contrário, assimila o ato como um tipo de experiência sensorial não paradigmática (ibid., 253). Desse modo, a ideia de imagem mental é afastada do centro da questão, persistindo como apenas uma das espécies de um gênero cuja caracterização é feita não a partir da imagem, mas da sensação indistinta.

Outro trabalho pioneiro na esteira da crítica à interpretação a qual vincula de modo necessário o conceito de phantasía com o de imagem mental é o ensaio de Martha Nussbaum sobre o papel daquela na teoria aristotélica da ação, incluso em sua tradução do De Motu Animalium. Assim como Schofield, Nussbaum enfatiza a pluralidade de experiências relacionadas com o verbo "phaínomai" e nega a existência de uma teoria canônica da phantasía em Aristóteles (NUSSBAUM, 1985, 222)7. Contudo, sua abordagem foca no papel positivo desempenhado pela phantasía nas explicações destinadas ao fenômeno da ação, e, consequentemente, na relação estabelecida entre phantasía, desejo (órexis) e intelecto (nóesis) nas passagens "negligenciadas" De Anima III, 9-11, bem como no De Motu Animalium (ibid., 221). Segundo a autora, a abordagem de Aristóteles acerca da phantasía nos contextos de ação e sua explícita referência a phaínetai apresentam a phantasía como uma faculdade para perceber os objetos como certos tipos de coisas (ibid., 255) - no caso, como algo a ser perseguido ou evitado (CASTON, 2003, 333). É atribuída, assim, uma clara função interpretativa à capacidade $^{8}$ : ao aparecer para uma criatura, o objeto é simultaneamente selecionado, delimitado, organizado e interpretado pela phantasía, cujo exercício encontra-se pressuposto em todo ato da sensibilidade ${ }^{9}$ (NUSSBAUM, 1985, 269). Schofield (1992,

\footnotetext{
${ }^{6}$ Sobre o conceito de imaginação, vide Sparshott (1990).

${ }^{7}$ Comparar com a posição de Schofield $(1992,257)$, segundo a qual o conceito de phantasía não possui uma unidade bem estabelecida (“Aristotle's phantasía is a loose-knit, family concept").

${ }^{8}$ Nussbaum chega até a afirmar a primazia do interesse, por parte de Aristóteles, nesse aspecto da faculdade, em detrimento da ênfase nas imagens: “A evidência indica que seu interesse básico é em como as coisas no mundo aparecem para as criaturas vivas, como o que as criaturas veem seus objetos. Por vezes ele fala de imagens enquanto sentidos evanescentes que são como as coisas que elas representam. Ocasionalmente, estas são caracterizadas como phantásmata. Mas a evidência não nos permite identificar imagens em toda passagem." (NUSSBAUM, 1985, 255).

${ }^{9}$ A interpretação de Nussbaum não é isenta de críticas. A atribuição à phantasía de um escopo tão largo peca no que se refere às evidências textuais disponíveis, indicando um afastamento do conceito básico: "Isto certamente vai além da concepção básica de phantasía: Nussbaum, aqui, atribui à phantasía um
} 
260) também lhe atribui um papel interpretativo em relação aos dados sensoriais, mas, diferentemente de Nussbaum, que enfatiza tal papel nos contextos de tomada de ação, foca nos casos de sensação indistinta - o julgamento segundo o qual o objeto visto de modo impreciso é um homem indicaria o ato interpretativo da imaginação, o qual representa um ir além da imediatez do dado sensorial. Não obstante essa diferença, ambos os autores negam a necessidade do vínculo entre os conceitos de phantasía e imagem em prol de uma apreciação da pluralidade de fenômenos relativos àquele, além de enfatizarem sua virtude interpretativa, sem com isso excluir a possibilidade de referências ocasionais a imagens genuínas ${ }^{10}$.

\subsection{Segunda tendência: a necessidade do conceito de imagem}

A segunda tendência, na qual é defendida a coerência geral da teoria de Aristóteles acerca da phantasía, deve sua motivação, afirma Caston (2003, 333), ao ressurgimento, ocorrido no último quarto do séc. $\mathrm{XX}$, do interesse em teorias representacionais da mente. Dorothea Frede, em seu artigo The Cognitive Role of Phantasia in Aristotle, aceita a interpretação tradicional que trata os phantásmata como imagens genuínas (FREDE, 1992, 285) e atribui à phantasía duas funções principais, indispensáveis para o exercício da cognição: a síntese e retenção das sensações, e a

papel em lugar algum explícito nos textos." (MOSS, 2012, 54). Por "concepção básica” entende-se o conjunto de características consistente e explicitamente atribuídas por Aristóteles à phantasía, o qual fornece a ideia de uma capacidade para se experimentar um fenômeno semelhante à sensação de um objeto qualquer, mas que não é causado por um contato sensorial direto com este - em outras palavras, segundo sua concepção básica, a phantasía seria a capacidade para apresentar ao indivíduo algo anteriormente captado sensorialmente (ibid., 53). Uma justificação para as abordagens especulativas aquelas que extrapolam o conceito básico ao supor que o papel da phantasía no processo de locomoção tem a ver com a adição de algum conteúdo àquilo que é apreendido através da faculdade sensitiva poderia apelar, naturalmente, para a falta de clareza no tratamento dispensado por Aristóteles ao papel da phantasía na locomoção (ibid., 56); contudo, nem toda abordagem referente à phantasía necessita extrapolar o conceito básico a fim de explicar certas funções: "Através da phantasía, um agente pode ter uma experiência psicologicamente semelhante à percepção de algum objeto particular, mesmo quando tal objeto não está lá para ser percebido, e esse é o próprio fato que explica por que o agente "faz coisas de acordo com" as phantasíai, ou seja, por que ele age com base nelas. A afirmação de Aristóteles é que a phantasía contribui para a ação animal apenas pela preservação e reprodução de percepções, não pela interpretação, síntese ou em outros modos que vão além do que a percepção por si só poderia fazer, estivesse ela sendo de fato exercida sobre o objeto apropriado no momento." (ibid., 57). Na visão de Moss, portanto, a concepção básica de phantasía pode, de modo consistente, explicar o processo de locomoção sem mencionar qualquer ato interpretativo ou de síntese, os quais, de um ponto de vista puramente textual, não possuem qualquer respaldo.

10 “Aristóteles, em III, 3, como alhures, direciona sua atenção para uma ampla variedade de fenômenos sob a rubrica de "phantasía", fenômenos que ele nem sempre distingue claramente. A análise em termos de sentido evanescente no final do capítulo não ajusta-se à discussão em sua totalidade. A melhor via para o intérprete parece ser não livrar-se das inconsistências, ou tentar fazer com que tudo se ajuste com a passagem aparentemente mais técnica, mas permitir que a phantasía Aristotélica tenha o amplo escopo que evidentemente possui alhures e reconhecer a diversidade dos fenômenos em questão." (NUSSBAUM, 1985, 225). Segundo Nussbaum, portanto, a ideia de uma phantasía ligada aos subprodutos da atividade sensorial não é capaz de lidar com a ampla variedade de fenômenos mencionados por Aristóteles. 
aplicação de pensamento aos objetos da sensibilidade (ibid., 283) ${ }^{11}$. Segundo a autora, entre as faculdades intelectiva e sensitiva existe uma lacuna intransponível ${ }^{12}$, a qual há de ser preenchida justamente pela imaginação, através das funções já mencionadas. Não obstante a menor precisão das imagens comparativamente à das sensações diretas, elas, possuindo uma maior duração e possibilitando a permanência dos dados sensoriais ${ }^{13}$, são responsáveis pelo fornecimento de um retrato padronizado dos estados de coisa em geral - em resumo, Frede posiciona a phantasía no centro do processo de indução, pois esta exige um apanhado de impressões sensoriais que fornece ao intelecto os fenômenos a serem explicados e preservados (ibid., 193). Sua interpretação, apesar de possuir um caráter notadamente especulativo - como reconhecido pela própria autora - em virtude da brevidade do tratamento dispensado à phantasía no corpus, possui o mérito, pelo menos à primeira vista, de coadunar com as ideias de Aristóteles acerca das faculdades envolvidas no processo de aquisição de conhecimento. Apesar de não haver evidência textual direta, em Aristóteles, sobre um escopo tão amplo da phantasía, as considerações de Frede não parecem apresentar inconsistências com aquilo que o filósofo tacitamente aceitaria, caso sua exposição houvesse sido construída de forma mais detalhada.

Deborah Modrak, em seu livro Aristotle: The Power of Perception, aceita, como Frede, a identificação dos phantásmata com imagens, inserindo-se, assim, na contracorrente da tendência iniciada por Nussbaum e Schofield (CASTON, 2003, 333). A autora, afirmando haver na psicologia de Aristóteles um esforço para minimizar tanto quanto possível o postulado de novas faculdades anímicas além das já consideradas básicas e indispensáveis, sustenta que a phantasía, uma capacidade cognitiva mais avançada, é analisada dentro dos limites dos cinco sentidos especializados e estruturada de acordo com estes, de modo que a faculdade perceptiva apresentaria uma unidade instrumental ligada não apenas à sensação direta, mas capaz de produzir qualquer fenômeno cuja ocorrência requer representações sensoriais (MAUDLIN, 1990, 306). Nessa interpretação deflacionária da faculdade da phantasía, esta, na identidade interna com as sensações, define-se como uma consciência voltada para os conteúdos

\footnotetext{
${ }^{11}$ Joyce $(2003,369)$ sustenta uma visão parecida, ao tratar a phantasía como uma faculdade interpretativa utilizada na percepção de particulares.

${ }^{12}$ Intelecto e sensação encontram-se estreitamente confinados a seus respectivos objetos: aquele pensa apenas o não sensível, i.e., as formas inteligíveis, enquanto aquela se limita ao captado pelos sentidos nos instantes em que perante estes os objetos encontram-se presentes (FREDE, 1992, 290).

${ }^{13}$ Dada a restrição da sensibilidade ao momento da captação do objeto em sua presença, as sensações "em sentido amplo" já pressupõem o produto da phantasía (FREDE, 1992, 291).
} 
perceptuais dada em condições diversas daquelas que conduzem à sensação verídica (MODRAK, 1987, 82) - seu produto, dessa forma, difere-se do da faculdade sensitiva a partir de condições externas, das circunstâncias informativas ligadas a seu surgimento.

O terceiro representante da linha interpretativa na qual não é negada a coerência da teoria de Aristóteles sobre a phantasía citado por Caston é Michael Wedin, autor da obra Mind and Imagination. Seu trabalho apresenta um afastamento em relação a Frede e Modrak, na medida em que, ao interpretar a abordagem de Aristóteles em termos cognitivistas - o primeiro de seus objetivos principais é, de fato, a defesa de que a abordagem de Aristóteles acerca da mente pode ser apropriadamente interpretada como cognitivista (WEDIN, 1988, xi) ${ }^{14}$-, a phantasía não representa uma faculdade genuína

não haveria, segundo o comentador, um ato completo equivalente a imaginar algo (ibid., 55) -, ao contrário, por exemplo, da sensação, mas um sistema de representações internas que auxilia outras faculdades - os phantásmata, aqui, em vez de serem compreendidos como objetos da phantasía ou imagens evanescentes, são abordados como estados corporais físicos, caracterizados por um conteúdo adquirido em virtude da similaridade com certo objeto, juntamente com um papel bem definido dentro do sistema cognitivo (CASTON, 2003, 333).

\section{UM PRIMEIRO PROBLEMA: A MULTIPLICIDADE DOS FENÔMENOS}

O afastamento entre phantasía e imagem mental, motivado pela pluralidade de exemplos referentes a tipos de aparência cuja interpretação em termos imagéticos tornase problemática - como, afinal, explicar, a partir de uma ou mais imagens, a aparição relativa à magnitude do sol a quem da Terra o observa? -, pressupõe a univocidade deliberada por parte de Aristóteles no De Anima III.3. Excluída a possibilidade de reconstruir em termos de imagem mental o modo como objetos externos aparecem, duas alternativas restam quanto ao tratamento da tensão: ou se aceita que Aristóteles está a utilizar ali o termo "phantasía" em mais de um sentido, ou se lhe nega a intenção de definir a phantasía como uma faculdade responsável por produzir imagens (SCHEITER, 2012, 252). Ambas as alternativas, sob um primeiro olhar, parecem ir de encontro à evidência textual.

\footnotetext{
${ }^{14} \mathrm{O}$ segundo objetivo divide-se em duas partes: a primeira consiste precisamente naquilo que permite incluir Wedin na tendência contrária à dos trabalhos pioneiros de Nussbaum e Schofield - fornecer uma explicação da teoria aristotélica da phantasía como uma abordagem coerente em seu interior; a segunda, apresentar, nessa explicação, a phantasía como uma faculdade não genuína (WEDIN, 1988, xi).
} 
A primeira delas, ao supor a pluralidade de usos feitos por Aristóteles, torna misteriosa as razões que o levam, na abordagem detalhada do De Anima III.3, a lançar mão de exemplos de casos ligados a fenômenos tão diferentes entre si. Na falta de uma noção unificada capaz de englobar a multiplicidade de aparências possíveis - da mais sensitiva à mais imaginativa, da mais enganadora à mais verossímil -, como conciliar um esforço voltado para a teorização, expresso na especificidade do contexto e na clara intenção de postular uma função diferenciada, com a ambiguidade manifesta através do uso de um mesmo termo para designar fenômenos que, em essência, nada têm a ver uns com os outros?

A segunda alternativa, pela qual opta a maioria dos comentadores, ao pressupor a conexão entre a faculdade da phantasía e cada tipo peculiar de aparência ${ }^{15}$, conexão essa indicativa da consistência interna da abordagem de Aristóteles, vê-se forçada a apontar o que unifica as diversas espécies de aparição sem deixar de reconhecer suas manifestas particularidades. Tal tarefa revela-se notadamente complexa, uma vez que entre a produção de imagens intrapsíquicas - ato sem dúvida alguma atribuído pelo filósofo à phantasía, sendo tal ato indispensável ou não para caracterizá-la - e a magnitude visível de um objeto distante parece haver um abismo de causas exclusivas a cada fenômeno $^{16}$. Não se trata necessariamente de empreender uma redução de um nos termos do outro - por exemplo, de explicar a aparência visível das coisas a partir da

${ }^{15}$ Scheiter $(2012,252)$ afirma: "A phantasía deve explicar as aparências, como por que o sol parece ser do tamanho de um pé, apesar de acreditarmos que ele seja bastante grande." Schofield (1992, 273, n. 52), em seu já citado artigo pioneiro, considera óbvio o envolvimento de uma faculdade unificada da imaginação nos diversos fenômenos mencionados no decorrer da análise de Aristóteles sobre a phantasía. ${ }^{16} \mathrm{O}$ problema da multiplicidade de fenômenos envolvidos nas passagens dedicadas ao estudo da phantasía é mencionado por Jessica Moss em seu recente livro intitulado Aristotle on the Apparent Good: Perception, Phantasia, Thought and Desire (2012, 50-51): "A dificuldade em fornecer uma explicação unificada da phantasía provém do fato de que Aristóteles a torna responsável por uma ampla variedade de fenômenos psicológicos, ao mesmo tempo em que a define de um modo tal que essa amplitude resulta misteriosa. Nas passagens onde ele fornece definições de phantasía, ele a caracteriza como um parente próximo da percepção (aísthesis) e enfatiza seu papel na percepção não padrão e no erro perceptual. Isto torna inteligível seu papel nas ilusões perceptuais e sem dúvida também nos sonhos e na memória. $\mathrm{O}$ papel que Aristóteles atribui à phantasía em outras passagens, contudo, é muito amplo: ela é necessária para qualquer pensamento locomoção. Essa miscelânea de papéis conduziu a uma notável variedade de interpretações da phantasía, e alguns declaram ser vã a procura por uma explicação unificada. Por que a mesma capacidade pela qual nós experimentamos sonhos e pós-imagens ter um papel crucial em todo pensamento [...] e na movimentação de um local para outro?" Moss, contudo, apesar de chamar a atenção para o grande número de fenômenos psíquicos ligados ao conceito, só problematiza tal multiplicidade por conta do papel exercido pela phantasía no processo intelectivo e na locomoção. Em outras palavras, a comentadora não considera aporética a inclusão, em um mesmo conjunto, de fenômenos tão diversos como a produção de imagens e as sensações errôneas; apenas a participação da phantasía nos processos de pensamento e locomoção tornaria complexa uma abordagem unificada. Todavia, a dificuldade de se elaborar uma explicação capaz de abranger tamanho pluralismo evidencia-se antes mesmo de tal participação ser considerada. 
atividade imaginativa ou vice-versa -, mas de referir a totalidade desses fenômenos a uma única função anímica sem deixar de preservar a consistência da interpretação. Isso significa não somente encontrar algo compartilhado por cada fenômeno ao qual Aristóteles faz menção em suas observações acerca da phantasía, mas também de demonstrar a necessidade desta para se obter uma explicação satisfatória desses fenômenos entre si tão diversos - i.e., deve-se tornar manifesta a impossibilidade de explicar algum deles puramente em termos de apreensão sensorial, junto com o fato de Aristóteles estar consciente da insuficiência de uma redução que dispensa a atividade da phantasía.

\subsection{A abordagem não reducionista}

Um exemplo já citado do esforço de remeter a pluralidade de casos presente nas linhas dedicadas ao estudo da phantasía a uma única faculdade psíquica é a abordagem de Schofield, para quem a característica essencial desta é a capacidade de habilitar o ente a ter as ditas “experiências sensórias não paradigmáticas". Nesse sentido, o comentador reduz a imagem em termos dessas sensações divergentes do padrão fornecido pela assimilação dos objetos sensíveis próprios, as quais se assemelham de certa maneira ao paradigma sensorial sem compartilhar a totalidade de seus traços, dando origem aos usos céticos do verbo phaínomai (SCHOFIELD, 1992, 253). Tal maneira de interpretar extrai suporte da análise causal da phantasía feita por Aristóteles - a qual, ao enfatizar o caráter sensório de seus produtos e definindo-os em termos de sensibilidade, efetua uma espécie de redução - e possui, como bem nota Schofield, o mérito de tornar inteligível as linhas finais do DA III.3. O exercício da phantasía encontraria sua razão de ser precisamente nas lacunas da sensibilidade (ibid., 261), sendo a existência de tais lacunas um elemento presente em todos os fenômenos mencionados no estudo daquela - de fato, a lacuna do sensível expressa-se tanto nas situações de criação de imagens, quando o objeto real se encontra ausente, como nos casos de sensação indistinta.

Schofield é contra atribuir à phantasía aristotélica um escopo demasiadamente largo - ela não estaria presente, segundo o comentador, em toda atividade sensitiva -, utilizando como evidência o fato de Aristóteles não mencioná-la ao longo do De Anima II como um instrumento essencial para a análise da sensação (ibid., 261). Com efeito, a falta de suporte textual direto testemunha contra a presença necessária da phantasía em todos os atos da sensação - o fato de Aristóteles não a introduzir como um componente 
indispensável para o funcionamento da faculdade sensitiva, sem explicar pormenorizadamente seu suposto modus operandi dentro dos mecanismos desta, entra em conflito com o alto nível de rigor de sua análise ${ }^{17}$ exposta no De Anima II. Sem dúvida, tivesse a phantasía um papel mais fundamental - i.e., fosse ela uma précondição para o exercício do ato sensitivo -, o filósofo haveria de detalhar seu já pormenorizado estudo da faculdade sensitiva de modo a incluí-la nas tantas descrições minuciosas lá encontradas. Todavia, não apenas a omissão do termo "phantasía" na análise funcional da sensação não há de passar despercebida, mas também se deve levar em conta que dele não é feito qualquer uso no tratamento dispensado aos sensíveis comuns e incidentais ${ }^{18}$.

\subsection{Uma tentativa de redução}

A sensação do sol enquanto dotado da magnitude de um pé refere-se certamente a um objeto sensível comum (SCHEITER, 2012, 274), cuja apreensão pode se dar por uma pluralidade de sentidos. As observações de Aristóteles acerca da sensação comum - em especial, a referente a seu menor nível de precisão - mostram-se adequadas para lidar com os casos de aparências visuais falsas; como consequência, o estabelecimento do vínculo entre a sensação enganosa quanto ao real tamanho do sol e a phantasía parece, no mínimo, supérflua. A partir do expresso no De Anima II, fica claro que a discriminação da magnitude de algo se dá através da faculdade sensitiva, possuindo esta, ademais, em seu modo de relacionar-se com objetos sensíveis comuns, abertura ao erro. Contudo, nem sempre a completude da análise da faculdade sensitiva relativamente à explicação dos casos da aparência peculiar dos sensíveis comuns é enfatizada na literatura secundária. Schofield, por exemplo, atribui à phantasía a

\footnotetext{
${ }^{17}$ Segundo Benardete $(1975,611)$, a precisão almejada por Aristóteles manifesta-se no uso de exemplos retirados da matemática.

${ }^{18}$ Moss $(2012,54)$ também percebe a suposta autossuficiência da faculdade sensitiva na captação dos sensíveis comuns e incidentais: "Independentemente de ele fornecer ou não uma explicação de como isto é possível, Aristóteles certamente fala como se a percepção por ela mesma, sem ajuda da phantasía (ou do pensamento), pudesse perceber todas as três classes de perceptíveis. [...] 'Isto é bebida', diz a percepção, a phantasía ou o pensamento (701a32-33). Também é implicado (inconclusivamente) por uma passagem a qual parece caracterizar a phantasía como "um movimento que surge da atividade [...] desses [três tipos de] percepção" (DA, 428b25-429a2): se a phantasía é o que surge da percepção dos perceptíveis comuns e incidentais (bem como dos próprios), então ela não está envolvida, presumivelmente, na própria percepção. [...] Se a phantasía funciona simulando a percepção, então deve haver algum conteúdo já contido na percepção para a phantasía simular - o conteúdo da percepção por si só deve ser muito semelhante ao conteúdo da phantasía."
} 
discriminação do tamanho do sol, sem considerar a tensão criada por tal passo interpretativo com o anteriormente estabelecido por Aristóteles ${ }^{19}$.

O exemplo da magnitude do sol é, não surpreendentemente, a principal evidência contra a interpretação da phantasía em termos de imagem (SCHEITER, 2012, 272). Todavia, seu enquadramento no escopo dessa função anímica, do ponto de vista da negação da essencialidade da imagem para caracterizar todos os casos de fenômenos exemplificados no decorrer do estudo da phantasía, mostra-se supérfluo frente ao expresso na abordagem de Aristóteles relativa aos objetos sensíveis comuns, além de deixar intocados os problemas da ausência de menção àquela no De Anima II e da relevância dos exemplos, no terceiro capítulo do livro III, a instâncias de sensação visual. Qual seria, assim, a melhor maneira de conciliar phantasía e sensações não paradigmáticas, bem como suas respectivas abordagens?

Até então, entreviram-se dois caminhos: admitir a pluralidade semântica do termo "phantasía", negando qualquer pretensão unificadora por parte de Aristóteles, ou excluir a necessidade de vincular seu significado à ideia de imagem. Contudo, ao invés de abolir de antemão o vínculo essencial entre phantasía e imagem, não seria possível enveredar por uma terceira via, fundada na redução imagética das sensações falsas e indistintas?

Scheiter, na contracorrente da tendência contemporânea, aceita a essencialidade da imagem para o significado do conceito aristotélico de phantasía, interpretando em termos imagéticos todas as instâncias de fenômeno mencionadas no contexto de seu tratamento, inclusive aquelas à primeira vista mais representantes de uma atividade sensorial. A partir do conceito de phantasía enquanto uma função responsável por preservar dados sensórios apreendidos em instantes passados (ibid., 2012, 269), em conjunto com a ideia - proveniente da teoria aristotélica da reminiscência - segundo a qual as imagens conservadas no órgão sensorial primário são capazes de colocar em movimento outras imagens (ibid., 2012, 271), a comentadora tenta proceder à interpretação das sensações não próprias sem excluir o papel dos phantásmata em sua ocorrência. Dada a equivalência, em termos de movimento, entre sensação e phantasía, seria possível inferir a capacidade do ato da sensibilidade, ocorrido na presença do

\footnotetext{
${ }^{19}$ A aparência do sol enquanto tendo o tamanho de um pé seria o resultado do julgamento da faculdade responsável pela ocorrência de phantásmata, a qual, nesse caso específico, é frequentemente contradita pelo julgamento de outra função anímica (SCHOFIELD, 1992, 268). Os Comentários do Colégio Conimbricense da Companhia de Jesus também ignoram a mencionada tensão: "Na verdade, a imaginação percebe, por exemplo, que o Sol mede um pé, e segundo a verdadeira opinião, que acolhe do matemático, considera o Sol maior do que a massa da Terra." $(2010,441)$.
} 
objeto, em incitar as imagens armazenadas. Tendo em vista o movimento da imagem engatilhado pela sensação, a qual lhe é fenomenologicamente igual, haveria, segundo Scheiter, uma combinação não inferencial e não deliberada de atividade sensória e phantasía nos casos de sensação por acidente e dos sensíveis comuns (ibid., 274).

Nos casos de sensação acidental, a sensação relativa a um objeto em presença colocaria em movimento, afirma Scheiter (ibid., 271), a imagem que lhe é mais próxima em semelhança, produzindo-se, assim, uma combinação de ambas no órgão sensorial primário. Esse processo automático, no qual imagens unificadas são postas em movimento por sensações, formando com elas um composto de phantasía e sensação em presença, explicaria a própria possibilidade de objetos sensíveis acidentais serem percebidos, bem como o porquê de o erro vir por vezes associado à sua apreensão ${ }^{20}$ (ibid., 272). A redução imagética das sensações por acidente é efetuada, portanto, a partir da equivalência entre "x parece ser y" e "a sensação em presença de x assemelhase à imagem de y" (ibid., 275), sendo x algo percebido de modo impreciso no tempo presente, e y uma imagem armazenada correspondente a um objeto o qual esteve, em instantes passados, múltiplas vezes ao alcance dos sentidos. Seria esta, pois, a estrutura do aparecimento das coisas como semelhantes a algo ${ }^{21}$.

A redução efetuada por Sheiter, ao menos no tocante ao modo como imagens podem vir a ter um papel ativo na ocorrência de aparições ligadas a objetos sensíveis acidentais, constitui, sem dúvida, uma manobra interpretativa engenhosa, uma vez que fornece uma possível explicação do modus operandi da phantasía nos casos de aparecimento em presença sem incorrer em inconsistências ao entrelaçar as várias noções a princípio envolvidas no fenômeno (sensação, phantasía, movimento, igualdade fenomenológica). Apesar de não extrair qualquer suporte direto das considerações do De Anima II acerca da sensação acidental, a abordagem de Sheiter seria, à primeira vista, uma forte candidata para preencher as aparentes lacunas do texto de Aristóteles sem abandonar a pressuposição de sua consistência interna.

Contudo, apesar de a redução acima descrita apresentar-se como um bom exemplo de exercício interpretativo, ainda resta averiguar se é possível efetuá-la para os

20 "Quando Aristóteles diz que aparências são frequentemente falsas, ele quer dizer que nossas experiências perceptuais (as quais são combinações da percepção presente de perceptíveis especiais e da imagem unificada que ela invoca) não correspondem ao modo como as coisas realmente são." (ibid., 275).

${ }^{21}$ Sheiter chama a atenção para o caráter não necessariamente contemplativo ou consciente de tal ato psíquico (ibid., 275), entrando em contraste com a interpretação de Schofield acerca das sensações imprecisas, a qual admite a abertura para o exercício imaginativo consciente nos casos em que um objeto percebido de modo impreciso é visto como semelhante a algo familiar (SCHOFIELD, 1992, 260). 
casos de sensação relativa a objetos comuns a mais de um sentido. Scheiter defende que a combinação de sensações em presença e imagens unificadas ocorre não apenas quando se percebem sensíveis por acidente, mas também quando há apreensão dos objetos capazes de ser assimilados por uma pluralidade de sentidos. De acordo com seu raciocínio, a condição necessária para que algo pareça ser dotado de determinada magnitude é a semelhança entre a sensação presente, relativa ao tamanho do objeto perante o indivíduo, e certas sensações tidas no passado, referentes ao mesmo tamanho observável, mas que acabaram por corresponder à real dimensão dos objetos (ibid., 274).

A redução imagética dos casos de assimilação dos sensíveis comuns efetua-se, na perspectiva de Sheiter, da mesma maneira em que é realizada a redução em termos de imagem para a sensação acidental. No aparecimento do sol enquanto possuindo o tamanho de um pé, imagens referentes a esse mesmo tamanho, armazenadas no órgão sensorial primário, seriam postas em movimento pela impressão sensória direta sobre o olho, causada pelo próprio sol, e formariam, junto com ela, uma combinação de phantasía e sensação. Ao perceber o sol como dotado da magnitude de um pé, o indivíduo compara a sensação em presença com outras sensações, cujo ato deu-se em momentos passados e as quais são através daquela evocadas (ibid., 274-275). Dessa forma, também a aparência dos sensíveis comuns reduzir-se-ia ao esquema "a sensação presente de x assemelha-se à imagem de y”.

Salvaguardaria a interpretação de Scheiter a essencialidade da imagem para a ocorrência de fenômenos sensoriais não paradigmáticos? Sua redução imagética da apreensão dos sensíveis por acidente constitui, como já observado, um esforço interpretativo a princípio consistente com a teoria aristotélica da alma, uma vez que não entra em conflito com a ideia ali contida de imagem, permanecendo fiel ao expresso nos textos primários (ou, ao menos, no intuito de adequá-los à explicação visada, distorcendo-os minimamente). Nele, preserva-se a conexão mais intuitiva entre imagem e sensação, a bem dizer, aquela encontrada no exercício da faculdade imaginativa voltado para a identificação de um objeto cuja vista dá-se apenas de maneira indistinta ao observador - Schofield, apesar de já haver apontado para essa conexão, não fornece uma descrição dos mecanismos pelos quais as imagens vêm a atuar no processo, tal como o faz Scheiter. O fenômeno anímico referido por expressões do tipo "isso parece um homem" certamente permite evidenciar o ato imaginativo necessário à sua constituição - caso não houvesse armazenada, na estrutura psíquica do indivíduo, uma 
imagem correspondente à ideia de homem, formada a partir da observação de muitos casos particulares, a aparência ligada ao sujeito que se encontra a certa distância jamais lhe ocorreria do modo como se manifesta a quem possui em si a mencionada imagem.

Apesar de Aristóteles não providenciar, em seus textos, uma descrição de como imagens viriam a atuar na ocorrência de sensações não paradigmáticas - os supostos vínculos entre as duas espécies de fenômeno estando, no plano puramente textual, limitados a menções concomitantes -, é fácil notar o papel da ação imaginativa no reconhecimento de objetos distinguidos sem a precisão das sensações dos objetos sensíveis próprios. Se fosse solicitado a dois indivíduos, por exemplo, a identificação de um mesmo objeto encontrado a uma distância considerável, cada um deles haveria de sugerir uma identidade de acordo com a imagem armazenada que mais se assemelha à coisa indistintamente vista - em casos assim, a possibilidade de o objeto vir associado a aparências diversas é evidente, visto que o conjunto de imagens armazenadas varia de indivíduo para indivíduo, ao menos no concernente a particulares. Dessa maneira, um pode ver Sócrates onde o outro vê Calias - Aristóteles não utiliza esse tipo de exemplo, limitando-se ao caso apreendido pela forma "isso parece um homem", nem considera a mencionada possível divergência na identificação do objeto visto sem clareza. Schofield (1992, 260) menciona outra possibilidade ligada à ação imaginativa - presente no ato de comparar e contrastar a coisa vista e com a aparência dos objetos familiares - nesse processo de identificação, a bem dizer, aquela segundo a qual o objeto a ser identificado manifesta-se em aparências diferentes ao mesmo indivíduo.

O papel da imagem revela-se claro no esforço de identificar objetos a distância, de modo que a redução imagética das sensações acidentais surge, a princípio, como uma alternativa possível. Contudo, resta averiguar se tal redução pode ser efetuada com sucesso para os casos de sensação dos objetos comuns, ou se estes são, ao contrário, irredutíveis a termos de imagem. Havendo a possibilidade de introduzir os produtos da imaginação na análise da sensação referente aos sensíveis comuns, angaria-se não apenas evidência para a leitura da phantasía aristotélica enquanto essencialmente vinculada ao conceito de imagem, mas também para a univocidade da noção no $D e$ Anima.

$\mathrm{Na}$ interpretação de Sheiter, para o Sol ser visto como medindo o tamanho de um pé - ou seja, para que ele pareça ser dotado dessa magnitude -, deve haver a similaridade entre a sensação presente e as imagens, provenientes de sensações passadas, relativas a objetos que de fato medem um pé (SCHEITER, 2012, 274). 
Todavia, uma consequência indesejada de tal redução dos sensíveis comuns a termos de imagem é que, não estando ainda armazenadas no órgão sensorial primário do indivíduo as imagens referentes a objetos dotadas da magnitude de um pé, o sol não lhe apareceria da mesma forma. Possuir essas imagens se torna, na leitura de Scheiter, condição sine qua non para o sol aparecer do modo como efetivamente aparece a quem o vê da Terra, o que exacerba o papel ativo daquelas; mesmo sendo óbvio, no caso de já haver imagens armazenadas, o ato de compará-las com a sensação presente do sol, é legítimo questionar se, em um nível mais primordial, são elas as reais geradoras da aparência. Tal leitura revela-se efetivamente controversa, uma vez que a sustentação, por parte de Aristóteles, da possibilidade de sensações distintas relativas à magnitude do sol em função dos estoques particulares de imagens armazenadas - uma ideia não expressa abertamente no artigo de Scheiter, mas a qual decorre de sua abordagem reducionista é improvável. De fato, poder-se-ia afirmar certa diferença no modo de se relacionar cognitivamente com o tamanho do sol - quem não possuir armazenada a imagem relativa à magnitude usual de um pé ainda não tem condição de, ao entrar em contato sensorial com aquele, exercer o ato comparativo -, o que não equivale a postular uma diferença entre os dados sensoriais primitivos em função da diversidade de imagens retidas. É difícil, senão impossível, do ponto de vista textual, ver como Aristóteles excluiria a possibilidade (ou até mesmo a necessidade) da semelhança qualitativa dos dados sensoriais brutos nos casos de indivíduos capazes de comparar as duas magnitudes e daqueles cujas experiências, ao contrário, ainda não conduziram à retenção da imagem referente ao tamanho de um pé, visto que eles possuem o mesmo tipo de aparato sensório.

\section{EM DEFESA DA PLURALIDADE SEMÂNTICA}

\subsection{Phantasía e phaínomai}

Não sendo factível, portanto, nem a identificação de um elemento unificador comum nos diversos fenômenos ligados à palavra "phantasía" em Aristóteles, nem a redução das sensações errôneas dos sensíveis comuns em termos de imagem, como haveria de se sustentar a univocidade do termo?

Além da ausência de esclarecimentos em passagens como a da magnitude do sol no De Anima III, nas quais a phantasía aparece ligada a uma atividade diversa da produção de imagens, parece não haver indícios nem argumentos capazes de estabelecer 
com consistência a tese segundo a qual o termo possui um sentido único ao longo da obra psicológica do Estagirita. De fato, ao ocupar-se do conceito de phantasía, Aristóteles transita com volubilidade entre as instâncias de fenômenos heterogêneos, sem dar mostras de consciência quanto ao arrojo de, por meio de omissões, insinuar que atividades tão distintas pertencem à alçada de uma mesma função anímica.

A estrutura do argumento do De Anima III, 428a18-b10, com o qual Aristóteles pretende rejeitar o conceito platônico de phantasía definido a partir da opinião e da sensação ${ }^{22}$ - seja enquanto opinião em conjunto com uma sensação, seja enquanto uma mistura de ambas ou uma opinião sensorialmente adquirida (DA III, 428a, 25-56) -, parece deixar entrever seu compromisso com a ligação entre o "phaínetai" de 428b3, referente ao aparecimento do sol como dotado da magnitude de um pé, e seu conceito de phantasía. A conclusão do raciocínio indica a relevância dessa conexão para uma resposta ao problema acerca do termo ainda a ser definido: fazendo uso das consequências decorrentes da noção platônica de phantasía e do comportamento do fenômeno ao qual o verbo phaínesthai corresponde, o filósofo conclui a inadequação daquela, dando a entender, assim, seu comprometimento com a ligação entre phantasía e sensibilidade - somente pressupondo tal compromisso por parte de Aristóteles pode o esforço argumentativo levado a cabo adquirir sentido:

\begin{abstract}
Aparecem também como falsas as coisas sobre as quais se tem ao mesmo tempo uma suposição verdadeira, como o sol aparece como tendo o tamanho de um pé, mas acredita-se ser ele maior que a Terra. Segue-se, então, ou a rejeição da própria opinião verdadeira, a qual se possuía, preservando-se a coisa, não havendo nem esquecimento nem persuasão, ou, ainda tendo-se a opinião, faz-se necessário ser esta verdadeira e falsa. Mas uma opinião verdadeira torna-se falsa quando se altera o fato despercebidamente. A phantasía, então, não é nenhuma dessas coisas, nem é composta delas. (DA III, 428b, 1-10) ${ }^{23}$.
\end{abstract}

Não se há de duvidar, assim, do vínculo entre phaínetai e phantasía, uma vez que as decorrências do funcionamento do fenômeno àquele correspondente fornecem

\footnotetext{
${ }^{22}$ Aristóteles é o primeiro na história da filosofia a distinguir claramente entre imaginação, concepção e sensação (HUBERT, 2005, 7).

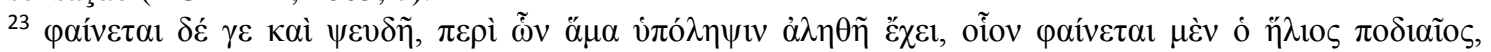

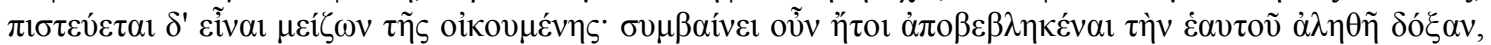

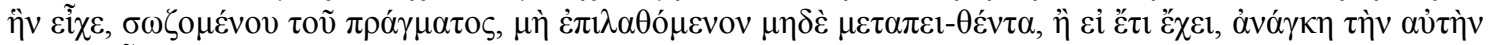

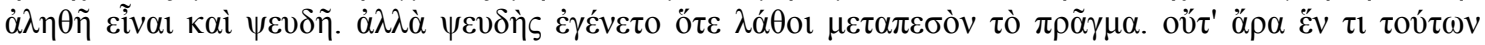

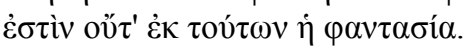


bases para se determinar o que esta não é ${ }^{24}$. Consequentemente, estando ligada ao verbo a atividade da faculdade sensitiva - "Visto que não dizemos, quando, acerca do objeto sensível, nosso sentido funciona claramente, que tal coisa nos parece um homem, mas quando não percebemos claramente" (DA III, 428a, 12-15) ${ }^{25}$-, estabelece-se o vínculo entre a phantasía e um dos tipos não paradigmáticos de atividade sensitiva.

\subsection{O De Insomniis e as aparências enganadoras}

O De Insomniis ${ }^{26}$, tratado no qual Aristóteles investiga o fenômeno dos sonhos, também traz o caso do aparecimento do sol enquanto dotado do tamanho de um pé, fortalecendo a ideia de uma phantasía ligada a aparições visuais. Na pequena obra cuja descrição dos mecanismos psicofísicos da phantasía supera em detalhe até mesmo o estudo feito no De Anima (MOSS, 2012, 51) - é permitido ter não apenas um vislumbre de tal vínculo, mas confirmar a suspeita, levantada já na leitura do De Anima III, a respeito da aceitação, por parte do filósofo, de uma influência direta da atividade da phantasía na criação de aparências visuais - influência essa distinta da mera conexão causal entre os produtos da imaginação e a faculdade sensitiva ${ }^{27}$, cujo ato constitui a origem "material” dos phantásmata ${ }^{28}$. Investigando os casos de aparições visuais falsas - dentre as quais se incluem não apenas as condicionadas pela distância, mas também as causadas por estados emocionais alterados ${ }^{29}-$, conclui Aristóteles:

\footnotetext{
${ }^{24}$ Barney chama a atenção para o apelo ao funcionamento de phaínetai como uma maneira de caracterizar a phantasía: "Ele [i.e., Aristóteles] toma nosso uso da linguagem da aparência como fornecendo indício do caráter da phantasía." (BARNEY, 1992, 290).

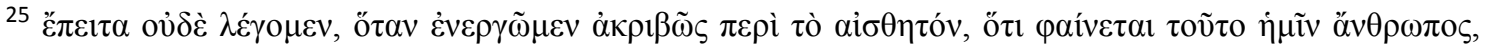

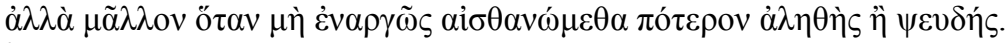

${ }^{26}$ Com exceção do estudo contido no De Anima III.3, o De Insomniis traz a mais longa análise do conceito de phantasía: "As discussões mais extensas de Aristóteles sobre a phantasía se encontram no DA III.3 e no De Insomn. A primeira discussão visa distinguir a phantasía da percepção e do pensamento, enquanto que a segunda tem por objetivo mostrar como a phantasía explica sonhos e outras ilusões perceptuais, mas há bastante consistência entre as duas." (MOSS, 2012, 51). Sobre o De Insomniis e a ideia de phántasma, vide Huby (1975).

${ }^{27}$ Como nota Labarrière $(2013,17)$, o tratamento da imaginação como algo puramente sensorial foi adotado também pelos filósofos medievais.

${ }^{28}$ No final do De Anima III.3, afirma Aristóteles: "Mas visto que é possível, algo tendo sido movido, outra coisa ser movido por ele, e que a phantasía parece ser um movimento e não ocorrer sem a sensação, mas para os que sentem e das coisas das quais há sensação, e visto que é possível ocorrer movimento pelo ato da sensação, e que tal movimento deve ser semelhante à sensação, tal movimento não seria capaz de ocorrer sem sensação, nem subsistir naqueles que não possuem, mas seu possuidor pode, de acordo com ele, muitas coisas fazer e sofrer, podendo ele ser verdadeiro ou falso." (DA III, 428b, 10-17). - $\dot{\alpha} \lambda \lambda^{\prime}$

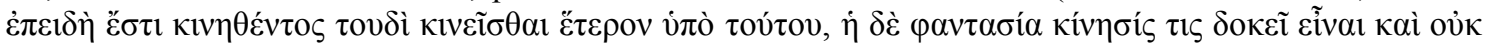

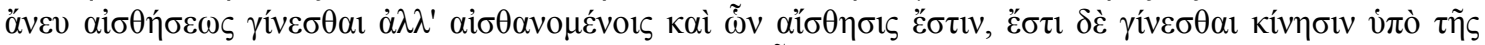

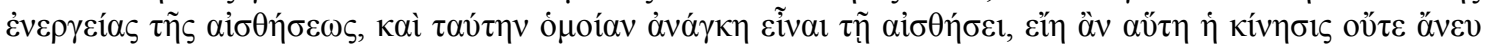

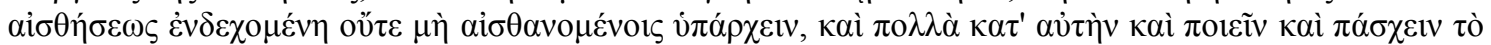

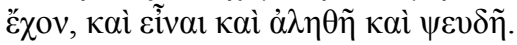

29 "Facilmente, estando sob o efeito das afecções, nos enganamos a respeito das sensações, uns em certas paixões, outros em outras, como o covarde sob o efeito do medo e o amante sob o efeito do amor, de
} 
A causa dessas ocorrências é que o discriminante principal ${ }^{30}$ (tò kýrion) não julga de acordo com a mesma faculdade pela qual ocorrem as imagens. Indício disso é que o sol parece medir um pé, mas constantemente outra coisa contradiz a phantasía. (De Insom., $460 \mathrm{~b}, 16-19)^{31}$.

Nessa passagem, torna-se patente a ligação entre a phantasía enquanto faculdade produtora de imagens e o caso da aparição do sol como dotado da magnitude de um pé. Ainda que tal ligação não estivesse, no De Anima III, de todo obscurecida - dada, por exemplo, a introdução do caso justamente nas linhas dedicadas ao estudo da phantasía , o termo não é ali empregado de modo direto para se referir ao fenômeno da aparição do sol, ou seja, não se emprega, no De Anima III, o termo "phantasía" para se referir à causa da produção dessa aparência, nem "phántasma" para designá-la. A conexão entre a phantasía e o fenômeno do tamanho ilusório do sol é estabelecida, nesse tratado, por meio do verbo "phaínomai", além da já mencionada inserção no contexto específico do estudo da faculdade. Já a passagem supracitada não permite que dúvidas persistam acerca da realidade da conexão.

O De Insomniis, fortalecendo a ideia de uma phantasía ligada à atividade sensorial, não se limita ao exemplo do sol e das distorções causadas por desequilíbrios passionais, mas também traz, logo após mencionar o fenômeno do tamanho aparente daquele, outros casos de aparências sensoriais enganadoras, como o dos dedos entrelaçados sobre um objeto qualquer: "Também por meio do entrelaçamento dos dedos algo parece ser duas coisas; não obstante, não dizemos haver duas coisas, pois a vista tem mais autoridade que o tato." (De Insomniis, 460b, 20-22) ${ }^{32}$.

\footnotetext{
modo que, com base em uma pequena semelhança, o primeiro julga ver os inimigos, e o outro, o amado."

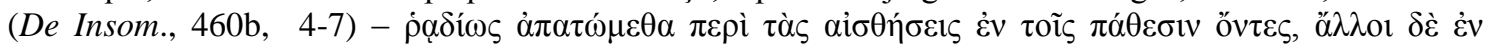

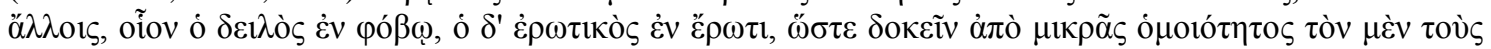

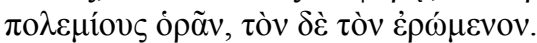

${ }^{30} \mathrm{Na}$ tradução de Hett (2000), "tò kýrion" aparece como "sentido controlador". De fato, o termo diz respeito a algo cujo julgamento sobrepuja o informado pela faculdade por meio da qual os phantásmata ocorrem. Todavia, uma vez que o exemplo imediato é o do caso da aparência enganosa do sol, infere-se a não necessidade de tò kýrion ser um sentido. Por meio de qual sentido, afinal, chega-se à conclusão a respeito do real tamanho do sol? Barney $(1992,289)$ prefere traduzir o termo por "aquilo que governa a alma", compreendendo não se tratar ali de uma modalidade sensória.

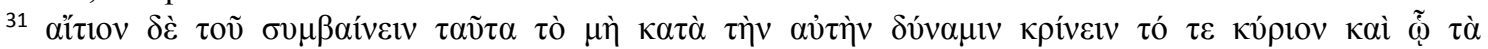

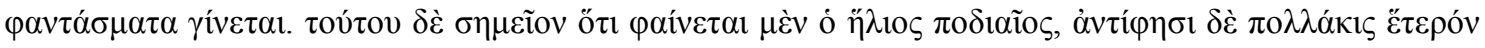

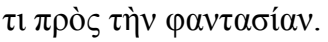

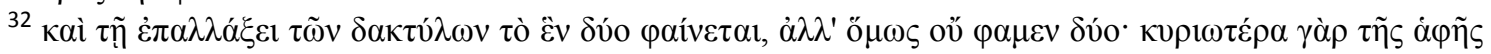

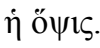


Infere-se legitimamente, portanto, a relação entre a phantasía sensorial, atrelada aos contextos de aparência enganosa, e a modalidade sensória imbuída de menor autoridade: há, tanto no exemplo do sol como no da última passagem citada, um conflito proveniente de atividades distintas, uma das quais, sobressaindo-se à outra, termina por ter seu veredito a propósito do fato aceito. A outra, incapaz de persuadir o indivíduo a aceitar como adequada a informação transmitida, torna-se a origem da aparência enganadora, a qual persiste, não obstante a retidão da crença.

\subsection{O elemento unificador}

Apesar de estar evidente, a partir do que foi visto, o comprometimento de Aristóteles com a relação entre o conceito de phantasía e as aparências sensoriais enganadoras, permanece envolto em mistério o ponto nevrálgico do caráter homogêneo dos à primeira vista tão diversos fenômenos ligados àquele. Mesmo sendo desenvolvida em mais detalhe, no De Insomniis, a descrição do mecanismo de funcionamento da aparência falsa, a partir da ideia de conflito entre duas atividades - ideia essa já presente de certo modo no De Anima III, quando o filósofo menciona a convicção acerca da real magnitude do sol (DA III, 428b, 4) -, nada parece ser esclarecido a respeito da suposta raiz comum entre sensação errônea em presença e criação de imagens em ausência. Aparentemente, porém, resta uma via para quem insiste em unificar a pluralidade dos fenômenos relacionados à noção de phantasía ao redor de um mesmo eixo.

Diferentemente do esforço empreendido pelos comentadores hodiernos - como Schofield e Sheiter -, os quais visam salvaguardar a consistência da abordagem do Estagirita lançando mão de recursos que apelam para supostos comprometimentos tácitos presentes no texto aristotélico, a melhor alternativa talvez esteja em um olhar cuidadoso sobre algumas linhas do De Insomniis, onde parece estar exposta uma tentativa de explicar a causa das aparências sensoriais enganadores. Assim afirma o filósofo, logo após mencionar o caso do conflito entre os dados obtidos por meio da visão e os coletados através da modalidade sensória do tato - i.e., no mesmo contexto da menção ao problema da aparência do tamanho do sol, a qual surge no corpo do texto entre os exemplos dos desequilíbrios emocionais e do conflito entre tato e visão: 
A causa do enganar-se é que certas coisas quaisquer aparecem não apenas quando o objeto sensível move, mas também quando a sensação move-se a si mesma, caso seja movida da mesma maneira que por um objeto sensível - digo, por exemplo, como no caso da terra firme que parece mover-se àqueles que navegam, tendo a vista sido movida por outra coisa. (De Insomniis, 406b, 23-27) ${ }^{33}$.

Nessa passagem, como se pode ver, é enunciado o evento responsável pela aparência falsa, a bem dizer, o movimento da sensação a partir dela mesma. Para que deste resulte o engano do sentido, é necessário haver a semelhança com o modo no qual ocorre o movimento produzido por um objeto sensível genuíno, isto é, por aquele objeto cuja existência não é meramente intrapsíquica, resultante de uma afecção da sensibilidade - como é o caso dos phantásmata -, mas externa, independente da inerência na alma de um ente sensitivo qualquer.

Dois problemas emergem das linhas há pouco citadas. O primeiro deles refere-se à origem - supostamente interna, i.e., localizada junto à própria sensação - do movimento envolvido na criação de uma aparência falsa. A partir do afirmado por Aristóteles na passagem supracitada, depreende-se não apenas a igualdade com relação ao modo como ocorrem tal movimento e aquele resultante da ação direta de um objeto sensível, mas também se infere a diferença em origem de ambos os movimentos: enquanto neste o responsável pela afecção possui uma realidade independente das funções anímicas, naquele a causa conecta-se diretamente à atividade psíquica, uma vez que é a sensibilidade o agente envolvido na circunstância de sua própria afecção. Todavia, como Aristóteles lança mão da interioridade do movimento para explicar situações de aparência enganosa?

Aos casos dos enganos resultantes de desequilíbrios emocionais poder-se-ia adequadamente aplicar o modelo explicativo proposto na última passagem destacada, pois, mesmo sendo externos os objetos sensíveis disparadores da aparência ludibriante, boa parte da responsabilidade jaz com as próprias imagens armazenadas do indivíduo, as quais vêm associadas ao ente a que se referem suas afecções de amor ou medo. Um indício para o papel ativo das imagens nessas situações é a potencial não correspondência entre a identidade do ente efetivamente visto e a legítima referência daquelas.

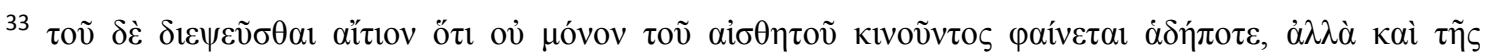

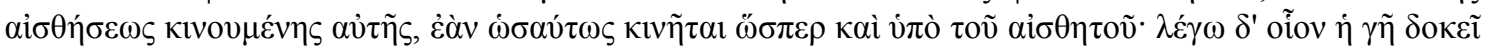

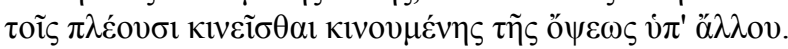


Quanto aos outros exemplos, todavia, permanece obscuro o modo pelo qual há de se encontrar em alguma imagem armazenada a causa do engano visual. No caso das aparências enganosas provenientes de perturbações afetivas, pode-se muito bem exemplificar o papel direto dos conjuntos particulares de imagens retidas a partir de um cenário hipotético onde o mesmo objeto é visto de maneiras diversas, justamente porque a associação de cada indivíduo depende de imagens armazenadas específicas ${ }^{34}$. Nessas situações, portanto, a interioridade do movimento - i.e., a afecção da sensibilidade por ela mesma - representa uma ótima tentativa de explicação para o fenômeno das aparências visuais enganosas. Percebe-se aqui a convergência entre a doutrina de Aristóteles e a redução de Scheiter para as sensações acidentais a termos de imagem, uma vez interpretado o movimento da sensibilidade por ela mesma como um caso em que se atribui o poder de afecção às imagens retidas, visto que o filósofo não utiliza o mesmo vocabulário em sua manobra reducionista. Ora, acima foi demonstrada a inadequação da abordagem de Scheiter para casos como o da magnitude do sol, justamente pela ausência de uma ligação clara entre esse tipo de aparência e algum conjunto de imagens retidas; supondo-se, portanto, que tal abordagem espelha a visão de Aristóteles, haveria, consequentemente, um problema interno ao seu pensamento no tocante à causa das aparências enganosas.

Outro problema surgido a partir da passagem citada é a referência da explicação proposta pelo filósofo: com o movimento da sensação por ela mesma, Aristóteles procura explicar qualquer aparência enganosa, ou apenas casos semelhantes ao dos dedos entrelaçados, nos quais há conflito entre duas modalidades sensórias? Por si só, o fluxo do texto não permite, à primeira vista, determinar uma resposta; além disso, com ambas as alternativas é possível, sem maiores entraves, construir um sentido para a passagem.

Nesse segundo problema, assim como no anterior, incidem as diferenças supostamente estruturais entre os fenômenos citados. Sob um primeiro olhar, Aristóteles parece trabalhar, ao abordar a questão das aparências falsas no De Insomniis, com quatro casos distintos: 1) desequilíbrios passionais, em que imagens e afecções contribuem para a maneira como o efetivamente visto aparece; 2) conflito entre sensação e intelecto, no qual o juízo deste, possuidor de maior autoridade, sobrepõe-se

\footnotetext{
${ }^{34} \mathrm{Na}$ verdade, os conjuntos de imagens retidas não constituem a totalidade de causas envolvidas na associação. Devem ser consideradas também, como mostra o próprio texto de Aristóteles (cf. nota 20), as afecções do indivíduo.
} 
ao daquela - o caso do sol sendo o exemplo paradigmático desse tipo de discordância; 3) conflito entre duas modalidades sensórias, como no caso dos dedos entrelaçados; 4) conflito dentro de uma mesma modalidade sensória.

Como exemplo desse último fenômeno ter-se-ia a situação mencionada no $D e$ Insomniis, 460b27, na qual a terra firme parece mover-se a quem está a navegar; fala-se aqui de conflito dentro de uma mesma modalidade sensória porque, como explicitado no texto, Aristóteles identifica a causa da aparência no movimento da vista provocado por outra coisa. Assim, a aparência enganadora, ela própria manifestada na vista, não se dá em função dos dados provenientes de um sentido de menor autoridade, como nas instâncias de conflito entre modalidades diversas.

$\mathrm{Na}$ passagem supracitada, evidencia-se a intenção do filósofo em tratar sob a mesma ótica o terceiro e o quarto caso; dessa forma, segundo Aristóteles, não haveria diferenças estruturais entre aparências envolvendo as atividades de dois sentidos distintos e aquelas que, apesar de visuais, não se enquadram no mesmo esquema da divergência entre modalidades sensórias de autoridades variadas. $O$ movimento da sensação por algo diverso de um objeto sensível constitui, portanto, a causa de ambos os tipos de aparências, sendo tal causa diferenciada o que permite afirmar o isomorfismo desses fenômenos.

O texto, porém, a despeito de ser explícito acerca da espécie de movimento envolvida no caso dos dedos entrelaçados - havendo os dados provenientes de dois sentidos, a sensação é movida por ela mesma -, não é igualmente claro no que diz respeito à causa do movimento da vista na situação descrita em De Insomniis, 460b27. Ao fazer uso da expressão "por outra coisa" (hyp 'állou), no intuito de indicar a origem do movimento ligado à falsa aparência de uma terra não estacionária, Aristóteles, ao contrário de determinar, parece deixar em aberto a questão da identidade dessa "outra coisa" capaz de mover a vista.

Havendo, portanto, tamanha distância entre afirmar a sensação como causa de seu próprio movimento e "outra coisa" como responsável por movê-la, parece precipitado, com base apenas nas expressões utilizadas, anunciar a ausência de diferenças entre os fenômenos psíquicos ocorridos nos casos dos dedos entrelaçados e da terra móvel. Afinal, do que se trata essa "outra coisa"? Qual é a natureza da causa da afecção envolvida na aparência enganosa de uma costa não estática?

De imediato, apenas uma resposta sobre o que tal coisa não é se impõe: seguramente, pode-se afirmar não se tratar, na passagem, de uma afecção causada pelo 
objeto sensível próprio da modalidade sensória da visão, uma vez que dentre as possibilidades dessa afecção não se encontra a aparência enganosa como resultado ( $D A$ II, 418a, 12). Sendo assim, exclui-se de antemão alguma cor enquanto possível referência da expressão sob exame. Também não constitui referência possível um objeto próprio de outro sentido, pois a aparência à qual conduz a circunstância da navegação ao longo de uma costa é de caráter puramente visual.

Contudo, apesar de críptica, a passagem pode, dentro de seu contexto, ser interpretada como indicando o mesmo tipo de movimento envolvido no caso anterior dos dedos entrelaçados; além disso - e aqui jaz a relevância da análise dessas breves linhas contidas em um tratado de menor porte -, ela contém a chave para a consistência interna do pensamento de Aristóteles a respeito da phantasía.

A despeito das diferenças entre as situações mencionadas - a da navegação e a dos dedos entrelaçados -, depreende-se da passagem que os movimentos relativos às aparências enganadoras possuem três características em comum. Em primeiro lugar, ambos são movimentos anímicos sensíveis, isto é, ocorridos no próprio cerne da sensibilidade. Em segundo lugar, tais movimentos assemelham-se fenomenologicamente àqueles causadas por objetos sensíveis próprios. Por último, não são eles causados por esses objetos. Quanto às duas primeiras características, não parece, à primeira vista, haver fundamentos para uma crítica à consistência da teoria aristotélica, pois ambas decorrem da ideia de uma phantasía enquanto uma submodalidade da função sensitiva. A respeito da terceira, porém, algumas considerações fazem-se necessárias.

De início, é mister ressaltar que a terceira característica não pode ser afirmada do movimento vinculado ao conflito entre visão e tato - no caso dos dedos entrelaçados - sem qualificação, pois dentre os envolvidos na criação da aparência encontra-se um objeto sensível próprio dessa última modalidade sensória. Uma leitura desatenta poderia apontar, nesse caso, uma suposta inconsistência com o afirmado por Aristóteles acerca da ausência de erro na atividade sensorial incitada pelos sensíveis próprios; contudo, o erro proveniente da informação advinda do tato não é relativo ao objeto o qual lhe é exclusivo, mas a um sensível comum, a bem dizer, ao número; o conteúdo da aparência falsa, como é evidente na passagem, refere-se a uma quantidade específica, a qual, apesar de não ter, através do toque, sua identidade revelada ao indivíduo, torna-se conhecida por meio da visão, o sentido dotado de maior autoridade. 
Na situação dos dedos entrelaçados, portanto, acerto e erro dizem respeito a um sensível comum. Investigando sob o mesmo viés a situação da terra não estática, nota-se que o engano ocorre relativamente a seu repouso; o repouso, assim como o número - e como sua negação, isto é, o movimento -, sendo passível de ser apreendido por mais de uma modalidade sensória, constitui, ipso facto, um objeto sensível comum (418a, 17), podendo, assim, ser referido erroneamente através de uma apreensão inadequada.

Desse modo, encontra-se outro aspecto comum a ambas as aparências. Analisando-se os demais casos - o da atribuição incorreta de identidades em situações de desequilíbrio emocional e o da magnitude do sol -, nota-se que o conteúdo das ilusões também se refere a sensíveis não próprios. Ora, havendo esse traço comum a todos os casos de aparência enganosa mencionados por Aristóteles nessa parte do De Insomniis, não se revela sem justificativa a hipótese segundo a qual o filósofo está a tratar, ali, de fenômenos homogêneos, ou seja, de uma única espécie de evento psíquico. As semelhanças, assim, suplantam as diferenças.

O que de particular há em cada circunstância - o tipo do objeto ao qual se atrelam os sensíveis não próprios (pessoas, astros, partes do corpo, terrenos, etc.), bem como o número de modalidades sensórias e de funções anímicas envolvidas - não se mostra suficiente para atribuir a Aristóteles a intenção de elaborar uma abordagem fragmentadora, a partir da qual cada aparência ilusória estrutura-se e origina-se de um modo diverso, sem a presença de qualquer traço característico partilhado por todas, traço esse capaz de legitimar a homogeneidade dos tantos enganos sensoriais.

A comparação feita pelo filósofo entre as duas aparências enganosas mencionadas na passagem supracitada, a abordagem dos quatro fenômenos em sequência e em um mesmo local, o tema do engano - o qual perpassa todos os casos mencionadas - e a presença de um sensível não próprio como um dos componentes na estruturação de cada uma das ilusões garantem o intuito do filósofo de fornecer uma explicação válida para todas, ou seja, ao apontar como causa do enganar-se acerca de uma quantidade específica e do repouso o movimento na sensibilidade provocado por algo que não um objeto sensível próprio, o texto, em conjunto com os pressupostos necessários para infundir sentido e consistência nas linhas estudas, permite expandir a análise a fim de englobar a totalidade dos fenômenos de engano sensorial. Desse modo, ao atribuir-se, por conta de um desequilíbrio passional, uma identidade não correspondente ao objeto de fato visto e ao perceber o Sol como dotado da magnitude de um pé, tem-se a sensação a mover-se a si mesma ou um movimento provocado por 
"outra coisa", a qual não pertence ao conjunto das qualidades cuja assimilação define o funcionamento específico de cada sentido.

As aparências ilusórias, portanto, são consequências de um movimento intrapsíquico peculiar, não proveniente da relação assimilativa entre uma modalidade sensória e seu objeto próprio. Tal movimento, fenomenologicamente semelhante à afecção causada por um objeto sensível genuíno, ocorre também na atividade produtora de imagens, fato esse que o torna a ponte conectora entre os fenômenos do ato imaginativo e da aparência sensorial enganosa. Além disso, ao centrar nesse movimento o mecanismo pelo qual surgem as ilusões, Aristóteles erige ao nível da consistência e da inteligibilidade suas considerações acerca do funcionamento do verbo phaínomai no De Anima III, 3.

Outra via ainda é possível para se estabelecer a homogeneidade dos fenômenos mencionados no De Insomniis. Pautando-se na comparação entre a manifestação do sol como dotado de uma magnitude não correspondente à realidade e a sensação errônea de uma terra não estática, nota-se que, na verdade, o fenômeno dessa última envolve um conflito idêntico em forma ao presente no caso do sol, e não, como antes havia sido suposto, uma discordância dentro de uma única modalidade sensória.

A aparência de um sol exageradamente pequeno e a de uma costa estacionária não se referem, obviamente, a um mesmo objeto sensível - na situação do sol, o engano ocorre relativamente a uma magnitude, enquanto na da navegação, a um repouso efetivo. Repouso e magnitude, apesar de não serem a mesma coisa, são ambos objetos sensíveis comuns a mais de um sentido; contudo, tal fato, ainda que central no estabelecimento de uma justificativa para tratar as duas aparências como estruturalmente homogêneas, não é o único capaz de embasar uma abordagem associativa. Aristóteles, considerando a aparência do sol dotado do tamanho de um pé, aponta para o conflito existente entre o dado obtido através da modalidade sensorial da visão e o juízo correto emitido pela parte racional da alma, o qual prevalece e persuade o indivíduo, afastando-se, assim, por conta da maior autoridade desta, a crença naquilo que se faz presente de maneira imediata à sensação. Se o contexto no qual emerge a aparência da terra não estática for com detalhe analisado, observar-se-á a existência de um conflito gerado a partir desse mesmo par de faculdades anímicas: enquanto a visão discrimina erroneamente o estado de coisas, apresentando um movimento ilusório, a razão enuncia a verdade acerca do repouso da terra. 
De onde mais proviria a correta enunciação relativa ao estado da costa estacionária? Certamente não da visão, pois esta, ao apresentar um movimento não factual, é a modalidade que está a incorrer em erro. Os demais sentidos revelam-se igualmente incapazes de corrigir a aparência enganosa e, dessa forma, persuadir o indivíduo a respeito do funcionamento efetivo da realidade. O mesmo se dá no caso do sol, em que as outras modalidades sensórias não são capazes de enunciar o verdadeiro por conta, obviamente, da distância entre o indivíduo e a coisa observada -, razão pela qual o termo "tò kýrion" em De Insom.460b não se traduz adequadamente por "sentido principal" ou "sentido controlador".

Assim como no exemplo do sol, portanto, a correta enunciação a respeito do estado de coisas provém, no caso da terra móvel, por uma via não sensorial - ou ao menos não de modo direto, como o é a maneira pela qual ocorre uma afecção em presença. Ainda que a opinião adequada sobre o repouso da costa dependa de sensações ocorridas em outras circunstâncias - quando, por exemplo, o indivíduo pôde, em diversas ocasiões no passado, observar a efetiva estabilidade da terra -, no instante da navegação é o "bom senso" que está a contradizer o informado pela via sensorial, isto é, algo pertencente a uma função de maior complexidade, cujo juízo sobrepuja o imediatamente percebido.

Havendo, assim, tanto no caso do sol como no da terra não estática, o conflito entre as funções psíquicas da sensação e da razão, pode-se afirmar serem estruturalmente semelhantes as aparências engendradas a partir de ambas as circunstâncias. Justifica-se, portanto, a conexão entre o caso dos dedos entrelaçados e o do sol - uma vez ser aquele explicitamente comparado, por Aristóteles, com o da navegação, e não haver diferenças fundamentais entre o surgimento da aparência do sol enquanto dotado da magnitude de um pé e da costa não estacionária. Como consequência, o movimento da sensação por ela mesma (ou por "outra coisa") explicaria também a ilusão relativa ao tamanho do sol, de modo que a causa aludida na menção às aparências da quantidade errônea de dedos e do movimento não factual da terra unifica as diversas instâncias de engano sensorial.

Uma vez unificadas as instâncias de ilusão sensorial por meio de um movimento intrapsíquico singular, o qual, apesar de fenomenologicamente semelhante ao causado por um objeto sensível, consiste em um ato da sensibilidade sobre si mesma, torna-se inteligível a análise do verbo phaínomai no De Anima III.3 através dos exemplos do sol 
e do ente que, visto a distância, assemelha-se a um ser humano ${ }^{35}$. Não somente tal análise adquire uma clareza cuja ausência se faz notar em uma leitura superficial, mas também passam a ter sentido e relevância os argumentos dela provenientes a fím de caracterizar a phantasía: aquele movimento, do qual esta depende, é um componente tanto do fenômeno psíquico do engano sensorial como dos atos imaginativos propriamente ditos.

Assim sendo, não apenas a produção de imagens não é passível de ser explicada em termos de sensação básica, i.e., sem referência à operação sensível mais refinada da phantasía, mas também a aparência do sol como dotado da magnitude de um pé exige um tipo de sensibilidade capaz de afetar a si mesmo, aberto não somente à atividade dos objetos sensíveis.

Alguns adendos, todavia, são necessários: em primeiro lugar, afirmar que a sensação dos sensíveis comuns e acidentais requer a phantasía não equivale a atribuir a esta uma suposta capacidade de interpretar ou sintetizar dados sensoriais ${ }^{36}$ - o resultado aqui obtido através da leitura do De Insomniis não coaduna, portanto, com interpretações especulativas como a de Nussbaum; em segundo lugar, o envolvimento da phantasía nos casos de apreensão dos sensíveis comuns não pressupõe nem a atividade imaginativa nem o uso de imagens acumuladas, pois a aparência enganadora

\footnotetext{
${ }^{35}$ Como Barney nota $(1992,288)$, em concordância com o observado por Aristóteles em relação aos usos do verbo phaínomai, a "linguagem de aparência" é utilizada em contextos nos quais se reconhece a lacuna entre a certeza e a informação efetivamente disponível: "Dizer que o graveto me parece torto equivale a dizer que minha phantasía do graveto é que ele é torto; e isto equivale a dizer que eu silenciosamente afirmo o pensamento (que de alguma forma envolve a percepção) de que ele assim é. Mas o 'aparente' é caracteristicamente associado com percepção visual, e especialmente com suas fraquezas; por isto ele é contrastado com o que é ou poderia ser descoberto como sendo o caso em uma reflexão ou exame mais cuidadoso. Assim, a função peculiar da linguagem de aparência é marcar um juízo como dispensável por estar baseado em uma informação preliminar em uma informação perceptual particular. Nós usamos a linguagem de aparência para expressar o reconhecimento de que algum procedimento de investigação com autoridade poderia muito bem fornecer um resultado oposto ao juízo que emitimos." Barnes e Annas (1985, 23-4), ao tratarem dos usos do verbo "aparecer", mencionam uma distinção entre um sentido fenomenológico, ligado ao modo como as coisas afetam o indivíduo, e um sentido judicativo, no qual o verbo expressa suas crenças. Tomando-se tais sentidos como parâmetros, sem necessariamente limitar as instâncias de aparência como envolvendo apenas um deles, poder-se-ia determinar a qual dos extremos mais se aproxima cada fenômeno ligado à phantasía aristotélica. Longe de consistir em um mero exercício diletante, esse esforço poderia adicionar novas tonalidades ao debate acerca do pluralismo semântico do termo.

${ }^{36}$ Valendo-se das palavras de Lefébvre (2003, 33), a phantasía não é o "estrato hermenêutico" da sensação. Esta não deve ser vista, portanto, como algo passivo a ser interpretado por uma função superior. Contudo, a afirmação segundo a qual a faculdade sensitiva é capaz de levar a cabo suas operações mais complexas sem o auxílio da phantasía não há de ser entendida sem qualificação: como foi demonstrado, a phantasía é ativada nos casos de sensação dos comuns e dos acidentais, de modo a estar sua ocorrência atrelada à apreensão dos sensíveis não próprio; seu papel, porém, não é interpretativo, mas psicofisiológico. A sensação dos objetos não próprios, portanto, necessita da phantasía (não para interpretá-la, mas para proporcionar o movimento intrapsíquico característico das aparências enganadoras).
} 
relativa ao tamanho do sol ocorre em virtude de um movimento que, apesar de se tratar do mesmo tipo de afecção envolvido na imaginação, i.e., de um movimento na sensibilidade causado por ela mesma, não consiste em um produto do ato imaginativo (para preservar, a despeito da abordagem unificadora, a singularidade de cada fenômeno, basta relembrar a ainda mantida dicotomia ausência-presença) - desse modo, a conclusão aqui traçada não aponta para o mesmo caminho da abordagem reducionista de Scheiter.

Sem extrapolar as evidências textuais, portanto, é possível, com uma concepção "minimalista" de phantasía, a qual procede unicamente dos aspectos a esta atribuídos de maneira explícita nos textos de Aristóteles ${ }^{37}$, dissipar a suspeita de inconsistência a qual surge da ligação, através de um mesmo conceito, entre ato imaginativo e aparência visual enganadora. Não sendo possível ignorar o vínculo entre o verbo phaínomai e seu correlato substantivo, uma vez que o filósofo apela para o funcionamento daquele na linguagem quotidiana a fim de argumentar em prol da diferença entre sensação e phantasía, era necessário, sob pena de atribuir a Aristóteles uma posição inconsistente dada a lacuna aparentemente intransponível entre os diversos fenômenos mencionados no estudo desta -, explicar como ilusões sensoriais e atividade imaginativa são em última análise referidas a um mesmo conceito. Observa-se que, por meio da ideia de um movimento sensível autocausado, é possível identificar o cerne comum a todos os fenômenos remetidos à noção de phantasía, de modo a não resultarem sem sentido as considerações, em uma mesma parte do De Anima, a respeito da produção de imagens e do erro sensorial.

Contudo, a dicotomia ausência-presença, relativa ao objeto capaz de incitar o movimento na sensação, não é abolida com a identificação de um cerne comum às instâncias de aparência sensorial enganadora e aos atos imaginativos: estes permanecem caracterizados pela atividade a despeito da ausência do objeto sensível, enquanto aquelas, ao contrário, estão condicionadas à sua presença - para o Sol aparentar ser dotado da magnitude de um pé, faz-se necessário tê-lo ao alcance da visão, assim como

\footnotetext{
${ }^{37}$ Moss $(2012,52)$, isolando as três características explicitamente atribuídas por Aristóteles à phantasía origem sensorial (todos os casos de phantasía baseiam-se de alguma forma em um episódio de sensação), independência em relação à presença do objeto sensível e semelhança fenomenológica com os produtos da faculdade sensitiva (os efeitos psicológicos dos phantásmata são similares aos dos aísthẹmata, de modo que a phantasía de um objeto é muito parecida com a sua efetiva sensação -, afirma ser possível explicar todos os fenômenos vinculados a ela lançando-se mão apenas da concepção "minimalista", construída unicamente a partir desses aspectos. Não haveria a necessidade, portanto, a despeito do hermetismo do texto aristotélico, de introduzir papéis não explicitamente atribuídos à phantasía, tais como a interpretação e a síntese de dados sensoriais.
} 
é preciso o contato com os dedos entrelaçados para haver a sensação errônea a respeito de sua exata quantidade. Assim sendo, interpretam-se ambas as phantasíai levando-se em conta não apenas seu aspecto psicofisiológico comum, mas também uma diferença relacional: a dos atos imaginativos pode, do ponto de vista psicofísico, ser analisada como o movimento sensível autocausado cuja ocorrência se dá a despeito de o objeto não estar, no instante em que a imagem é produzida, diante de um dos cinco sentidos; já a phantasía das aparências sensoriais errôneas é decomposta como o movimento sensível autocausado cuja ocorrência depende da presença, diante de um dos sentidos, de um objeto comum a mais de uma modalidade sensória. Sobre essa última parte da análise das ilusões sensíveis, faz-se mister algumas palavras.

\subsection{Objeto sensível}

Na primeira linha da passagem crucial do De Insomniis, exatamente em 460b23, lê-se: "A causa do enganar-se é que certas coisas quaisquer aparecem não apenas quando o objeto sensível move"38. À primeira vista, parece haver aqui uma inconsistência: as aparências enganosas não se referem a objetos sensíveis? A ocorrência delas não requer, além disso, a presença das coisas às quais estes inerem? A esta altura, todavia, resta clara, a partir da passagem analisada do De Insomniis, a não atuação direta dos objetos sensíveis comuns e incidentais na ocorrência do movimento sensorial autocausado.

A fim de preservar a consistência do texto de Aristóteles, faz-se necessária uma interpretação específica do termo "objeto sensível” em 460b23. Apesar de as aparências sensoriais ilusórias se referirem a objetos sensíveis comuns ou incidentais, o movimento intrapsíquico que lhes é correspondente não é causado, stricto senso, por estes, como se pode averiguar na passagem - tal movimento tem sua causa, afinal, na própria sensação. Todavia, como pode um movimento sensível ser autocausado e ao mesmo tempo depender da presença de um objeto sensorialmente apreensível? Na passagem, evidencia-se um ponto decisivo: quantidades, magnitudes e indivíduos particulares dentre outros objetos que formam o conteúdo das aparências sensoriais enganadoras não são, ao menos no contexto do De Insomniis, objetos sensíveis. Consequentemente, eles não são capazes de incitar a sensibilidade da forma como o fazem sensíveis genuínos; a afecção causada por estes - infere-se do texto -, ao invés de resultar em

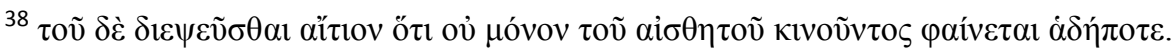


uma aparência errônea, dá ensejo a uma sensação correspondente a um estado de coisas efetivo. O termo “objeto sensível”, portanto, é utilizado, em 460b23, em seu sentido estrito, devendo ser interpretado como estando a se referir aos objetos sensíveis próprios, cuja apreensão é da alçada da especificidade de um único sentido.

No intuito de dissolver por completo a tensão surgida a partir da necessidade da presença diante dos sentidos de algo cuja aparência resulta de um movimento intrapsíquico autocausado, algumas considerações acerca do conceito de objeto sensível próprio revelam-se oportunas. Em primeiro lugar, uma característica do sensível próprio é a capacidade de ser, por si só (kath 'hautó), apreendido sensorialmente (418a, 7-11): quando em contato com um sensível próprio, o órgão sensorial - ou, em termos gerais, a sensação - é movido por conta desse contato, não de algum resíduo sensório ou de um ato da sensibilidade sobre si mesma. Na relação entre esta e um objeto próprio, portanto, observa-se o caráter externo da causa do movimento. Em segundo lugar, a afecção produzida por um sensível próprio não resulta em erro, i.e., em uma aparência enganadora, sendo sempre (ou quase sempre) verdadeira, de modo a se poder traçar a correspondência entre movimento sensível externamente causado e verdade - entre movimento intrapsíquico não autocausado e aparência sensível não enganadora.

Se uma das características essenciais do objeto sensível próprio é a capacidade de afetar a sensação por si só, os comuns e acidentais podem ser caracterizados pela ausência dessa capacidade (DA III, 425a, 14-19) $)^{39}$. Paralelamente, se da afecção direta ${ }^{40}$ ou externa decorre a adequação entre o sensorialmente apreendido e o real estado do objeto causador do movimento intrapsíquico, de uma afecção indireta ou interna - como a relacionada à aparência dos sensíveis comuns e acidentais - decorre a possibilidade do erro. A partir da distinção traçada no De Anima II entre os três tipos de objetos sensíveis e seu modo de relacionar-se com a faculdade anímica capaz de assimilá-los, não apenas o De Insomniis 460b-23-27 clarifica-se, mas também é dissolvido o problema ligado à necessidade da presença da coisa para a ocorrência de um movimento sensível autocausado.

Enquanto o sensível próprio atua como causa direta do movimento na sensação, os sensíveis comuns e acidentais atuam como causas indiretas, ou seja, de certa maneira

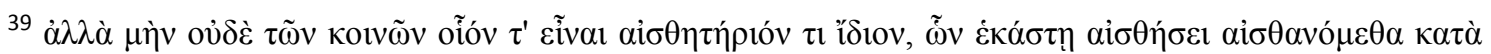

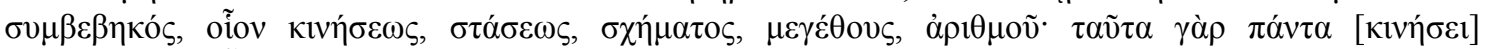

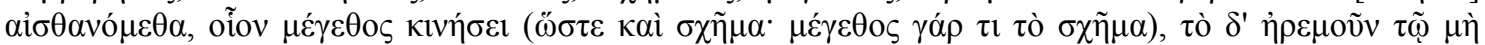

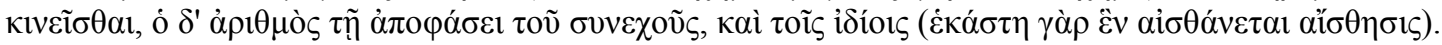

40 "Diretamente" é uma das traduções possíveis de "kath 'autó" no contexto da ação dos objetos sensíveis próprios sobre os órgãos sensoriais.
} 
eles constituem um elemento indispensável para afecção na medida em que sua presença diante dos sentidos é necessária - a aparência a eles referente é simultânea ao contato sensório -, mas o movimento intrapsíquico aludido no De Insomniis, fenomenologicamente semelhante àquele que resulta do contato com os sensíveis próprios, é em última instância causado não pelos comuns ou incidentais, mas pela própria sensação. A diferença etiológica entre os movimentos sensíveis diretamente causados por um objeto próprio e aqueles indiretamente causados - desencadeados por um sensível comum ou acidental, mas resultantes de um ato da própria sensibilidade pode ser retratada ao se decomporem seus respectivos processos.

Na sensação dos próprios, observa-se, por um lado, a causa da afecção, a qual é externa, e, por outro, o afetado - este equivale, no nível físico-material, ao órgão do sentido, e no âmbito psíquico-formal, à parte sensitiva da alma. De certo modo, a afecção diretamente causada pelo objeto é imediata: não há, na apreensão dos próprios, outro ato da sensibilidade que não o decorrente de seu caráter assimilativo, i.e., a sensação é, nesse caso, passiva. Contudo, na sensação dos comuns e incidentais, a qual muitas vezes resulta em aparências enganadoras, a sensibilidade é também ativa, visto que os objetos comuns e incidentais apenas desencadeiam o ato da sensação sem diretamente afetá-la; há, nesse caso, a identidade entre a causa da afecção e o afetado, o que indica o caráter mediado do movimento intrapsíquico relativo às ilusões sensórias: entre a capacidade do objeto de se manifestar e sua respectiva aparência ao indivíduo no âmbito psíquico há não a passividade assimilativa da sensação, mas o ato desta como causa do movimento. Nas instâncias de aparência enganadora, portanto, a sensibilidade é não apenas receptiva, mas também ativa; todavia, é justamente nessa atividade da sensação que reside a abertura ao erro, apesar de o modo como ocorre a afecção autocausada da sensibilidade assemelhar-se ao modo como um sensível genuíno a afeta.

A atividade imaginativa e a sensação errônea dos sensíveis próprios e acidentais, a despeito de esta, ao contrário da primeira, ocorrer na presença no objeto, indicam um movimento sensível cuja origem é interna. Essa interpretação, além de tornar inteligível o uso feito por Aristóteles do funcionamento do verbo phaínomai na tentativa de elucidar o caráter da phantasía - todos os fenômenos ligados àquele constituem instâncias dessa função psíquica -, elucida o motivo pelo qual, na teoria aristotélica da alma, apenas os sensíveis próprios são capazes de, por si sós, mover a sensação. A aporia relativa ao fato de Aristóteles tratar, no De Anima III.3, a ligação entre phaínomai e phantasía como não meramente etimológica repousa sobre um equívoco 
acerca da ideia de phantasía em presença. Como o De Insomniis deixa claro, o fato de uma aparência ser visual ou pertencer à alçada de qualquer outra modalidade sensória não a exclui como instância de phantasía. Em outras palavras: a ocorrência na presença do objeto não torna o fenômeno redutível exclusivamente aos termos da sensibilidade ligada aos órgãos sensoriais. A aporia da multiplicidade dos fenômenos aos quais a phantasía se refere dissolve-se, uma vez que a lacuna entre os mais diversos deles é preenchida com a ideia de um movimento intrapsíquico autocausado.

\subsection{A pluralidade semântica na filosofia de Aristóteles}

A descoberta de uma explicação psicofísica válida para todos os fenômenos ligados à phantasía, apesar do valor hermenêutico, dá ensejo à pergunta sobre a viabilidade de uma abordagem cuja proposta é investigar os múltiplos sentidos do termo: a menção, no texto de Aristóteles, ao movimento sensível autocausado, um conceito aplicável tanto às instâncias de aparência sensória quanto aos casos de produção de imagens, não frustra, afinal, a tentativa de investigar a pluralidade semântica da phantasía, uma vez que a psicofísica é a mesma para todos os fenômenos? Não estaria estabelecida definitivamente a univocidade do termo? De modo algum.

Uma explicação psicofísica comum a todas as instâncias não é suficiente para evitar a pluralidade de significados passíveis de serem assumidos por um termo, pois, mesmo ocorrendo em todos os fenômenos ligados à phantasía, o movimento sensível intrapsíquico não é capaz de anular diferenças semânticas mais sutis: no De Anima III, o termo "phantasía" parece designar não apenas uma capacidade, mas também um processo e o resultado dessa capacidade (FREDE, 1992, 280) ${ }^{41}$. Tais diferenças, perdurando a despeito de haver um fato psicofísico comum a fenômenos aparentemente heterogêneos, demandam uma abordagem que leve em consideração os múltiplos sentidos do termo.

O pluralismo de significados, longe de entrar em conflito com a existência de algo aplicável às várias instâncias relativas a um termo e constituir, assim, um indício contra a consistência da doutrina aristotélica, representa, no pensamento do filósofo, um lócus privilegiado. Ao notar a multiplicidade de usos de um termo, Aristóteles costuma investigar os diversos sentidos que este pode assumir, sem negar o fato de haver algo aplicável a cada um dos significados possíveis. O conceito de ser, por exemplo, o qual é

\footnotetext{
41 "O termo 'phantasma' era utilizado por Aristóteles intercambiavelmente com 'phantasia'".
} (STEWART, 2002, 291). 
dito multiplamente, tem no conceito de substância a referência comum a todas as categorias ontológicas (Meta. VII, 1003b, 5-10); do mesmo modo, o conceito de causa, possuindo múltiplos sentidos (id., V, 1013b, 5), encontra na resposta à pergunta "por quê?”, i.e., na explicação, o elemento partilhado por seus diferentes usos (FALCON, 2014, seção 2). A pluralidade semântica, portanto, é reconhecida e abarcada pelo pensamento de Aristóteles, coexistindo com entidades, conceitos e fenômenos capazes de estabelecer o vínculo entre os múltiplos sentidos.

Assim como as noções de substância e explicação não dissolvem a pluralidade semântica, respectivamente, dos termos "ser" e "causa", também a ideia psicofísica de um movimento sensorial autocausado não desmantela o conjunto das diferenças entre as possíveis acepções de "phantasía". A presente abordagem interpretativa, além de coadunar com o método de Aristóteles, fornece, ancorada nas evidências textuais, aquilo que a miscelânea de fenômenos referidos pelo termo parecia tornar impossível: a pedra de toque para a consistência de sua visão acerca da phantasía. 


\section{CAPÍTULO II: O SENTIDO NÃO PSICOLÓGICO DA PHANTASÍA}

\section{A PHANTASÍA DAS CORES}

\subsection{O caso do De Sensu}

Nos tratados do corpus acerca dos fenômenos anímicos, o sentido não psicológico da phantasía surge em uma passagem do De Sensu relativa à cor. Definindo esta como o limite (éskhaton) da transparência inerente aos $\operatorname{corpos}^{42}$, o filósofo estabelece a relação entre delimitação somática e phantasía: "Nos corpos, se o ambiente circundante não causa alteração, delimita-se também a phantasía da cor" (De Sensu, $439 \mathrm{~b}, 5-6)^{43}$. Esse fenômeno contrasta com a inconstância na manifestação da cor presente em algo indeterminado (aorístói) como o ar e a água, cujas colorações aparecem diversas dependendo da distância mantida entre eles e seu observador ${ }^{44}$.

\subsection{O realismo de Aristóteles}

A razão de se afirmar tal ocorrência do termo "phantasía" como indicador de um sentido não psicológico é o fato de a phantasía estar aqui sendo atribuída não a um conjunto de funções anímicas, mas a um objeto sensível. O De Anima deixa patente a posição realista de Aristóteles a respeito de objetos dessa espécie; as cores, por exemplo, não possuem uma existência subjetiva, dependente do ser que as percebe, mas encontram-se, ao contrário, nas próprias coisas, não obstante a possibilidade de estarem fora do campo de visão e passando, assim, despercebidas:

Visto que é uma a atividade do objeto sensível e a do ente sensitivo,
apesar de diferirem quanto ao ser, é necessário que a audição em ato
cesse ou preserve-se simultaneamente ao som, o mesmo se dando com
o sabor e a gustação e com todos os outros. Contudo, isso não é
necessário relativamente aos objetos sensíveis ditos no sentido
potencial; os primeiros fisiólogos não falaram corretamente ao
considerar que nada é branco ou preto sem a visão, ou que não há

42 "Claro está que seria algo o limite do transparente nos corpos, e que é evidente a partir dos fatos que tal

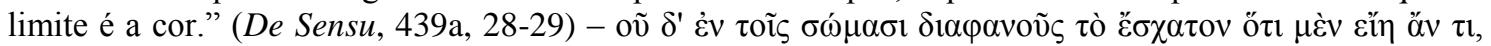

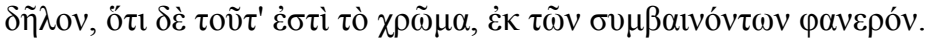

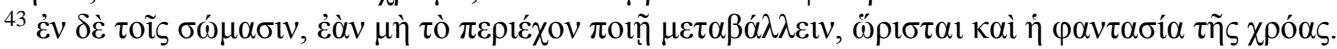

44 "Parece que também o ar e a água possuem cor, pois seu brilho é de tal tipo. Mas, nesse caso, por conta do estar em algo indeterminado, nem o ar nem o mar possuem a mesma cor a curta distância e aos que a

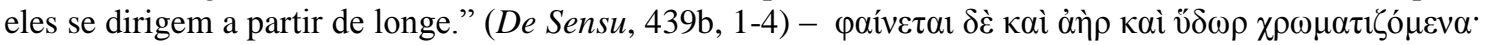

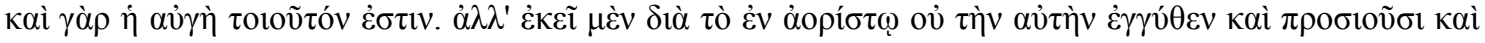

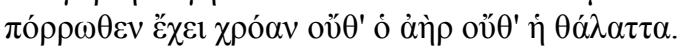


sabor sem a gustação. Em certo sentido, por um lado, falaram corretamente; em outro, porém, erraram: sendo ditos em dois sentidos a sensação e o objeto sensível - em potência e em ato -, quanto ao ato sua afirmação vinga, mas não quanto à potência. Eles trataram como dotados de um único sentido coisas ditas em mais de um sentido. (DA III, 426a, 18-28) $)^{45}$.

A cor, portanto, está no âmbito da coisa em si, possuindo existência objetiva. Ainda que não percebida, ela possui em si mesma a capacidade de aparecer com suas características próprias ao ente sensitivo, e tal capacidade independe do ser apreendida pela visão. Os objetos sensíveis, como afirmado na última passagem citada, possuem um ser (tò ê̂nai) próprio, diferente do ser dos entes sensíveis. Essa diferença em essência indica a autonomia ontológica daqueles em relação a esses últimos.

Mesmo na ausência do ente capaz de percebê-los, os objetos sensíveis exercem determinada atividade: Aristóteles nomeia "sonância" (psóphessis) a atualização da potência de produzir som $^{46}$ e insiste em diferenciar esse tipo de atividade daquela dos sentidos ${ }^{47}$. O mesmo se dá com o restante das modalidades sensórias e seus respectivos objetos, apesar da limitação vocabular:

O mesmo argumento se aplica aos outros sentidos e objetos sensíveis. [...] Mas, em alguns casos, há nomes, como "sonância" e "audição", enquanto que em outros não há nome para uma das atividades: à atividade da visão atribui-se o termo "vista", mas não há nome para a atividade da cor. (DA III, 426a, 9-14) $)^{48}$.

Assim sendo, a cor exerce uma atividade cuja realização independe do ser percebido. A abordagem realista do De Anima, quando trazida à tona juntamente com as condições mencionadas em De Sensu, 439b, 1-6 para a existência ou não de uma phantasía das cores determinada - tais condições (a delimitação ou ausência de

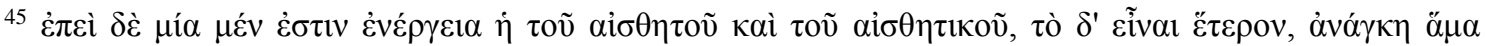

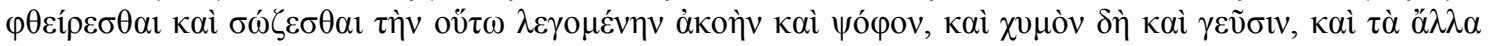

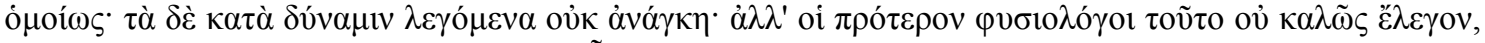

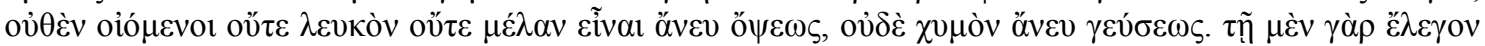

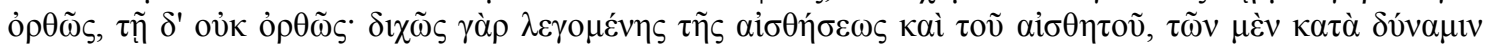

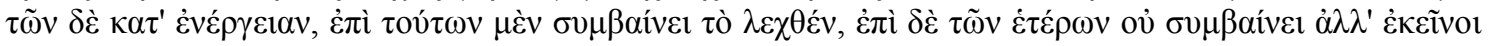

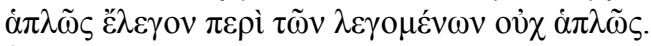

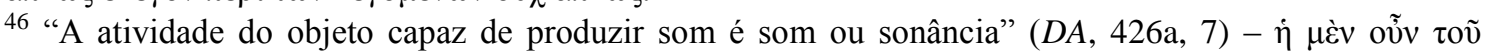

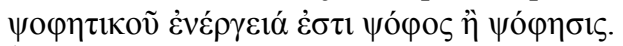

47 "A atividade do produtor de escuta é audição ou escuta, pois a audição é dita em dois sentidos, assim

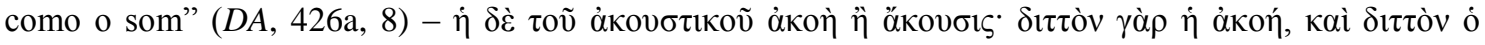

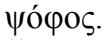

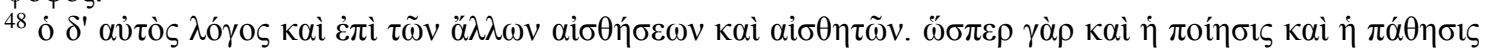

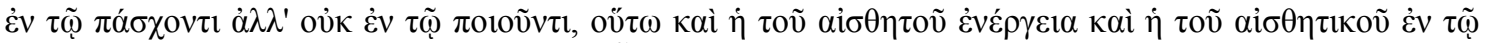

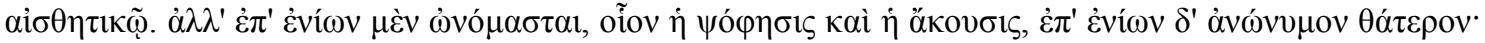

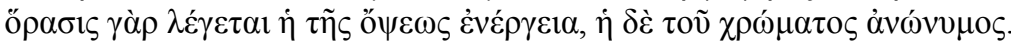


delimitação daquilo a que se atribui cor, bem como a constância ou alteração do ambiente circundante) são todas externas, i.e., são estados de coisas no mundo relativos àquilo no qual é inerente a cor - auxiliam a evidenciar o sentido não psicológico expresso na ocorrência do termo "phantasía" na passagem citada.

\subsection{Uma dimensão psicológica insuperável?}

O próprio De Sensu, ao iniciar a análise do objeto da visão, torna manifesta a dicotomia estabelecida por Aristóteles entre as dimensões do ente sensitivo e das qualidades por estes captadas através dos sentidos ${ }^{49}$, de modo que é possível estabelecer uma abordagem a respeito do objeto sensível com certo grau de autonomia relativamente ao âmbito psicológico da sensação, ou seja, é possível estudar o que a cor, por exemplo, é em si mesma, constituindo tal estudo uma investigação diversa daquela do objeto sensível enquanto relacionado aos sentidos que o captam. Aristóteles, contudo, não idealiza, com seu projeto de analisar o em-si dos objetos dos sentidos, uma abordagem completamente desvinculada da dimensão da sensibilidade - ao contrário, tal estudo joga luz sobre a atualização da sensação: "Digamos, agora, o que cada um deles [i.e., dos objetos sensíveis] há de ser a fím de produzir a sensação em ato" (De Sensu, 439a, 17 $)^{50}$.

Por uma série de motivos, poder-se-ia levantar a objeção de que o significado do termo "phantasía" em De Sensu 439 b6 não prescinde de conotações psicológicas. Em primeiro lugar, há a menção ao observador, para quem é variável, conforme a distância, o aspecto daquilo que possui cor, mas não é delimitado como o são corpos sólidos $^{51}$. Em seguida, há a questão da necessidade da referência à dimensão sensitiva: caso a ocorrência traga de fato o sentido de aparência ${ }^{52}$, dever-se-á inevitavelmente psicologizá-la, pois aparências são para o ente a quem algo aparece ${ }^{53}$. Por último, é

\footnotetext{
49 “Em linhas gerais, foi tratado, nos escritos sobre a alma, acerca dos objetos sensíveis correspondentes a cada um dos órgãos sensoriais [...], tendo sido explicado qual é sua função, bem como sua atividade segundo cada um dos órgãos sensoriais. Deve-se investigar, porém, como se deve descrever cada um deles, i.e., o que é a cor, o som, o odor e o sabor, assim como o toque. Primeiramente, tratemos da cor."

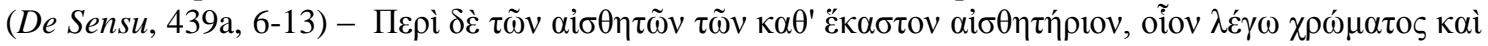

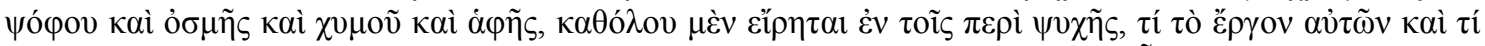

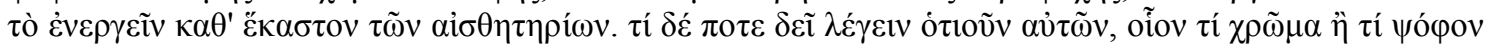

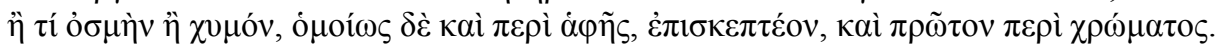

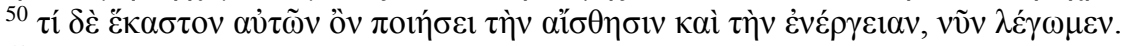

${ }^{51}$ De Sensu, 439b, 1-4.

${ }^{52}$ Como pode ser encontrado na tradução de Hett (2000).

${ }^{53}$ Essa decorrência não passa despercebida aos comentadores: "Outra ambivalência está relacionada com o duplo aspecto, tanto objetivo como subjetivo, que acompanha a phantasía, na medida em que pressupõe
} 
razoável questionar se a atribuição de phantasía a um objeto sensível realmente garante um significado não psicológico, afinal, parece possível desmembrar o enunciado de acordo com uma interpretação diversa, a qual salvaguarda um sentido psicológico: a phantasía é dita de um objeto sensível não porque ela está no mundo, mas porque, enquanto fenômeno anímico, ela se refere a tal objeto.

De fato, parece impraticável uma desvinculação completa do âmbito psicológico, uma vez que o filósofo estabelece a convergência das atualizações relativas à sensação e seu objeto através da potência desta ${ }^{54}$. Isso se deve ao fato de ambos os atos encontrarem-se no paciente: "Assim como a ação e a afecção estão no paciente, não no agente, assim também a atividade do objeto sensível e a do ente sensitivo estão neste" (DA III, 426a, 10-11) ${ }^{55}$.

Contudo, a diferença em essência desses atos permite, dado o duplo sentido em que os termos "sensação" e "objeto sensível" são utilizados, reconhecer quatro casos diversos - e não três, como haveria de ser na hipótese da identidade essencial das mencionadas atividades (o que estaria em conflito com a posição realista de Aristóteles) -, a bem dizer, o estado potencial do objeto sensível, seu respectivo ato, o estado potencial da sensação, e, por fim, o ato desta.

Há a convergência entre ambas as atividades, o que se dá principalmente como uma imposição da dinâmica da sensibilidade ${ }^{56}$, mas a diferença em momento algum deixa de ser mantida. Ao contrário, ela volta a ser afirmada no De Sensu, como recapitulação das linhas do De Anima:

Cada um desses termos é dito em dois sentidos: enquanto potência ou enquanto ato. Foi dito nos escritos sobre a alma de que modo cor e

algo que aparece, mas também algo ou alguém a quem se aparece de certo modo.” (MARCOS, 2009, 13).

54 "É necessário que o som e a audição em ato estejam na audição em potência" (DA III, 426a, 3-4). -

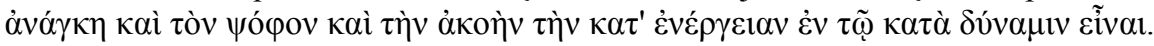

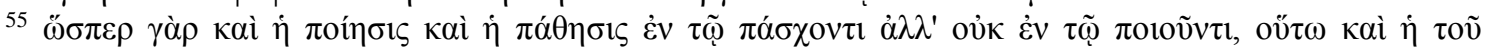

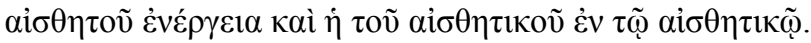

56 "Primeiramente, falemos do ser afetado e movido como se fosse o mesmo que exercer a atividade, pois o movimento é certa atividade, ainda que incompleta, como dito alhures. Tudo é afetado e se move pelo agente e pelo que é em ato. Por isso, é possível ser afeado pelo semelhante, assim como pelo diverso, segundo dissemos, pois é afetado o diverso, mas, terminada a afecção, já é semelhante." (DA II, 417a,

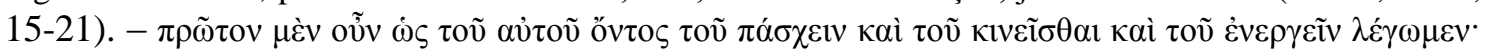

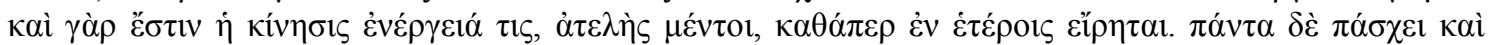

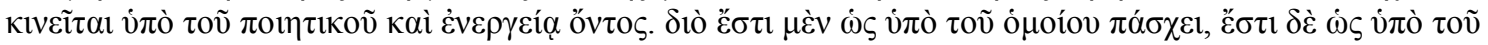

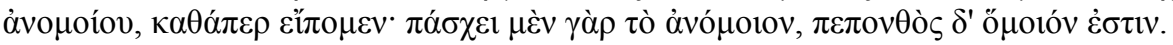


som em ato são iguais ou diferentes das sensações em ato, como a vista e a escuta. (De Sensu, 439a, 13-16) ${ }^{57}$.

Ao preservar a diferença na semelhança, Aristóteles abre caminho para, através daquela, considerar o em-si de algo que, apesar de estar estruturalmente vinculado à dimensão anímica, insere-se em um âmbito no qual certa atividade é realizada no próprio mundo externo, em contraposição a processos dados intrapsiquicamente. Dessa forma, a vinculação e a independência dos objetos sensíveis relativamente ao âmbito anímico se dão por diferentes perspectivas: a sonância e a atividade anônima da cor bem como à dos referentes às demais modalidades sensórias - estão inevitavelmente relacionadas à dimensão psicológica por estarem estruturadas de modo a corresponderem a um sentido específico, mas, ao mesmo tempo, não dependem do serem percebidas a fim de exercerem a atividade que lhes é própria.

\subsection{Aparência interna e aparência externa}

O realismo aristotélico quanto ao objeto sensível toca diretamente na questão da ocorrência da palavra "phantasía" no De Sensu, pois ilustra como é possível referir-se ao ente o qual se depara com uma imagem ou aparência e resguardar a realidade objetiva dessas últimas. Nada impede, assim, que a phantasía da cor esteja na própria coisa em si, constituindo uma noção diversa da phantasía enquanto função ou fenômeno anímico.

De qualquer forma, essa ocorrência diferencia-se daquelas que veiculam um sentido ligado à phantasía enquanto função anímica - seja tal sentido referente de modo direto a esta, seja relativo ao seu produto específico -, pois ela surge no contexto da análise do objeto da visão, não havendo qualquer referência à função imaginativa. Isso pode ser facilmente visualizado por meio da impossibilidade de se traduzir de forma coerente a ocorrência do termo em De Sensu 439 b6 por "imaginação". Caso se insista em interpretá-la com o mesmo sentido de phántasma, basta evidenciar o contexto da passagem, o qual certamente, na hipótese de se tratar ali do produto de uma faculdade anímica, não apontaria para o resultado do ato da função imaginativa, mas para o da sensação em sua modalidade visual. Além disso, o termo "phántasma" refere-se a aparências totalmente internalizadas, as quais, de maneira distinta da aparência da cor,

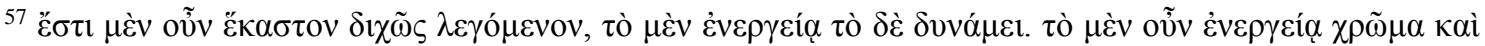

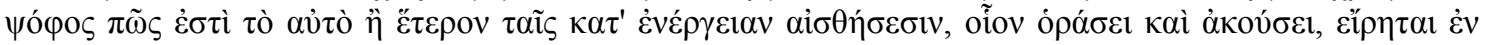

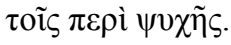


são exclusivas para o indivíduo - os phantásmata, enquanto produtos de uma função anímica, são "privados" -, e não representam a possibilidade de ênfase no aparecer da coisa, mas, ao contrário, indicam o ente sensitivo e/ou imaginativo como sede das aparências (WHITE, 1985, 487). Para fins de clarificação, basta notar que o acesso à phantasía da cor é disponível a qualquer indivíduo capaz de apreendê-la sensivelmente, o que não se dá no caso de fenômenos intrapsíquicos. Uma aparência, portanto, "pode tornar-se totalmente interiorizada, de modo que o polo subjetivo torna-se esmagadoramente predominante" (ibid., 487). Phántasma e phantasía, ao menos na comparação de passagens diversas em contexto, não são, absolutamente, sinônimos ${ }^{58}$.

\section{O CASO DO METEOROLOGICA}

Mesmo que o De Sensu 439b6 representasse uma ocorrência de sentido estritamente psicológico, ainda haveria a possibilidade de ali identificar uma noção diversa de phantasía, a bem dizer, a de uma phantasía "não imaginativa" - diferenciada das presentes no De Anima III por não referir-se à criação de imagens na ausência do objeto real - ou "visual"59. Os léxicos não ignoram esse sentido ligado à visibilidade, à aparência externa dos objetos vistos: sendo a phantasía, em primeira instância, referente à aparição das coisas, a modalidade sensória da visão possui a primazia no complexo

\footnotetext{
${ }^{58}$ Cabe ressaltar a não necessidade de se negar toda e qualquer relação entre ambos: "Por trás de qualquer ocorrência do complexo semântico associado à 'phantasía', sempre encontraremos o sentido de “aparição"”. (DÍAZ; LIVOV; SPANGENBERG, 2009, 32).

${ }^{59} \mathrm{Na}$ verdade, a noção de uma phantasía visual de modo algum representa inovação ou deturpação: "A phantasía, desde suas origens, não se refere exclusivamente a representações visuais, mas abrange tudo aquilo que surge da aparição, da apresentação de uma realidade exterior posta à luz. Denota o aparecer, a aparência, em um sentido suficientemente amplo como para referir-se a uma apresentação tanto à consciência como aos sentidos, seja esta imediata, como à memória, verdadeira ou ilusória. Os termos gregos que fazem referência a tal aparecer (phaínesthai, dokêin), como "parecer" na nossa língua, têm assim uma dupla acepção, podendo assumir tanto um sentido diretamente sensorial ("isso parecer vermelho") quanto um não sensorial, cognitivo, mediante o qual expressamos aquilo a que estamos inclinados a crer ("esse homem parece honesto"). Essa é uma das razões pelas quais se recorre por vezes à grafia “(a)parece”. O alcance da phantasía estende-se, assim, muito além do que o possivelmente sugerido pela sua estreita associação com os objetos dos sentidos." (MARCOS, 2009, 12-13). A phantasía visual, historicamente, não é precedida pela phantasía imaginativa: "A phantasía abarcava tudo aquilo que surge da aparição, da apresentação, tanto à consciência como aos sentidos, de uma realidade exterior posta à luz." (DÍAZ; LIVOV; SPANGENBERG, 2009, 29). Dessa forma, muito antes de a phantasía como faculdade imaginativa desvirtuar-se na ideia romântica de imaginação criativa (WATSON, 1999, x), alargaram-se os limites da extensão do termo para abarcar, além de aparências externas e mistas (internas, mas com alguma referência externa), as aparências puramente interiores.
} 
semântico do termo analisado, apesar de não deter, de maneira alguma, seu monopólio ${ }^{60}$.

O termo "phantasía" ligado à cor, apesar de ocorrer no conjunto de tratados psicológicos de Aristóteles uma única vez, constituindo, à primeira vista, uma espécie de exceção, não é ausente no restante do corpus. O Meteorologica, um dos trabalhos cosmológicos do filósofo, contém quatro ocorrências da palavra em contextos referentes às cores, afora três outras relativas a fenômenos celestes, as quais serão adiante analisadas. Ao tratar da reflexão das cores em superfícies espelhadas, ele afirma: “A cor das coisas brilhantes às vezes aparece brilhante, mas às vezes, seja pelo misturar-se com a cor do espelho, seja por conta da fraqueza da vista, produz a phantasía de outra cor." (Meteo., 372b, 7-9) ${ }^{61}$.

Torna-se patente, assim, a não acidentalidade da conexão do conceito com o objeto sensível da visão: a cada cor pertence uma phantasía distinta, um aspecto visível próprio, o qual a diferencia das demais, portadoras de outros aspectos. Tal afirmação é apoiada por outra passagem do Meteorologica, inserida nas considerações sobre a cor do fenômeno celeste do arco-íris: "Que tal é a cor, ficará claro, bem como a respeito da phantasía das outras cores, a partir disso." (Meteo., 374b, 8) ${ }^{62}$.

A ideia contida no de De Sensu acerca da não delimitação da phantasía das cores de coisas indeterminadas poderia, à primeira vista, junto com a ocorrência em Meteo. $372 \mathrm{~b} 9$ - a qual surge no relato de um fenômeno ligado à produção de uma phantasía não correspondente à do objeto real - servir de base para afirmar a conotação, por parte do termo phantasía enquanto atrelado às cores, de aparência ilusória. A seguinte passagem do Meteorologica parece condizer com tal modo de interpretar a palavra:

Tal afecção [i.e., o efeito de contraste] torna-se evidente também no caso das cores brilhantes: nas coisas tecidas e bordadas, as cores justapostas umas às outras muitíssimo diferem quanto à phantasía como o roxo nas lãs brancas ou pretas -, e também se estão sob esta ou aquela luz, razão pela qual os bordadores dizem errar com

\footnotetext{
${ }^{60}$ O Dicionário Grego-Português lista, na entrada dedicada à phantasía, as traduções "visão", "aparência exterior" e "aparência visual". As duas últimas, melhor que "aparência", captam o significado da phantasía atribuída à cor, e, como será visto adiante, da phantasía dos corpos celestes. O Greek-English Lexicon oferece como significado principal do termo a noção de aparência e, em especial, a aparência de imagens visuais. O léxico de Isidro Pereira, emblematicamente, lista em primeiro lugar as traduções "aparição" e "visão", e , somente no final da entrada, "imaginação".

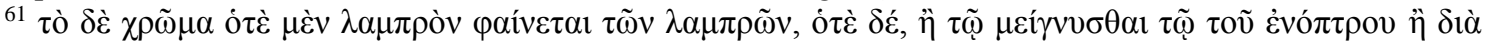

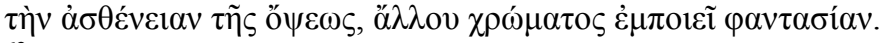

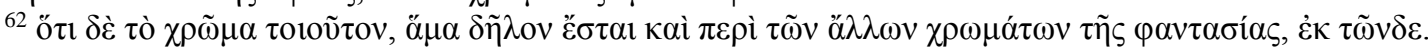


frequência as cores quando trabalham à luz de lamparina, usando umas em vez de outras. (Meteo., 375a, 23-28) ${ }^{63}$.

Aqui, apontam-se alguns elementos em função dos quais a phantasía de uma cor se altera, como a justaposição de cores e as diferenças em luminosidade. A phantasía, portanto, varia de acordo com as condições, podendo-se tornar enganosa, i.e., não correspondente ao aspecto apresentado em circunstâncias usuais.

Contudo, a phantasía das cores não está fundamentalmente ligada à ideia de aparência enganadora ou ilusão; tanto é que ela pode constituir um objeto de estudo genuíno, a respeito do qual é possível elaborar afirmações verdadeiras capazes, por sua vez, de garantir a verdade de outras asserções: "Se as coisas a respeito da phantasía das cores foram bem ditas, é necessário que ele [i.e., o arco-íris] possua três cores, e somente essas três [i.e., vermelho, verde e violeta]." (Meteo., 375a, 5-6) ${ }^{64}$.

Não obstante, mesmo estando comprovada a existência de um terceiro sentido, pode ser fecundo levar adiante sua análise. Nessa empreitada, outros textos do corpus revelam-se de grande auxílio.

\section{PHANTASÍA E CORPOS CELESTES: DE CAELO E METEOROLOGICA}

\subsection{A phantasía das estrelas}

Assim como o De Sensu, o De Caelo apresenta uma ocorrência de phantasía atribuída a um objeto real. Ao defender a forma esférica da Terra, Aristóteles invoca como testemunha a phantasía das estrelas ${ }^{65}$ :

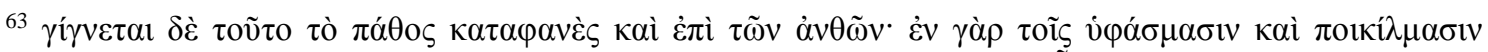

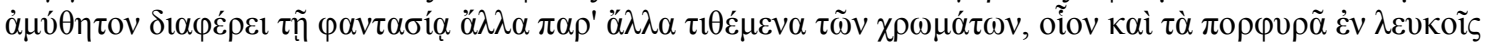

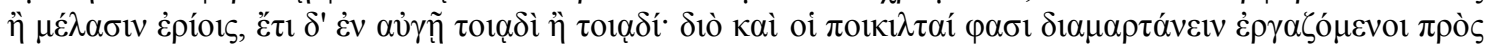

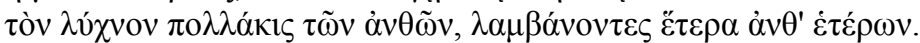

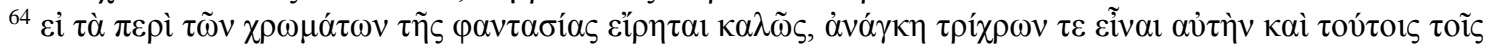

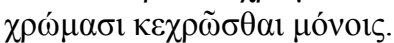

${ }^{65}$ Tal construção, por parte de Aristóteles, provavelmente remete aos primórdios do uso do verbo "phaínomai", nos quais era comum a forte referência às manifestações dos corpos celestes: "Os usos homéricos do verbo phaínomai testemunham sua estreita associação com o brilho do fogo ou com a aparição dos corpos celestes que brilham, e o próprio Aristóteles, em uma célebre passagem de $D A$ III 3 , 429a2-4, torna explícita a relação semântica entre phantasía e luz (pháos, phôs).” (MARCOS, 2009, 12). Há uma ênfase, no uso primitivo do mencionado verbo, na atividade da coisa que se manifesta: "Nos primeiros testemunhos com os quais contamos, os de Homero, prevalece amplamente o uso do verbo phainesthai no sentido de um aparecer perante os olhos. Em primeira instância, esse aparecer denota fundamentalmente um brilhar, e, por isso, vem associado, em geral, à aparição dos astros ou do fogo. (DÍAZ; LIVOV; SPANGENBERG, 2009, 32)." Enquanto associado à manifestação das coisas, o sentido da phantasía pende para a objetividade: "Nessa primeira instância, prevalece, pois, um sentido 'objetivo' e fortemente vinculado à vista: a coisa brilha e é por isso que a vemos." (ibid., 32).
} 
Por conta da phantasía das estrelas, claro está não apenas que a Terra possui forma esférica, mas também que ela não é grande em magnitude: ocorrendo a nós uma pequena mudança de posição para sul ou para norte, o círculo do horizonte claramente outro se torna, de modo que as estrelas sobre nossas cabeças mudam consideravelmente, e não aparecem iguais aos que se movem para o norte e aos que se movem para o sul: algumas estrelas são vistas no Egito e ao redor do Chipre, as quais não são vistas em locais ao norte, e estrelas que aparecem continuamente em terras nortenhas põem-se nos demais, de modo que claro está, a partir disso, não apenas que a forma da terra é esférica, mas também que ela não é uma esfera de grande magnitude. Caso contrário, alterações tão pequenas em posição não produziriam uma manifestação tão imediata. (De Caelo, 297b31-298a9) ${ }^{66}$.

Enquanto naquele tratado psicobiológico a phantasía era dita de um objeto sensível, pertencente à categoria da qualidade, aqui ela surge atrelada a entes cuja realidade não depende de qualquer inerência. Ao falar da phantasía dos astros, o filósofo claramente dispensa o uso das considerações feitas no De Anima acerca do conceito em questão - basta utilizar também nesse caso o argumento da tradução incoerente: não há sentido algum em se falar de uma "imaginação das estrelas". Além disso, o contexto do De Caelo é ainda mais desvinculado de noções psicologizantes, uma vez que seu foco é voltado para fenômenos cosmológicos ${ }^{67}$.

\subsection{A phantasía como evidência}

Outro ponto crucial na diferenciação dessa ocorrência relativamente às definições do De Anima III é o fato de a phantasía no De Caelo constituir evidência para a verdade de hipóteses ${ }^{68}$. Na passagem supracitada, ela confirma não apenas a

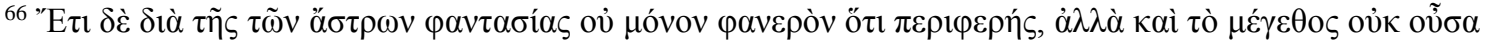

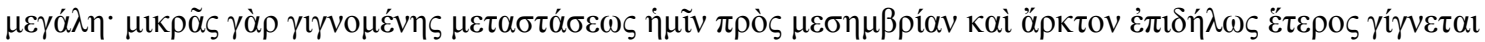

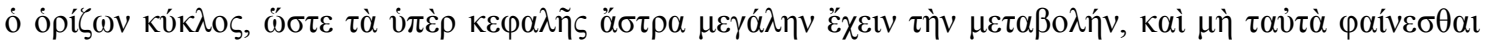

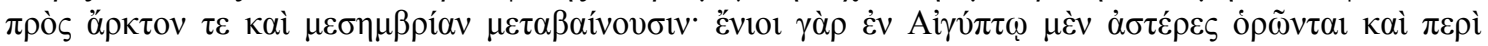

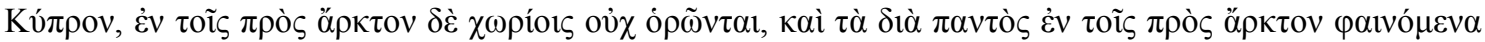

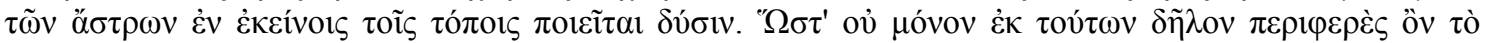

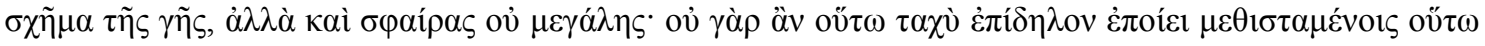

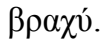

${ }^{67} \mathrm{O}$ afastamento da phantasía do De Caelo em relação aos desenvolvimentos e inovações do De Anima e demais escritos psicológicos não é novidade: Aristóteles utiliza o termo tanto em um sentido "objetivo", para descrever a espécie ou "aspecto" de algo, e em um sentido "subjetivo", para descrever a ação da alma ao capturar tal "aspecto". O primeiro sentido ocorre principalmente em seus escritos físicos, geralmente designando o "aspecto" de um dos corpos celestes ou de uma cor; o segundo uso é encontrado nos tratados psicológicos, e descreve certa ação pela qual a alma apresenta algo a si mesma. (WHITE, 1985, 486).

${ }^{68}$ Esse fato coaduna com a ideia de uma aparência não enganadora, a qual decorre do próprio ser da coisa manifesta: "Vale dizer que não cabe considerar a aparência forçosamente ocultadora do ser verdadeiro senão manifestação deste, isto é, um aparecer que não se contrapõe ao ser autêntico da coisa que aparece, mas que o revela." (MARCOS, 2009, 14-15).
} 
esfericidade da Terra, mas também sua magnitude não considerável. Tal suporte indica um caráter objetivo o qual dificilmente coaduna-se com a ideia de uma criação de imagens na ausência dos objetos reais. Na verdade, a espécie de phantasía encontrada no De Sensu e no De Caelo difere-se da função imaginativa e do produto desta também na questão da presença do objeto - nesses tratados, a phantasía nunca surge como imagem em ausência, mas sempre atrelada à coisa percebida.

A phantasía "em presença" surge sempre ligada não à função imaginativa, à phantasía "em ausência", mas à faculdade sensitiva. Nas linhas anteriores ao último trecho citado, Aristóteles faz referência aos fenômenos fornecidos pela sensação:

Também por meio dos fenômenos fornecidos pela sensação [obtêm-se evidências]: os eclipses lunares não apresentariam tais segmentos [caso a terra não fosse esférica], pois, de fato, em suas fases mensais ela adquire todo tipo de forma - ela torna-se reta, convexa e côncava , mas nos eclipses seu limite é sempre convexo, de modo que, se ela é eclipsada por conta da interposição da Terra, a causa da forma há de ser a circunferência da Terra, sendo esta esférica. (De Caelo, 297b, 23- 30$)^{69}$.

Subentende-se, pois, a conexão da phantasía das estrelas com a modalidade sensória da visão, conexão essa partilhada também pela phantasía da cor, de modo que não apenas por estarem ligadas diretamente a objetos reais as ocorrências no De Caelo e no De Sensu relacionam-se entre si, mas também através da referência à sensação visual. De maneira alguma se deve negar à phantasía em ausência do De Anima referência à sensibilidade; contudo, as phantasíai daqueles tratados não são posteriores à sensação, mas apreendidas simultaneamente ao ato desta. Tal fato garante uma diferença em temporalidade: enquanto em ausência, a phantasía atualiza-se em momentos posteriores ao ato da sensação; enquanto em presença, porém, ela apresentase ao ente observador no instante da vista.

Em suma, portanto, há uma phantasía ligada não à imaginação, mas à faculdade sensível, e que pode, diferentemente da phantasía imaginativa, constituir evidência para a verdade de proposições científicas, como explicita o De Caelo, 297b31-298a9, ao atribuir à phantasía das estrelas - apreendida sensorialmente - um caráter elucidador relativamente à forma e à magnitude da Terra. Esse último aspecto poderia ser pensado

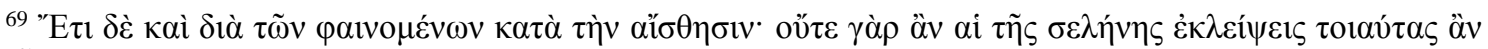

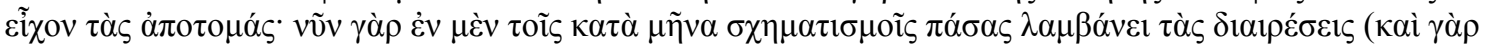

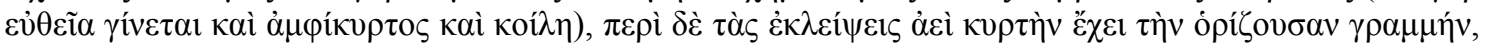

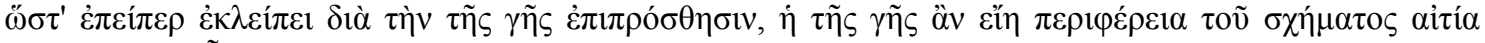

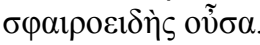


como um ponto diferenciador entre a ocorrência do De Sensu e a do De Caelo, dada a ausência de menção no primeiro ao uso da phantasía como indício científico. Todavia, também no De Sensu ela aparece ligada a fatos naturais, de maneira a tornar possível uma leitura da passagem capaz de aproximar ambas as ocorrências através não apenas da partilha de uma referência especial à sensibilidade, mas, inclusive, por meio da relevância na explicação de fenômenos: a phantasía da cor é evidência para a delimitação ou não delimitação daquilo no qual esta é inerente. De Sensu e De Caelo, portanto, apesar das enormes diferenças em contexto - de um lado, tem-se a psicologia satélite ao De Anima; do outro, a cosmologia -, e a despeito da diferença dos gêneros das coisas às quais o conceito aparece atrelado, apresentam um mesmo sentido de phantasía. O significado objetivo, o qual conota, a partir da raiz do termo, visibilidade, luminosidade e eventos celestes, é empregado por Aristóteles tanto nas linhas acerca dos astros quanto nas relativas às cores, na medida em que a phantasía, nesses casos, denota o "aspecto" próprio dos objetos visíveis (WHITE, 1985, 504).

Também no Meteorologica observam-se ocorrências desse sentido objetivo, denotador do aspecto visível da coisa observada. Lê-se ali, por exemplo, a expressão "phantasía da Via Láctea"70 ("têes toû gálaktos phantasías"):

Retomando então as teses iniciais e as definições feitas anteriormente, tratemos da phantasía da Via Láctea e dos cometas, bem como das outras coisas que calham de ser do mesmo tipo que estas (Meteo., 339a, 34-36 $)^{71}$.

O De Caelo, dessa forma, não constitui o único tratado no qual o termo aparece ligado a fenômenos celestes, fato esse que contribui para a estabilização do significado objetivo como uma possibilidade natural - múltiplas ocorrências da phantasía relativa ao aspecto dos objetos visíveis ${ }^{72}$ seriam indício de um hábito linguístico corrente, em contraposição a um uso anômalo da palavra.

\footnotetext{
70 A tradução de E.W. Webster (2006) claramente opta por desconsiderar a expressão presente no original: "Recordemos, primeiramente, nossos princípios originais e as distinções já traçadas, e então expliquemos a 'Via Láctea', os cometas e os outros fenômenos a estes aparentados".

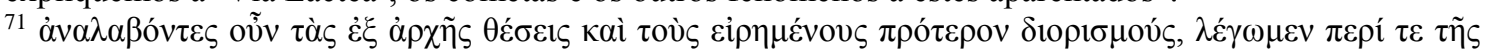

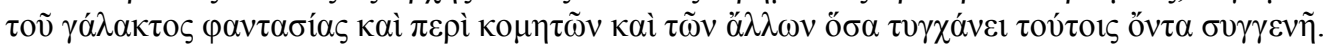

72 O Meteorologica contém outra passagem na qual o termo "phantasía" ocorre ligado a fenômenos celestes - traduzida mais ou menos literalmente, ela pode soar um tanto estranha: "Acerca das estrelas cadentes e das combustões, e também das aparências (phasmáton) que tornam rápidas as phantasíai, tais

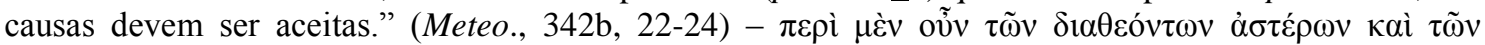

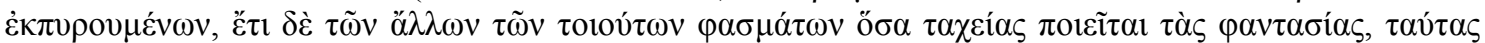

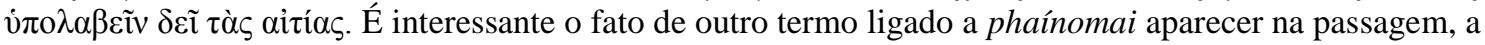
bem dizer, "phásma" ("aparição", "fantasma"). Ainda que uma tradução literal dê margem a problemas
} 


\title{
3.3. A phantasía como aparecimento
}

A outra ocorrência de phantasía associada a corpos celestes no Meteorologica denota apenas o aparecimento - em contraposição à ausência no céu visível:

\begin{abstract}
Alguns dos chamados pitagóricos dizem que ele [i.e., o cometa] é um dos planetas, mas que sua phantasía ocorre [é] em grandes intervalos de tempo, e sua ascensão é apenas um pouco acima da linha do horizonte, o que acontece também com Mercúrio - por conta de ascender apenas um pouco acima da linha do horizonte, muitas de suas fases escapam à vista, de modo que aparece em grandes intervalos de tempo." (Meteo., 342b, 31-35) ${ }^{73}$.
\end{abstract}

Aqui, apesar de o termo estar sendo veiculado dentro de uma expressão cuja forma é idêntica à daquelas em que ocorre enquanto designador do aspecto visual dos corpos celestes (phantasía + genitivo), ele refere-se à mera presença factual, não a traços qualitativos de uma apresentação visual específica - como é o caso das demais passagens até então consideradas. Contudo, apesar de essa ocorrência representar um significado diverso da palavra - phantasía enquanto simples presença ou aparição -, ela reforça ainda mais a ideia de uma objetividade ligada ao termo.

Enquanto referente ao evento da aparição do cometa no céu, o termo conecta-se ao posicionamento do objeto percebido, o que não pode indicar senão o altíssimo grau de objetividade expresso nessa noção de phantasía - basta observar a menção ao deslocamento do corpo celeste relativamente à linha do horizonte, ligando a ocorrência também ao tempo, uma vez que as linhas seguintes afirmam a proporcionalidade direta entre altura e frequência da aparição (Meteo., 342b, 34). O emprego do termo denota, pois, um fato puramente objetivo; a centralidade do objeto percebido torna-se também evidente nas linhas dedicadas à aparição de Mercúrio, expressa de maneira diversa - em vez de utilizar a forma substantivada, Aristóteles faz uso do verbo, tornando manifesta a ênfase no fato do aparecimento em determinado ponto, não enquanto atividade de ostentação de um aspecto específico, mas como mero estar presente - mero aparecer.

interpretativos - como, afinal, phásmata podem causar phantasíai? -, Aristóteles está simplesmente a fazer uma observação acerca da brevidade de certos fenômenos.

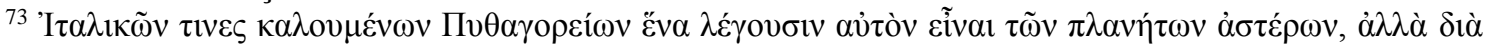

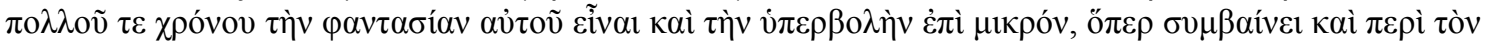

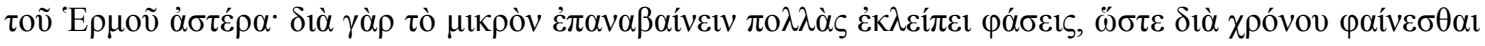
$\pi \mathrm{o} \lambda \lambda \mathrm{ov}$. 


\subsection{A phantasía como fenômeno}

Estabelecido o distanciamento entre as ocorrências analisadas e um sentido ligado à imaginação, procede-se agora à tentativa de afastá-las ainda mais de noções psicologizantes - até então, elas permanecem de certo modo conectadas ao universo da alma por meio do sentido da visão, apesar de estar clara a realidade independente dos objetos sensíveis. Pode não estar ainda suficientemente claro se é lícito falar de uma phantasía no próprio mundo, em contraposição a uma cuja realidade é meramente intrapsíquica, seja como faculdade ou função, seja como fenômeno anímico decorrente de uma destas.

O De Caelo apresenta outra passagem na qual o termo "phantasía" ocorre. O contexto é o mesmo do da passagem supracitada, qual seja, o da discussão a respeito da forma da Terra. Contudo, ela não será dita aqui de algo como o foi nas passagens já analisadas, mas aparecerá no enunciado absolutamente, referindo-se a um efeito decorrente de condições objetivas precisas:

De maneira parecida, há também discordância acerca da forma da Terra: a alguns parece ser esférica; a outros, plana e da forma de um tambor. Estes utilizam como evidência o fato de o Sol, ao pôr-se e ao nascer, exibe, ao ser ocultado pela Terra, um desaparecimento reto, não esférico, enquanto que, fosse a Terra esférica, o corte teria que ser esférico. Eles não levam em consideração a distância entre o sol e a Terra nem o tamanho da circunferência - no caso de círculos que parecem pequenos, o corte parece, a distância, ser reto. Por conta dessa phantasía, eles não devem duvidar que a massa da terra é esférica; contudo, ainda insistem, dizendo que por causa de sua imobilidade ela deve ter a outra forma. (De Caelo, 293b35-294a10) ${ }^{74}$.

Nessa passagem, a phantasía é ela própria o fenômeno ${ }^{75}$ proveniente da sobreposição de um objeto esférico de magnitude não considerável e da distância entre sobreposto e sobrepositor; ela é, assim, a aparência de aspecto retilíneo do corte, a qual constitui a decorrência dessas condições precisas. Também é digno de nota o fato de tal phantasía, assim como na outra ocorrência do termo no De Caelo, constituir evidência para a verdade da hipótese relativa à esfericidade da Terra.

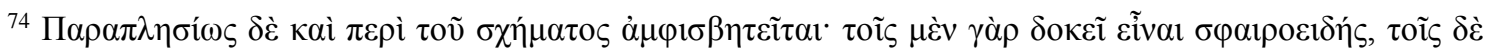

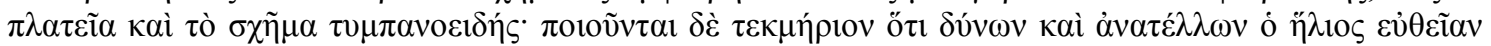

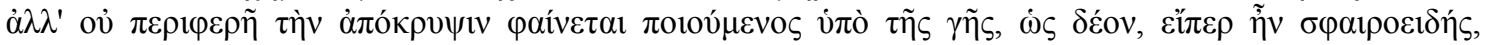

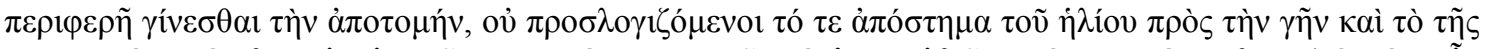

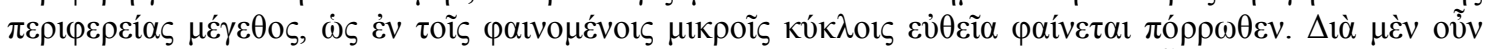

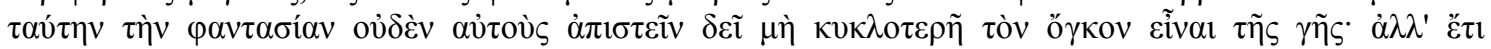

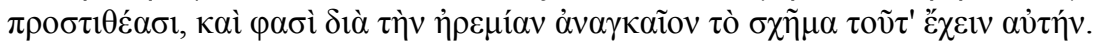

${ }^{75}$ Guthrie (1971) traduz a ocorrência por "fenômeno"; Stocks (1922) opta por "aparência", um termo mais psicologizante.
} 
O De Caelo $294 \mathrm{a} 7$ permite visualizar, melhor do que nas duas ocorrências pouco antes consideradas, como a phantasía pode adquirir uma conotação não psicológica. Se naquelas ainda permanecia alguma dúvida quanto à realidade do sentido objetivo, aqui tal hesitação não deve perdurar. Fenômenos como o aspecto retilíneo provindo da sobreposição de uma superfície esférica sobre outra nos casos de longa distância entre elas estão no próprio mundo, possuindo uma gama de causas objetivas. Obviamente, não há de ser excluída a perspectiva do observador ${ }^{76}$ - afinal, o aspecto da sobreposição poderia em princípio variar; contudo, ainda que essa espécie de phantasía represente, do ponto de vista da faculdade sensitiva, um fenômeno enganador acerca das reais propriedades do objeto observado, isso não basta para reduzi-la a algo meramente intrapsíquico $^{77}$. O efeito de não esfericidade na sobreposição e o sol da magnitude de um pé, por exemplo, podem ludibriar o julgamento; de fato, é no engano da sensação que certas phantasíai desse tipo surgem diante do ente observador. Todavia, é necessário focar no tanto de objetivo existente em tais manifestações.

Em suma, as ocorrências de "phantasía" no De Caelo 294a7 - e, na mesma linha de argumento, também a passagem no De Anima III a respeito da aparência do sol $^{78}$ tornam evidente a incoerência de se considerar tais manifestações como fenômenos ancorados unicamente na dimensão psicológica do ente ao qual o objeto aparece. Primeiramente, nota-se como, apesar de representarem visualmente propriedades as quais não correspondem ao real estado de coisas, elas são explicáveis do ponto de vista objetivo - fatos como distância e magnitude explicam a aparência não condizente com o real $^{79}$. Em segundo lugar, uma vez consideradas todas as condições envolvidas,

\footnotetext{
${ }^{76}$ Não há como proceder a uma desvinculação total entre a phantasía e a perspectiva do ente sensitivo, mas tampouco - e nisso se ancora a presente tentativa de focar no outro aspecto do conceito - se pode fazê-lo em relação ao objeto: "Toda aparição coimplica um polo objetivo e um polo subjetivo." (DÍAZ; LIVOV; SPANGENBERG, 2009, 32).

${ }^{77}$ A phantasía não prescinde, em essência, da dimensão objetiva, o que lhe confere a possibilidade de ser um componente importante na relação entre ser humano e mundo enquanto, respectivamente, contemplador e contemplado, conhecedor e conhecido: "O conceito grego de phantasía se move em espaço que, da nossa perspectiva, não se pode reduzir exclusivamente ao campo de atividade de um sujeito, mas que envolve um componente receptivo fundamental, que estabelece uma continuidade objetivo-subjetiva. Essa estrutura semântica constitutivamente diádica distingue a phantasía como uma zona peculiar de intersecção entre o homem e o mundo.” (DÍAZ; LIVOV; SPANGENBERG, 2009, 30).

78 "Também aparecem coisas falsas, sobre as quais se tem ao mesmo tempo uma suposição correta; o Sol, por exemplo, aparece como medindo um pé, mas acredita-se ser maior que a Terra.” (DA III, 428b, 1-4).

${ }^{79} \mathrm{O}$ De Coloribus também é sensível quanto à influência de condições objetivas sobre a manifestação visual: "Todas as coisas a partir das quais a luz fortemente refletida é escassa aparecem como negras. É por conta disso que as sombras aparecem como negras. Da mesma forma a água, quando agitada, como a agitação do mar: poucos raios de luz caindo e dissipando-se a luz por conta da aspereza da superfície, a parte que se encontra na sombra aparece como negra." (De Coloribus, 791a, 18-23). Outra passagem desse mesmo tratado, na qual o autor menciona certa pedra cuja identidade não pode ser apontada por
} 
compreende-se a necessidade do aspecto observado: ele é uma decorrência de fatores interligados do real. Se assim não fosse, dificilmente esses fenômenos poderiam ser utilizados como evidência para a verdade de proposições científicas. Pela perspectiva unilateral da sensibilidade, tais phantasíai são de fato ilusões - e, como ditas na passagem do De Anima há pouco mencionada, falsas. Ao serem tratadas racional e holisticamente, i.e., ao terem suas causas reveladas, porém, elas podem auxiliar na constatação dos fatos, não obstante oporem-se, na superfície, ao real.

\section{O CASO DO DE COLORIBUS}

O De Coloribus, apesar de não ser da autoria de Aristóteles, insere-se na tradição imediatamente posterior a ele e herda sua nomenclatura ${ }^{80}$. Nesse tratado, o termo "phantasía" surge, assim como no De Sensu, dentro do contexto das cores, ou seja, em uma discussão cujo foco não é a diversidade dos fenômenos anímicos. Isso poderia indicar que o sentido da phantasía vinculada à cor era, no círculo intelectual do filósofo, bem estabelecido e não orbitava ao redor de um conceito pouco claro, o qual adquiria tonalidades obscuras quando deslocado do contexto dos estudos sobre a alma. Desse modo, a passagem isolada do De Sensu não constituiria uma anomalia ou indício de desleixo terminológico, mas, ao contrário, coaduna com um uso à época em voga.

Tratando das causas pelas quais emerge a coloração escura, o membro da escola peripatética e autor do De Coloribus escreve:

Ou o objeto visível é por natureza negro (pois a luz negra é refletida a partir de todos os objetos negros), ou pelos objetos a partir dos quais nenhuma luz é trazida às visões: o invisível, quando o local

\footnotetext{
conta da não preservação de seu nome no texto, também permite visualizar a relação entre phantasía e condições objetivas; tais pedras, diz o autor, "são pretas, mas produzem marcas brancas por conta de as composições originais de todas as coisas desse tipo serem a partir de partes negras pequenas e densas, mas, em sua formação, foram tingidos, com todos os poros pelos quais a tintura passou adquirindo

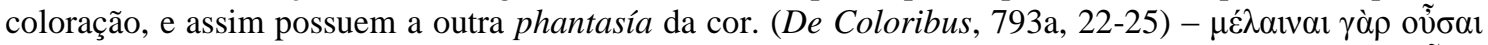

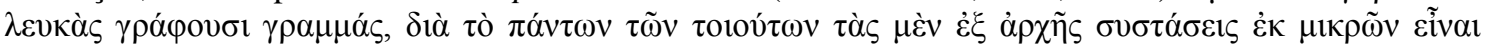

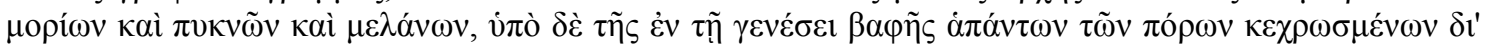

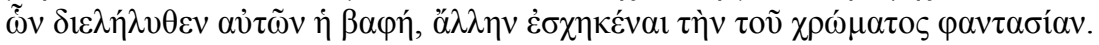

80 “O corpus Aristotélico inclui vários livros escritos não por Aristóteles, mas por membros de sua escola. Esses livros podem lançar muita luz sobre a história do pensamento peripatético, mas, por serem apenas razoavelmente interessantes em si mesmos, pouco trabalho foi feito sobre eles até agora. [...] Esse livro [i.e., o De Coloribus] oferece-nos uma visão excepcionalmente boa acerca dos métodos utilizados por um estudante peripatético da natureza e da atitude com a qual ele abordava seu tema." (GOTTSCHALK, 1964, 59).
} 
circundante é visto, produz a phantasía do negro. (De Coloribus, 791a, 13-17) ${ }^{81}$.

Nessa passagem, a phantasía da coloração escura parece equivaler à ideia de efeito cromático ${ }^{82}$ : no caso específico do objeto invisível inserido em um ambiente visível, é produzido o mesmo matiz dos corpos naturalmente escuros. Assim, tem-se uma só tonalidade, a qual emerge a partir de causas distintas.

O conceito cai, aqui, sob o mesmo significado da ocorrência no De Sensu, diferindo apenas quanto ao grau de generalidade, uma vez que se atrela a uma cor específica - no outro tratado, fala-se de modo geral acerca da phantasía da cor na totalidade dos corpos delimitados. Tal diferença, contudo, de modo algum constitui razão suficiente para tratar essas ocorrências como portadoras de sentidos distintos, pois ambas partilham de um contexto comum, a bem dizer, o do estudo do objeto da visão. Além disso, como se verá adiante, o tratado do discípulo de Aristóteles também contempla a noção de uma phantasía enquanto algo geral, atrelado ao próprio conceito de cor - a expressão "phantasía da cor" ou "das cores" não é estranha ao trabalho inautêntico acerca do objeto da visão ${ }^{83}$.

A mesma ideia aparece no De Coloribus 792a9, quando seu autor discorre sobre a derivação de diferentes cores a partir da presença mais ou menos significativa de seus componentes ou a partir de misturas específicas:

As outras cores, surgindo a partir destas pela mistura ou pela diferença em intensidade, produzem muitas e variadas phantasíai das cores. Conforme, por um lado, a diferença em intensidade de seus componentes, como no caso do carmesim e o roxo, ou, por outro lado, conforme a mistura, como no caso do branco e do preto, os quais,

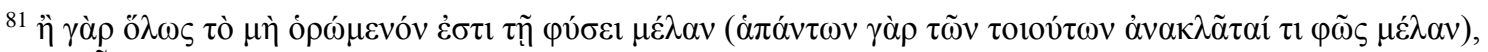

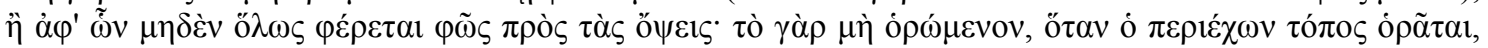

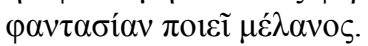

${ }^{82}$ Há outra passagem na qual a phantasía parece equivaler à ideia de efeito cromático: "É necessário investigar todas as diferenças das cores segundo o modo apresentado, tomando a semelhança, a partir do movimento, de acordo com o próprio fenômeno, comparando as misturas de cada um nos casos particulares em que se produz, em alguma geração e mistura, phantasía, e verificar a crença. (De

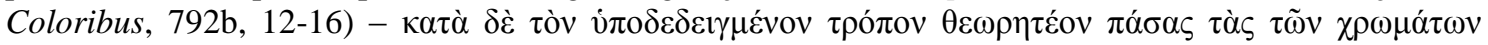

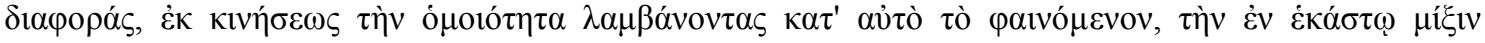

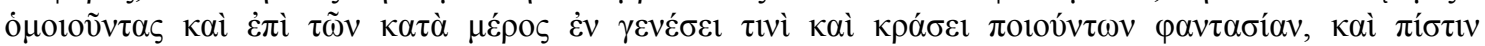

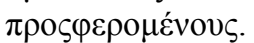

A phantasía pode resultar, de acordo com o autor do De Coloribus, da origem de uma cor ou da mistura de certas cores. Loveday e Forster (1991) traduzem a ocorrência nessa passagem por "efeito cromático".

${ }^{83}$ Respectivamente, em De Coloribus 793a25 e 792a9.
} 
quando misturados, produzem a phantasía do cinza. (De Coloribus, $792 \mathrm{a}, 5-9)^{84}$.

Nesse trecho, leem-se as expressões "phantasías chromáton" (phantasíai das cores) e "phaiô̂ phantasían" (phantasía do cinza). Ambas recaem sob o mesmo significado da passagem do De Sensu, e contribuem para consolidar a phantasía como um conceito intimamente ligado à teoria das cores: a cada coloração corresponde uma phantasía específica.

Apesar de nele não se encontrar definição alguma do que vem a ser a phantasía da cor, o De Coloribus revela-se bastante mais informativo com relação à ideia, uma vez comparado com o De Sensu. É sabida, por meio daquele, a conexão entre o conceito e a própria visibilidade das coisas: "De fato, não é por outra coisa que não pela luz que sua [i.e., do fogo] visibilidade calha de vir a ser, assim como a de todos os outros corpos ocorre pela phantasía do corpo. (De Coloribus, 791b, 16-17) ${ }^{85}$.

É graças à phantasía do corpo, portanto, que o objeto torna-se visualmente perceptível; em outras palavras, há a vista do corpo somente na manifestação de sua $\operatorname{cor}^{86}$. Nessa passagem em particular, o significado do termo parece ser mais restrito, dada a referência às colorações: a phantasía dos astros no De Caelo e a menção ao sol da magnitude de um pé no De Anima, diferentemente, não se refere de modo direto à cor - no caso do De Caelo, menciona-se a simples possibilidade ou impossibilidade de os astros serem visualizados a partir de determinadas posições, e, no De Anima, o tamanho aparente do sol ${ }^{87}$.

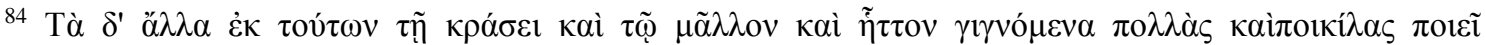

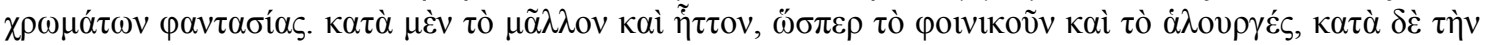

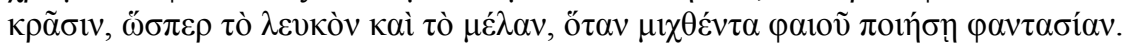

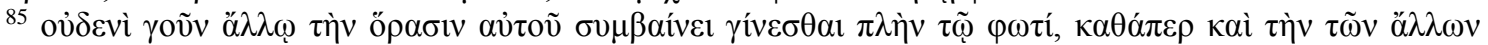

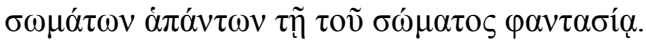

${ }^{86}$ Loveday e Forster (1991) assim traduzem a passagem supracitada: "É apenas pelo auxílio da luz que o fogo torna-se visível, assim como todos os outros objetos são tornados visíveis pela aparência de sua cor." A phantasía do corpo, dessa forma, refere-se à manifestação de sua cor. Tal escolha é claramente motivada pelo dito a respeito da visibilidade do fogo, a qual se dá por meio da luz: sendo esta a cor do fogo - "Que a luz é a cor do fogo, claro está a partir de não ser ele descoberto como tendo outra cor que não aquela, e por conta de somente ele tornar-se visível por si mesmo, enquanto as outras coisas tornam-

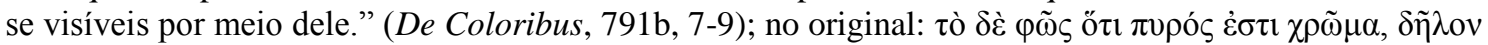

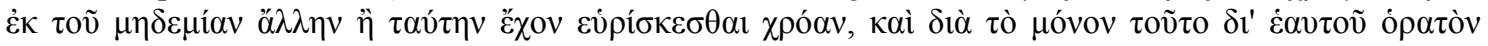

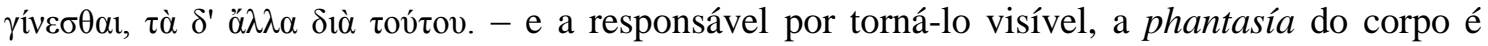
interpretada como manifestação da cor. Contudo, o texto traz somente a expressão "phantasía do corpo".

${ }^{87}$ Aristóteles identifica tipos diversos de objetos sensíveis: "O objeto sensível é dito de três modos, dois dos quais dizemos perceber diretamente [kath'hautá], e um, por acidente [katà symbebekéós]. Daqueles dois, um é próprio a cada sentido, e o outro, comum a todos. Chamo de próprio o que não pode ser percebido por outro sentido, acerca do qual não é possível enganar-se - por exemplo, a visão é da cor, a audição, do som, e a gustação, do sabor. O tato possui muitas diferenças. Cada sentido, porém, discrimina 
O De Coloribus possui, ao todo, seis ocorrências do termo "phantasía", contabilizando cinco a mais em relação ao De Sensu. Em nenhuma das passagens daquele tratado nas quais ele ocorre, o conceito aparece com um dos sentidos ligados à função imaginativa. A frequência do sentido alternativo referente à manifestação das próprias coisas é seguramente um fator que contribui para sua consolidação; as várias ocorrências em um tratado composto por um membro de sua escola são evidências para a hipótese segundo a qual o significado extrapsicológico orbitante ao redor da palavra helênica "phantasía" estava bem enraizado no pensamento transmitido pelo filósofo.

\section{A PHANTASÍA COMO MODO DE APRESENTAÇÃo}

Qual haveria de ser, por fim, a melhor maneira de definir essa espécie sui generis de phantasía? Levando-se em conta as considerações feitas acima acerca de sua ancoragem no plano da realidade, ela pode coerentemente ser entendida como o modo de apresentação de algo - seja de um objeto sensível ou de um astro, seja do resultado de determinadas relações entre objetos. $\mathrm{O}$ modo de apresentação ${ }^{88}$ é determinado não

\footnotetext{
a respeito de seus objetos próprios, e não se engana que tal coisa é cor ou som, mas quanto ao que é a coisa dotada de cor ou quanto a sua localização, ou quanto ao que é o sonante ou onde ele se encontra. Esses, por um lado, são próprios a um sentido específico; já o movimento, o repouso, o número, a forma e a magnitude são comuns: eles não são próprios a nenhum sentido, mas comuns a todos. Por exemplo, um

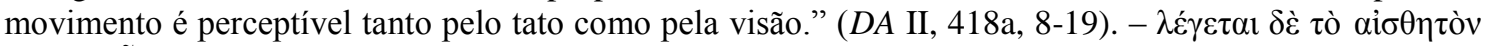

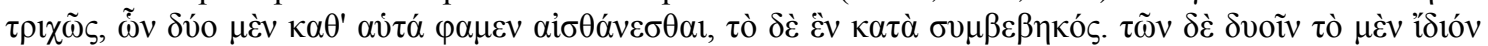

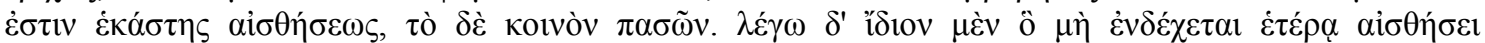

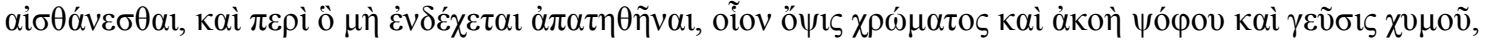

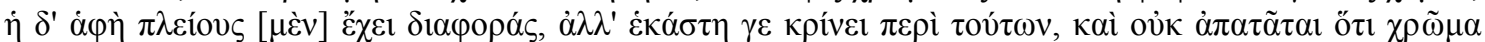

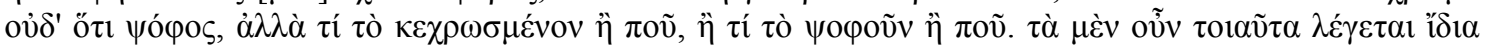

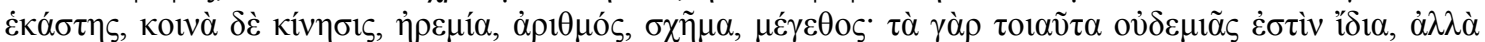

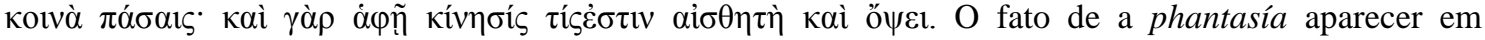
contextos referentes à visibilidade em geral e a um dos sensíveis comuns (magnitude) estreita sua relação com a faculdade sensitiva na modalidade da visão, de modo que ela não está ligada apenas ao sensível próprio a esta, apesar de expressões como "phantasía da magnitude" não serem encontradas em lugar algum do corpus. Como observa White (1985, 504), a phantasía das ocorrências celestiais pode dizer respeito a seu brilho, figura, rapidez e, em suma, a qualquer aspecto apresentado aos observadores terrestres.

${ }^{88}$ A etimologia dos termos vinculados à phantasía atesta a plausibilidade dessa interpretação: "Do ponto de vista da morfologia histórica, é importante ressaltar o acentuado vínculo mantido pelos termos 'phaíno' - do qual havíamos dito ser derivado 'phantasía' -, 'pháos' (luz) e 'phemî' (dizer, declarar). Foi estabelecida, com certeza, uma raiz - $\mathrm{fa} F$ que se relaciona com um termo sânscrito que significa "brilhar", e outro que significa "luz”. Essa glosa parece supor um '*fa-mi' atemático, 'brilhar', que é o mesmo verbo que 'phemí. Os três termos, 'pháos', 'pháinọ' e 'phemí', são construídos sobre a mesma base do indo-europeu. Essa raiz envolve certa ambivalência semântica, pois significa tanto 'brilhar' quando 'declarar', 'expor', 'dizer', ambivalência essa que se transfere de certo modo aos termos que a partir deles se constituem, por exemplo, 'phásis', que significa tanto 'aparência' como 'declaração'; 'próphasis', 'primeira manifestação de uma doença' ou 'pretexto'; 'apophaíno', 'fazer aparecer' e 'declarar'; 'piphaúsko', 'fazer brilhar' e também 'explicar'. Entre os sentidos de 'phemê' também se encontram
} 
apenas pelo ente ao qual o objeto apresenta-se - i.e., pelo seu conjunto particular de faculdades discriminantes -, mas pela natureza da coisa em si: objetos distintos revelam-se em phantasíai distintas ${ }^{89}$.

A obra de Aristóteles testemunha, tanto na sua abordagem inovadora da função imaginativa como no seu trato da manifestação de fenômenos celestes e cores, não apenas a variedade de sentido da phantasía, mas também um movimento identificado por alguns comentadores como uma "progressiva subjetivação" do conceito - um desvio do âmbito visual, vinculado à coisa concreta captada pelos sentidos, para a dimensão mental, centrada na imagem forjada pelo indivíduo (DÍAZ; LIVOV; SPANGENBERG, 2009, 38). Tal deslocamento deixa-se entrever, nos escritos do Estagirita, nos usos espontâneos do termo em contextos não psicológicos e na abordagem canônica do De Anima III, 3, que indica o triunfo da dimensão interior ("subjetiva") da phantasía. Contudo, tanto quanto inovador, Aristóteles mostra-se herdeiro da tradição pré-filosófica, na qual a phantasía surge, primeiramente, como objetiva: em seus primórdios, ela tende à manifestação das coisas visíveis ${ }^{90}$, ao brilho, ao aparecer - em contraposição ao parecer.

Tal interpretação, que ambiciona apresentar o filósofo, a partir do uso de "phantasía" encontrado em seus escritos cosmológicos e nos contextos relativos à cor, como continuador de uma tradição linguística precedente, vai claramente de encontro à leitura de Nussbaum acerca do sentido de phantasía como "mera exibição" (NUSSBAUM, 1985, 253-354): segundo a comentadora, esses usos, cuja conexão com a ocorrência de phantásmata é inexistente, são entendidos por Aristóteles como representantes do sentido transferido ao qual se refere no De Anima 428a2, ou seja, a

'crer', 'pensar', 'imaginar' ('parecer', poderíamos incluir), assim como entre os de 'phaíno' figura 'declarar'." (DÍAZ; LIVOV; SPANGENBERG, 2009, 31).

89 "A Via Láctea, os cometas, as estrelas cadentes, os planetas, os relâmpagos e o arco-íris - todas as ocorrências celestiais que orientam o homem no cosmo - cada um possui sua phantasía ou 'aparência"'. (WHITE, 1985, 504).

90 "Nos termos de sua genealogia, 'phantasía' parece indicar o efeito de uma autoapresentação proeminente ou meramente notável de algo à vista, apesar de parecer haver adquirido rapidamente o significado amplo de "apresentação à consciência, imediata ou na memória, verdadeira ou ilusória". Assim, enquanto derivada de um termo referente ao espetáculo dos corpos celestes, 'phantasía' refere-se à manifestação de qualquer coisa perante o ser humano, talvez, de modo especial, uma exibição no sensível, e, acima de tudo, no mundo visível, mas também incluindo qualquer apresentação em sonhos, memórias, fantasias e ilusões. Em conjunto, a variedade de todas essas aparências forma a cena da dimensão pré-filosófica da experiência humana que precede e condiciona as questões subsequentes do homem acerca da verdade das coisas." (WHITE, 1985, 485). Poucos exemplos ilustram tão bem esse sentido como a ocorrência da expressão "periphainoménon" em um dos hinos homéricos: "Farei para ti um altar, sobre um cume visível de todas as partes (periphainoméno), e sacrificarei ricas oferendas para ti

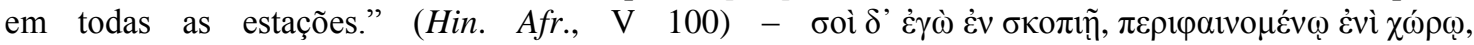

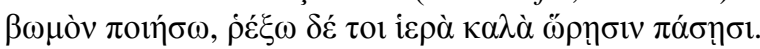


phantasía enquanto exibição possuiria um significado meramente metafórico (katà metaphorán), uma extrapolação dos limites do domínio original constituído pelo sentido básico ligado à "phaínetai" - verbo cujos usos a ele ligados formam a base do desenvolvimento semântico do termo - e referente aos phantásmata. Ora, que o sentido visual da phantasía não refira a phantásmata pode ser aceito sem qualquer consequência problemática: estes, afinal, são fenômenos completamente internalizados, contrastantes com a atividade externa de manifestação ostensiva. Contudo, a leitura de Nussbaum pressupõe a ausência de conexão entre o sentido visual de phantasía e o verbo phaínomai, opção interpretativa passível de ser facilmente refutada - o verbo remete não apenas à passividade caracterizadora da perspectiva do indivíduo, i.e., seu sentido não é exaurido por fatos representados pela forma na qual ocorre um verbo transitivo indireto ("parece a x que y"), mas também a acontecimentos expressos por meio do "aparecer" intransitivo ${ }^{91}$. Não é apropriado, portanto, descartar a existência de uma relação genuína entre a phantasía visual e a forma média de phaíno. Em seu fundo semântico encontram-se tanto os usos ligados a parecer, que fornecerão a matéria para o estabelecimento do sentido psicológico, quanto os relativos ao aparecer, ao ato de manifestação visual, de modo que não há evidência suficiente para priorizar a dimensão subjetiva em detrimento da outra. A primordialidade de um significado é incompatível com um uso metafórico, e o De Anima III.3, apesar de constituir um dos marcos da subjetivação do conceito, não abandona o uso intransitivo de phaínomai - o Sol, afinal, aparece, manifesta-se como possuindo a magnitude de um pé (DA III, 428b, 4). É improvável, assim, que a metáfora diga respeito à phantasía enquanto manifestação visual.

Em sua cosmologia, bem como na passagem isolada do De Sensu, o filósofo, ao empregar a palavra "phantasía" como modo de apresentação das coisas no mundo, permite entrever uma gama de características pontuais do conceito enquanto não ligado ao estudo das faculdades anímicas. Enumerando-se essas características, têm-se: 1) A ênfase na manifestação do ente revelado - em contraposição à atividade psíquica do indivíduo observador ${ }^{92}$; 2) Sua estreita ligação com a visibilidade; 3) Seu caráter

\footnotetext{
${ }^{91}$ No Dicionário Grego-Português, dentre as formas médias de "phaíno", além de ser listada a tradução "aparecer", encontram-se também "surgir" e "ser manifesto/evidente".

92 Essa ênfase remete a um momento da história etimológica do termo anterior à sua completa interiorização, a qual aponta para uma diferenciação radical entre sujeito e objeto: "O maior obstáculo epistemológico no momento de abordar a phantasía na Grécia antiga reside em sua real compreensão enquanto "imaginação" ou "fantasia" - como faculdade exclusivamente subjetiva. Ainda que possa assumir literalmente esse sentido [...], é imprescindível ter em vista o vínculo que o termo mantém com
} 
público - a phantasía, nesse sentido, é externa, podendo estar à disposição de qualquer um capaz de apreender visualmente o objeto.

Além dessas características, nota-se que a phantasía visual insere-se no plano da dinâmica ontológica da manifestação/ocultação do ser: os entes, ao manifestarem-se de um determinado modo, terminam por estar, à primeira vista, parcialmente ocultos nesse sentido, a magnitude dos corpos celestes jamais se revela à sensibilidade; contudo, o modo de manifestação dos astros relativamente à perspectiva do indivíduo observador, modo esse que não pode, por motivos diversos, engendrar um desvelamento total, é capaz de auxiliar na revelação de outros aspectos da realidade - como é o caso da esfericidade da Terra. Os casos mencionados no De Caelo mostram o quão pouco a perspectiva, no pensamento de Aristóteles, constitui um obstáculo à apreensão do real. A phantasía dos entes consiste sempre em uma declaração do ser.

Apesar de, ao se contemplar ambos os extremos do complexo de significados referente à phantasía, diferenças insuperáveis poderem ser notadas - o modo de apresentação de um corpo celeste ou de uma cor não pode jamais ser uma imaginação, assim como a esta não pode ser outorgada nenhum grau de independência em relação ao âmbito psíquico -, um termo tão específico deve ser capaz de garantir, a despeito da multiplicidade de significado, um núcleo semântico ao qual se refere qualquer uso que dele se faça. Faz-se mister a existência de um resquício de sentido que perpasse tanto o uso do vocábulo em sua acepção mais objetiva quanto em suas variações restritas ao domínio das faculdades da alma.

Se a phantasía diz respeito a qualquer tipo de aparição, e visto que ela é uma forma substantival correspondente ao verbo "phaínomai", o cerne ao redor do qual a totalidade de seus sentidos há de necessariamente orbitar é a ideia de aparecimento. Não apenas a phantasía objetiva das cores e dos corpos celestes indica uma aparição ao ente observador, mas também aquela cujo significado é estritamente psicológico: a phantasía enquanto phántasma não deixa de ser uma aparição ao ente, e, enquanto função anímica, surge como causa de aparências. Essas aparências são, ao contrário das mais visuais, totalmente interiorizadas; não obstante, elas também aparecem ao indivíduo. Toda phantasía, portanto, remete a um aparecer, dando-se a variação semântica de acordo com a coisa que aparece: se externa, tem-se uma phantasía objetiva, visual; se

todo um campo semântico no qual se inscreve, dentro do qual a forte distinção entre sujeito e objeto não havia sido ainda esboçada. (DÍAZ; LIVOV; SPANGENBERG, 2009, 29).” 
interna, tem-se um fenômeno psíquico, ou uma capacidade para produzir uma aparência interna.

Tendo sido expostos os principais tópicos sobre os quais se debruçaram os comentadores hodiernos no tocante à phantasía aristotélica, e já estando satisfatoriamente analisada a questão de seu sentido não psicológico, empreende-se, a seguir, a análise referente aos sentidos ainda não contemplados. A phantasía como faculdade anímica e a phantasía como produto desta (como fenômeno psíquico) são, assim, os temas abordados no terceiro capítulo. Tentar-se-á identificar em que medida Aristóteles permanece um herdeiro da tradição platônica, bem como os pontos de ruptura encontrados em sua abordagem acerca da phantasía. Ao término do capítulo seguinte, espera-se ter uma compreensão satisfatória acerca de cada um dos vários significados assumidos pelo termo na obra de Aristóteles. 


\title{
CAPÍTULO III: SENTIDOS PSICOLÓGICOS DA PHANTASÍA
}

\author{
No diálogo Sofista, Platão, através da personagem do Estrangeiro de Eleia, \\ define a phantasía ${ }^{93}$ como a opinião que ocorre por meio da sensação:
}

Quando, ao contrário, ela [a opinião] se apresenta, não mais espontaneamente, mas por intermédio da sensação, é acaso possível designar esta afecção por outra palavra que não "phantasía"? (Sof., $264 a)^{94}$.

Assim sendo, a phantasía platônica surge como uma noção complexa, cuja definição requer outros dois conceitos - opinião e sensação ${ }^{95}$. Em um estudo comparativo no qual se contemplam as noções aristotélica e platônica de phantasía a fim de ressaltar as semelhanças e as diferenças existentes entre ambas ${ }^{96}$, o texto do Sofista revela-se de inestimável valor.

Em primeiro lugar, observa-se, na passagem supracitada, o caráter discursivo da phantasía tal como concebida por Platão: sendo uma espécie de opinião, ela vincula-se necessariamente aos conceitos de discurso e pensamento (ibid.). Essa característica - a qual convém chamar de discursividade ${ }^{97}$ - é, como se pretende mostrar adiante, um dos

\footnotetext{
93 Marques $(2005,72)$ resume os instantes imediatamente anteriores ao aparecimento da noção de phantasía no texto de Platão: "O Estrangeiro lembra a Teeteto que eles haviam concordado que o sofista havia buscado refúgio na impossibilidade do discurso falso, dizendo que o falso não existe, o que ele justificava através da famosa tese segundo a qual ninguém pensa ou diz o não-ser, cuja condição seria, para o Estrangeiro, que o não-ser não participe do ser de nenhum modo. Ora, a análise que acabaram de fazer mostrou que o não-ser participa do ser (Sof., 258b-259b), o que deveria desarmar o sofista, a não ser que ele restrinja a ação do não-ser, que limite sua universalidade, dizendo que algumas formas participam do não-ser e outras não, o discurso e a opinião encontrando-se entre as últimas, Se o discurso e a opinião não se comunicam com o não-ser, não haverá nenhuma arte da produção de imagens, nem da produção de simulacros, exatamente o lugar onde haviam dito que se encontrava o sofista." Quanto à tradução do termo nas obras de Platão, Silverman (1991, 123) sugere "aparência". Já Bundy $(1922,362)$ opta por "imaginação".

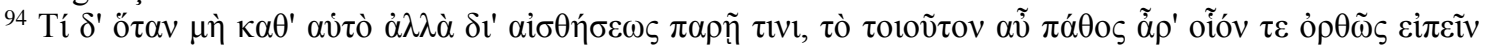

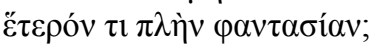

95 Acerca do propósito maior que orienta a introdução do conceito de phantasía no Sofista, afirma Marques $(2005,68)$ : "Sócrates pensa a phantasía na contraposição a Protágoras, fazendo a antilogia da antilogia. Ao contrapor-se desse modo, ele insiste que as phantasíai não sejam aceitas, sem mais, como verdadeiras. Portanto, trata-se de tomá-las como objeto de exame, como suscetíveis de serem inclusive refutadas. Essa tarefa é possível porque, no jogo de oposições entre as phantasíai e as opiniões dos interlocutores, há diferenças que superam a mera reciprocidade redutora que as toma indistintamente equivalentes. Para além do âmbito próprio e particular de cada sujeito da percepção, busca-se o âmbito maior do diálogo ou da contraposição de representações que devem poder ser contra-estabelecidas como justas ou falsas. Faz sentido, sim, dialetizar, isto é, examinar e refutar as representações uns dos outros.”

${ }^{96}$ Estudos comparativos podem ser feitos não somente entre a phantasía aristotélica e a tradição precedente, mas também entre aquela e filosofias posteriores. Blumenthal (1977), por exemplo, examina as leituras neoplatônicas do conceito aristotélico de phantasía.

${ }^{97}$ No Sofista, Platão reforça mais de uma vez a tese segundo a qual a phantasía consiste em uma das modalidades do discurso: "Portanto, visto que há tanto os discursos verdadeiros quanto o falsos, e que o raciocínio (diánoia) parece-nos ser o diálogo da alma consigo mesma acerca daqueles, a opinião, o
} 
principais pontos de divergência entre as concepções de Aristóteles e Platão acerca do tema.

Em segundo lugar, essas linhas do Sofista tornam explícita a origem sensorial da phantasía platônica, a qual tem a sensação como meio para sua ocorrência. O vínculo entre phantasía e sensibilidade representa, ao contrário da discursividade, um ponto de convergência entre as visões aristotélica e platônica relativas ao conceito, uma vez que também o Estagirita utiliza o conceito de sensação para explicar a phantasía, lançando mão de tal recurso para explicar tanto a origem quanto o funcionamento desta. No $D e$ Anima, lê-se: "A phantasía é diferente da sensação e do raciocínio. Não obstante, ela não ocorre sem sensação, e sem esta não há suposição." (DA III, 427b, 15-16) ${ }^{98}$.

A noção de sensibilidade, dessa forma, é um componente indispensável em ambas as definições de phantasía, não obstante o fato de Platão, diferentemente de Aristóteles, não tomá-la como a principal nota presente no enunciado resultante do esforço investigativo ${ }^{99}$, o qual tem por objetivo a captação efetiva de um importante elemento da realidade psíquica. A estreita ligação entre phantasía e sensibilidade é certamente uma herança platônica a qual pode ser observada nas obras psicológicas do Estagirita, apesar de não manifestar-se, na passagem de um autor a outro, nos mesmos termos, dada sua posterior radicalização. As veredas teórico-argumentativas através das quais tal radicalização é trazida à tona por Aristóteles estão suficientemente expostas na primeira parte do presente trabalho.

O terceiro ponto a ser observado na passagem pode, dependendo do contexto, representar tanto uma ruptura quanto uma continuidade do pensamento de Aristóteles relativamente ao exposto por seu mestre acerca da phantasía. Os termos nos quais se dá a ruptura não constituem propriamente uma novidade para quem se debruça hoje sobre a evolução do conceito na história da filosofia grega, tamanha foi a inovação levada a cabo por Aristóteles ao tratar a phantasía como uma função da alma. Contudo, algumas

resultado do raciocínio e o aparecer, aquilo que chamamos de mistura de sensação e opinião, é necessário que alguns destes, sendo todos parentes do discurso sejam, às vezes, falsos.” (Sof., 264a-264b) - Oủkoṽv

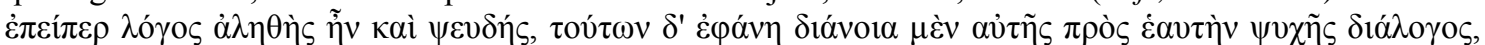

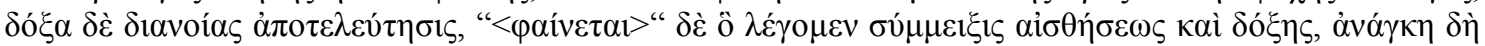

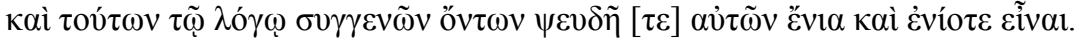

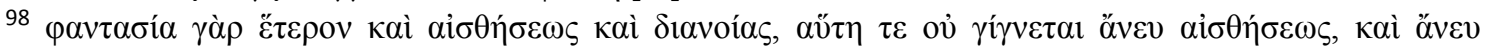

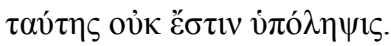

${ }^{99}$ Follon (2003, p. 11) nota que Platão, apesar de reconhecer a indispensabilidade do conceito de sensação para caracterizar a phantasía, define esta primariamente a partir do discurso: "É notável que, ao longo de toda essa discussão, a phantasía, mistura de sensação e de opinião, seja definida a partir não da sensação, mas da opinião, e, além da opinião mesma, a partir do discurso. A phantasía é, então, finalmente, um gênero do discurso." 
considerações relativas a aspectos da noção platônica rejeitados por Aristóteles fazemse aqui necessárias.

Ao tratar esta como um fenômeno psíquico em vez de uma faculdade bem delimitada, à qual corresponderia uma parte específica no complexo anímico, Platão deixa de realizar a inovação que possibilita, do ponto de vista da história das ideias, a referência direta do conceito hodierno de imaginação à phantasía grega ${ }^{100}$. De fato, não apenas o conteúdo da phantasía platônica torna inevitável a incompatibilidade entre seu conceito e a imaginação tal como ela veio a ser entendida posteriormente - a passagem do Sofista, ao estabelecer a dependência da phantasía relativamente a noções discursivas como linguagem e opinião, impossibilita a identificação entre aquela e fenômenos ligados à produção psíquico-imagética que não pressuponham seja um compromisso doxástico, seja uma mediação explicitamente linguística (tal como parece ser tradicionalmente concebido o modus operandi da imaginação) -, mas também sua natureza formal a afasta do conceito hodierno: enquanto este é construído em termos funcionais, referindo-se não tanto a fenômenos anímicos particulares quanto a uma capacidade da qual tais fenômenos se originam, aquela é concebida como referente a ocorrências no plano psíquico, não a uma função responsável por gerá-las. Nesse sentido, a phantasía platônica não atua: ela simplesmente acontece. Há, assim, uma assimetria inevitável entre o conceito a ela correspondente e a noção reelaborada de Aristóteles, uma vez que este eleva ao patamar de função algo antes considerado um mero fenômeno anímico singular.

De que modo, contudo, o fato de a phantasía platônica não designar uma função psíquica diferenciada pode indicar uma continuidade do pensamento de Aristóteles relativamente à visão de seu mestre? A abordagem do Estagirita, ao pressupor a diferença entre phantasía e phántasma $a^{101}$ - diferença referente à função e ao produto dessa função - não anuncia uma ruptura total com a ideia de uma phantasía enquanto estado ou afecção da alma, i.e., enquanto mero acontecimento no plano psíquico?

\footnotetext{
100 Tal inovação, como se sabe, é levada a cabo por Aristóteles. Apesar de o Estagirita não ter sido o responsável por introduzir o termo "phantasía" no vocabulário filosófico, ele o reelabora com o intuito de fazê-lo designar uma operação anímica diferenciada, indispensável para o pensamento e a ação humanos (DÍAZ, 2009, 169).

101 O DA III, 428a, 1 traz a descrição da phantasía como "aquilo pelo qual dizemos que nos ocorre uma

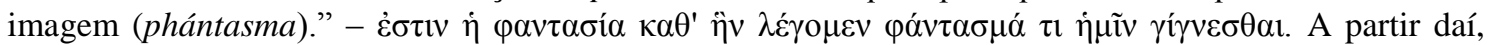
seria de se esperar que à designação do acontecimento psíquico (o produto da função descrita) fosse reservado o termo "phántasma", jamais "phantasía". Contudo, como será visto, há passagens no De Anima que não respeitam o estabelecido em 428a, 1.
} 
Sem dúvida, a phantasía nas obras de Aristóteles acerca da alma é tratada como uma função anímica, e a suposta predominância desse sentido evidenciaria o afastamento do filósofo relativamente à tradição que o precede. Todavia, ainda que Aristóteles de fato tenha tratado a phantasía como faculdade, há passagens em sua psicologia nas quais o termo não surge com o sentido de função anímica. Mesmo no De Anima III, onde o conceito é estudado em detalhe, é possível ler "a maioria das phantasíai são falsas" (DA III, 428a, 12) ${ }^{102} \mathrm{e}$ "os animais fazem muitas coisas de acordo com elas [i.e., as phantasíai]"103 (DA III, 429a, 6), bem como "a phantasía parece ser um tipo de movimento e não ocorrer sem percepção sensível" (DA III, 428b, 12) ${ }^{104}$. Além disso, o próprio uso do verbo "ocorrer" (gígnomai) atrelado ao termo "phantasía" - a exemplo da linha 427b16, acima reproduzida - convém muito mais a um fenômeno psíquico em sua mobilidade característica, indicada pelos estágios sucessivos de surgimento, desvanecimento e extinção, do que a uma faculdade anímica enquanto uma estrutura constante e sempre presente ${ }^{105}$.

Essas ocorrências não transmitem a noção de faculdade por meio da qual um fenômeno mental ocorre, senão a ideia mesma de fenômeno mental. Elas tornam o contraste entre phantasía enquanto faculdade e phántasma enquanto fenômeno mental bem menos claro do que se supõe, e mostram que o rompimento com a tradição precedente por parte de Aristóteles pode não se haver dado de maneira total.

O fato de Aristóteles utilizar o termo "phantasía" para designar, ao invés de uma função anímica, o produto ou resultado dessa função não é novidade na literatura secundária; tampouco o é sua intenção de referir-se, de um modo não ambíguo, a cada sentido possível fazendo uso de um termo diferenciado ${ }^{106}$. Contudo, parece que as causas prováveis dessa inconsistência não foram, até então, satisfatoriamente abordadas, nem se esboçou ainda sua devida problematização, talvez por conta tanto da magnitude

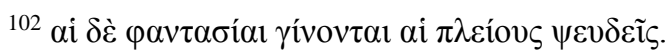

$103 . \pi 0 \lambda \lambda \grave{\alpha} \kappa \alpha \tau^{\prime} \alpha \hat{\tau} \tau \grave{\alpha} \varsigma \pi \rho \alpha ́ \tau \tau \varepsilon 1 \tau \grave{\alpha} \zeta \tilde{\varphi} \alpha$.

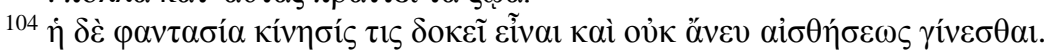

105 Cabe ainda notar que o verbo utilizado para indicar a presença de uma faculdade anímica é "pertencer" (hypárkhein): "A crença não pertence a nenhum dos animais não humanos, mas a phantasía, a muitos."

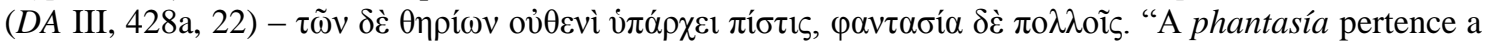

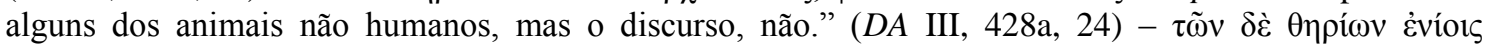

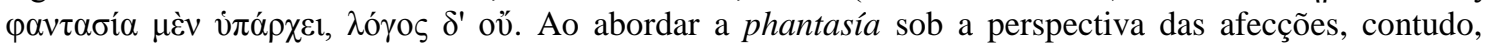
Aristóteles prefere lançar mão do verbo "ocorrer" (gígnomai): "É possível que um movimento ocorra pela

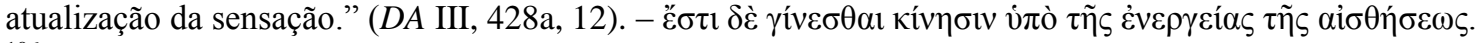
106 “'Phantasía' cumpre um dever triplo. O termo designa a capacidade, a atividade ou processo, e o produto ou resultado." (FREDE, 1999, 280). Para cada sentido, porém, há um termo específico: “Ao longo de seus escritos psicológicos, ele [Aristóteles] não apenas distingue com bastante cuidado entre capacidade, atividade e produto, mas, no caso da phantasía, ele frequentemente alterna para 'phántasma' a fim de designar o produto, e ocasionalmente usa 'phantastikón' para a capacidade.” (ibid., p. 281).
} 
da inovação Aristotélica, a qual forneceu os alicerces para as concepções posteriores de faculdade imaginativa, quanto do papel desempenhado pela phantasía no sistema aristotélico, onde pensamento e ação dela dependem para serem operacionalizados.

Justamente por apoiar-se sobre elementos considerados, em geral, de pouco relevo, para os quais não se encontra, no texto primário, suporte algum proveniente de uma elucidação intencional, a tese aqui delineada possui um caráter notadamente especulativo, pois assere a realidade de uma influência cuja verificação não se mostra factível. Contudo, apesar de a investigação não se desenrolar no plano da certeza, ela pode, debruçando-se sobre certas formas linguísticas e alguns dados históricos, estabelecer-se com segurança no nível das hipóteses satisfatoriamente corroboradas.

Platão tratou a phantasía como um páthos, i.e., como uma afecção - "tò toiûton â̂ páthos" ${ }^{107}$. Nesse sentido, a phantasía é um fenômeno psíquico, ou seja, um acontecimento que, enquanto tal, pode estar presente ou ausente na alma do indivíduo, a depender das circunstâncias, as quais podem gerá-lo ou vir a impedir sua formação. Aristóteles, curiosamente, apesar de incluir a phantasía na classe das funções anímicas, parece, por vezes, seguir a tendência do mestre, na medida em que se refere àquela também como uma afecção. No De Anima $427 \mathrm{~b} 18^{108}$, ao abordar as diferenças entre opinião e phantasía, ele afirma: "tal afecção encontra-se sob nosso controle."

O uso, no De Anima, do termo "afecção" para qualificar a phantasía anuncia uma dívida muito mais profunda com a obra de Platão do que aquela antevista pela conexão necessária entre phantasía e sensibilidade. Enquanto esse último vínculo efetiva-se no plano do conteúdo específico do conceito, o emprego da noção de afecção dá-se no contexto do próprio lugar categorial da phantasía, posicionando-a em um gênero determinado. O tratamento desta como um páthos, na obra de Aristóteles, evidencia uma continuidade muito mais arraigada do que a pressuposta pelo uso da noção de sensibilidade no De Anima III.3, pois através daquele é mantida a estrutura genérica do fenômeno. A frase expressa em 427b18, ao fazer ecoar tão audivelmente o Sofista de Platão, torna lícito, se não negar por completo a tese segundo a qual Aristóteles haveria efetuado o deslocamento categorial da noção de phantasía, ao menos relativizá-la.

107 "Ela é uma afecção que se torna presente na alma, com a relação a alguma outra coisa." (MARQUES, 2005, 76).

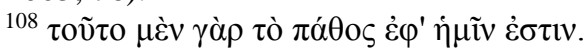


A definição fornecida em 429a2, ao posicionar a phantasía na classe dos movimentos, evidencia que o enunciado em 427 b18 não representa um lapso, pois, para Aristóteles, a ideia de páthos está indissociavelmente relacionada ao movimento percorrido pela alma (Oele, 2007, 153). Afecções consistem, assim, em movimentos intrapsíquicos.

Se é razoável supor a existência de um deslocamento categorial do fenômeno da phantasía a partir da obra de Aristóteles, tal ressignificação não se efetua através da transposição daquela para uma classe supostamente sem vínculo com o domínio das afecções, mas por meio do deslocamento do gênero afecção para um nível ainda mais próximo da espécie phantasía. Em Platão, o gênero próximo da phantasía é a opinião, sendo a afecção um dos seus gêneros superiores - a opinião, ao menos enquanto causada pela sensação, é tratada como uma das espécies englobadas pelo gênero afecção. Aristóteles, ao removê-la do conjunto das opiniões ${ }^{109}$, mantém-na na classe das afecções, utilizando o conceito de afecção para expressar seu gênero próximo. Do ponto de vista da categorização da phantasía na passagem do sistema platônico para o sistema aristotélico, não houve, em momento algum, um deslocamento do fenômeno para fora da classe das afecções, mas, antes, a recusa em se aceitar um gênero intermediário entre o gênero afecção e a espécie phantasía.

Digno de nota é também o fato de que a tradição dos comentadores peripatéticos parece haver tratado com naturalidade o caráter passional da phantasía aristotélica. Em sua paráfrase ao De Anima, Temístio $(163,14)$ reproduz ipsis litteris a expressão utilizada em $427 \mathrm{~b} 18^{110}$. Pouco adiante, abordando o contraste existente entre opinião e phantasía, o comentador relembra o caráter discursivo da faculdade doxástica: "a opinião é uma disposição discursiva." $(166,19)^{111}$

\section{PHANTASÍA E MOVIMENTO NA TERMINOLOGIA DO DE ANIMA}

A diferenciação entre parte (ou faculdade) da alma, atividade anímica e objeto é apresentada logo no início do De Anima I, quando Aristóteles indaga sobre o ponto de

\footnotetext{
${ }^{109}$ Para Aristóteles, a phantasía "não envolve juízo algum, não possui um caráter judicativo na medida em que não implica assentimento." (DÍAZ; MARCOS, 2003, 239). Diferentemente de seu mestre, o Estagirita traça uma "linha nítida" entre o âmbito dos juízos e o âmbito das impressões sensíveis (BARNEY, 1992, 294).

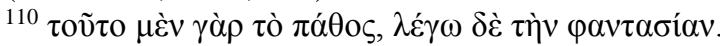

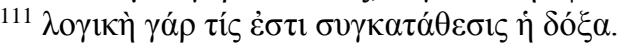


partida apropriado para a investigação relativa à alma. No plano da linguagem, tal diferenciação é expressa através do uso de formas linguísticas variadas: construções diversas correspondem, de um modo aparentemente rígido e consistente - a julgar pela manutenção dos padrões referenciais ao longo do trecho abaixo reproduzido -, a entidades e fenômenos efetivamente distintos entre si. Tão premente é o reconhecimento da efetividade das diferenças entre parte, operação e objeto, que o próprio curso da investigação demanda uma ordem temporal baseada naquelas: apesar de inegavelmente inter-relacionados e potencialmente interdefiníveis, tais entidades e fenômenos requerem, a fim de lhes corresponderem algum entendimento, análises específicas:

Também é difícil delimitar quais tipos diferem em natureza uns dos outros, e se é necessário investigar primeiro as partes (mória) ou suas atividades (erga); por exemplo, o inteligir (tò noeîn) ou o intelecto (tòn noûn), o sentir (tò aisthánesthai) ou a parte sensitiva (tò aisthetikón), e igualmente para os demais casos. Se é necessário investigar primeiro as operações, segue-se a aporia a respeito da necessidade de investigar os objetos (tà antikeímena) antes das partes; por exemplo, o objeto sensível (tó aisthêtón) antes da parte que sente, e o objeto inteligível (tò noẹtón) antes do intelecto. (DA I, 402b, 11$16)^{112}$

Todavia, não apenas a existência da diferença entre parte, atividade e objeto e seu reconhecimento por parte de Aristóteles - este já sendo um lugar-comum no contexto dos estudos de suas obras psicológicas - fazem-se relevantes para o estudo do alcance e pluralidade semânticos de um termo, mas também o modo como o filósofo ensaia, em seu texto, a apresentação das diferenças através das formas linguísticas que lhe eram disponíveis. No intuito de compreender-se a apropriação por parte de Aristóteles do item lexical "phantasía" - os fatos, respectivamente, de Platão figurar como pioneiro no tocante ao uso do termo e de Aristóteles haver-se familiarizado com a noção platônica de phantasía (como evidencia a crítica dirigida contra esta no $D e$ Anima) permitem falar de apropriação -, faz-se mister desdobrar as minúcias terminológicas introduzidas pelo filósofo, uma vez que elas constituem o solo no qual a mencionada apropriação encontra seu ambiente e floresce. Em outras palavras, o surgimento da phantasía aristotélica não se dá no vácuo - seja no vácuo da suposta

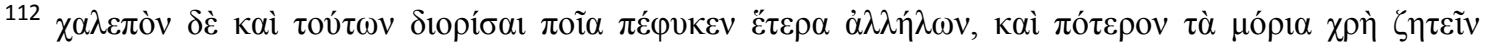

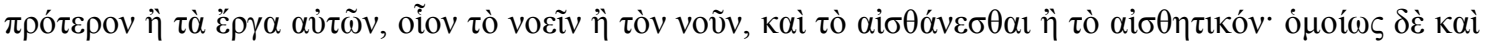

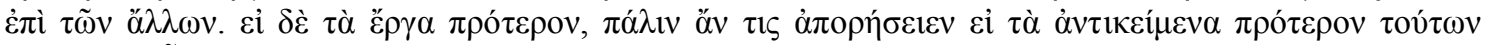

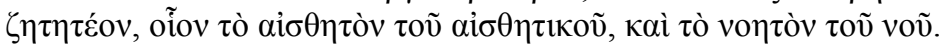


originalidade total, denunciado pela ausência absoluta de influências provindas da tradição precedente, seja o vazio da falta de um esquema nocional prévio e singular, o qual inibe, ab initio, qualquer criação ou apropriação de conceitos -, mas, ao contrário, insere-se em uma rede discursiva cuja estrutura há de vir à tona caso se objetive decifrar seus movimentos e flutuações.

\subsection{Formas linguísticas e conceitos psicológicos}

A primeira distinção interessante traçada na passagem supracitada é aquela entre parte e atividade (cabe notar que a dificuldade de delimitação apontada pelo filósofo refere-se às diferenças mútuas entre as partes, não entre estas e outra categoria de fenômeno ou estrutura psíquicos). As atividades são denotadas por meio da nominalização de verbos - "o inteligir" (tò noeîn), "o sentir" (tò aisthánesthai); a denotação das partes, por vez, ocorre através da nominalização de um adjetivo - como é o caso de "parte sensível" (tò aisthetikón, i.e., "aquilo capaz de sentir") - ou do emprego de um substantivo já existente, como "intelecto" (nô̂s). A cada parte, portanto, corresponde uma atividade, havendo formas linguísticas específicas que refletem a diferença categorial em questão. Às partes e às operações correspondem, segundo o filósofo - e esta é a segunda distinção fundamental -, os objetos (tà antikeímena), dentre os quais se encontram o objeto sensível (tò aisthêtón) no caso da parte sensível e o objeto inteligível (tò noẹtón) no caso do intelecto. Também aqui é empregado o processo de nominalização - no caso, de adjetivos - , resultando em expressões traduzidas de modo mais preciso por "aquilo passível de ser sentido" e "aquilo passível de ser inteligido""113.

Poder-se-ia objetar que a distinção tríplice expressa ao longo de 402b11-16, por aparecer no contexto de uma indagação no início da obra, possui um caráter meramente provisório, não representando, assim, algo fundamental a ser mantido através do desenvolvimento do tratado. Para escapar a essa réplica, portanto, faz-se necessário o levantamento de outras passagens nas quais a diferenciação é pressuposta, de modo a

\footnotetext{
${ }^{113}$ Digno de nota é o fato de Platão, na República, ao construir sua teoria da alma tripartite, lançar mão desse mesmo recurso linguístico. Na visão platônica, a alma é dividida em três partes, nomeadamente: a parte calculativa (tò logistikón), a ardorosa (tò thymoeidés) e a apetitiva (tò epithymétikón) (Rep., 439d, 440e). Moss $(2008,3)$ observa que o termo "tò logistikón", apesar de comumente traduzido por "parte racional", encontra sua tradução literal na expressão "aquilo capaz de calcular". Já no começo do $D e$ Anima, portanto, nota-se, sob o ponto de vista da forma, a manutenção de um padrão já encontrado na abordagem platônica acerca do tema da alma.
} 
evidenciar o quanto as já mencionadas formas linguísticas estão arraigadas no texto de Aristóteles.

\subsection{Parte e atividade psíquica em outras passagens do De Anima}

De maior proveito para o presente intuito é o enfoque na diferença entre parte e atividade, considerando-se suficientemente bem estabelecida a especificidade dos objetos a elas correspondentes, seja por meio das considerações do De Anima II a respeito do objeto sensível, seja por meio da existência de escritos como o De Sensu e o De Coloribus, os quais tratam das entidades passíveis de serem assimilados por alguma função anímica. Ainda no De Anima I, lê-se, pois, trechos em que se mantém o paralelismo entre as formas linguísticas provenientes de nominalizações de adjetivos e as formas disponíveis em substantivos; em 408a13 ${ }^{114}$, por exemplo, pergunta o filósofo: "de qual parte deve-se supor serem o intelecto (noûn), a faculdade sensitiva (tò aisthetikón) e a faculdade desiderativa (orektikón) uma síntese?”. A menção à faculdade desiderativa, por se dar nos mesmos moldes já observados em 402b11-16 - i.e., a partir de um adjetivo nominalizado -, reforça o vínculo semântico entre expressões como "tò aisthetikón" e substantivos disponíveis para a designação de faculdades anímicas específicas, uma vez que se trata, agora, de um padrão recorrente.

Contemplando as abordagens da tradição precedente, o filósofo, muito antes de sua listagem das faculdades ou disposições críticas no terceiro livro do De Anima, na qual se encontram, dentre outras, o intelecto (DA III, 428a, 4), já deixava transparecer a profunda relação semântica entre as ideias de parte e função anímicas ${ }^{115}$, relação esta que, na ausência de elementos textuais a evidenciarem o contrário, não parece consistir senão em uma equivalência. "Parte" (mórion) e "faculdade" (dýnamis) possuem, assim,

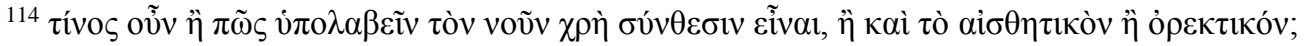

115 Além das expressões "parte" e "faculdade", Aristóteles utiliza "princípio" (arkhé) para se referir às estruturas intrapsíquicas responsáveis pelas operações dos seres vivos. Em uma passagem que evidencia a suposição, por parte do filósofo, da relação causal entre a posse dessas funções e as atividades realizadas pelos seres animados, a ideia de princípio é tida como equivalente à de parte (mórion): "O viver (tò sdênn) pertence aos seres vivos por conta desse princípio (dià tền archén taútên) [i.e., da nutrição], mas o animal constitui-se primordialmente pela sensação (dià tèn aísthesin). [...] Da sensação (aisthéseọs), pertence a todos, primeiramente, o tato. Assim como a faculdade sensitiva (tò threptikón) é capaz de separar-se do tato e de toda sensação (pásês aisthéseogs), o tato é capaz de separar-se dos demais sentidos (állon aisthéseon). Chamamos "faculdade nutritiva" (threptikón) à parte da alma (mórion têes psykhêes) possuída também pelas plantas; todos os animais parecem possuir o sentido do tato (413b, 1-10). É em virtude da posse de um desses princípios - a bem dizer, da nutrição, a faculdade anímica básica - que se dá o viver, fenômeno ali referido de acordo com o padrão linguístico de 402b11-16. Outra ocorrência do termo "princípio" enquanto referente a uma faculdade psíquica surge em 411b30: "Esse princípio [i.e., o nutritivo] é separável do princípio sensitivo (aisthêtikệs arkhêss), mas nada possui sensação (aísthesin) sem ele."
} 
no contexto da investigação acerca da alma, a mesma referência. Se em 402b11-16 é concebido o intelecto como uma parte da alma, em 404a30, sem a força de uma asserção categórica, lê-se que "ele [i.e., Demócrito] não trata o intelecto como uma faculdade (dynámei) voltada para a verdade.”. Já no De Anima I, portanto, o intelecto aparece como uma faculdade judicativa.

Dessa forma, se é possível conceber o intelecto não apenas como uma parte da alma, mas também como uma faculdade desta, segue-se que as expressões "tò aisthétikón" e "tò orektikón" - e qualquer outra construída a partir do mesmo processo-, por referirem-se a estruturas pertencentes à mesma categoria daquele, denotam também funções psíquicas, e não atividades ${ }^{116}$. O trecho seguinte, inserido, como 402b11-16, no contexto das considerações relativas às abordagens de filósofos precedentes sobre a temática da alma, reforça o paralelismo entre "noûs" e demais termos que tem por referência uma faculdade psíquica. A peculiaridade terminológica nele observada, apesar de sutilíssima, constitui evidência para a identidade nocional, no tocante à investigação sobre a alma, entre parte e função:

Obviamente quer ele [Platão] fazer da alma do mundo algo como o chamado intelecto (noûs), pois ela não é como a faculdade sensitiva (he aisthetiké) ou como a desiderativa (he epithymetiké), uma vez que o movimento destas não é circular. (DA I, 407a, 4-6) ${ }^{117}$.

Aqui, é possível observar o uso de expressões correlatas aos adjetivos nominalizados denotadores do mesmo tipo de estrutura à qual o termo "noûs" se refere. Todavia, apesar de também criadas pelo processo de substantivação, as expressões " $h \underline{e}$ aisthetikế" e "he epithymetikêe" diferem em gênero de "tò aisthêtikón" e "tò orektikón". Como consequência, uma vez que a palavra grega "mórion" é neutra, aquelas não

\footnotetext{
116 Por não ocorrer dentro dessas expressões o termo "dýnamis", qualquer tradução que o pressuponha implícito - como é o caso da tradução de Hett ("Of which of the parts, then, are we to suppose that the mind or the perceptive or appetitive faculty is a composition, and how is such a composition effected?") já indica um esforço de interpretação por meio do qual as partes da alma mencionadas em 402b11-16 são entendidas como faculdades psíquicas. A tradução de dos Reis, por sua vez, já é mais cautelosa: "De que e como, então, considerar o intelecto ser a necessária composição? E a parte que pode perceber ou a que pode desejar?". A opção por "parte" em vez de "faculdade" justificar-se-ia a partir do trecho 402b11-16, no qual o intelecto e aquilo capaz de sentir (tò aisthetikón) são tratados como partes (mória) da alma. De qualquer forma, mesmo essa última opção, ancorada em passagens anteriores, decorre de um esforço interpretativo que extrapola os limites de uma possível tradução literal: o termo "parte", apesar de relacionar-se, no começo do tratado, à forma nominalizada "tò aisthêtikón", não ocorre na passagem traduzida. Lóio, assim como Hett, opta pelo termo "faculdade": "De que coisa, então, ou de que forma teríamos de admitir que o entendimento, ou a faculdade perceptiva, ou a desiderativa são a composição?".

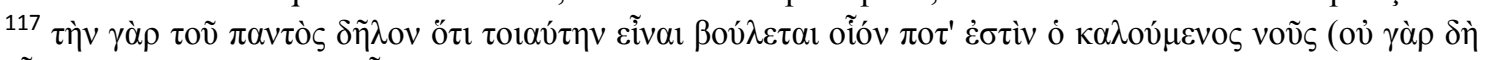

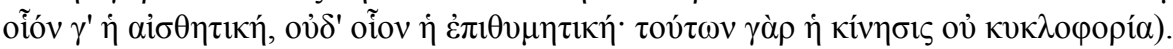


designariam, pelo menos de maneira direta, uma parte da alma, mas, diferentemente, uma faculdade (“dýnamis" é uma palavra feminina) ${ }^{118}$ Estando já estabelecido o paralelo entre o termo "noûs" e os adjetivos nominalizados do gênero neutro, poder-seia afirmar, sem afastar-se em demasia do fornecido pela evidência textual imediata, a equivalência de sentido entre essas formas e as expressões presentes em 407a5.

\subsection{Mais correlações entre formas linguísticas}

Além das passagens já citadas, o De Anima I contém outros trechos nos quais se evidencia o paralelismo entre o termo "noûs" e os adjetivos substantivados neutros. Tais trechos revelam-se importantes em virtude de representarem a manutenção, ao longo do texto, das diferenças categoriais esboçadas em 402b, 11-16. Um deles, ainda no contexto da análise das opiniões precedentes, aponta para o problema de se tentar derivar o intelecto e a faculdade sensitiva a partir dos elementos, i.e., de uma base puramente material:

O mesmo se dá no caso daqueles que derivam o intelecto (tòn noûn) e a faculdade sensitiva (tò aisthetikón) a partir dos elementos, pois as plantas parecem viver sem partilhar da locomoção (phorâs) ou da sensação (aisthéseós), e muitos dos animais não possuem pensamento (diánoian). (DA I, 410b 20-24) $)^{119}$.

Implícita na passagem está a premissa basilar a qual assere a presença dos mesmos elementos tanto nos seres dotados de intelecto e sensação quanto naqueles privados dessas faculdades. A consequência imediata da proveniência material destas seria sua ubiquidade, desmentida pela ausência de sensação e pensamento em certas espécies de seres vivos. Dessa forma, Aristóteles refuta, por contraposição, a tese segundo a qual o intelecto e a faculdade sensitiva reduzem-se aos elementos. Relevante para o propósito atual é o fato de a tentativa de redução operar no plano das partes (ou faculdades): locomoção, sensação e pensamento parecem ser tratados, na passagem, como processos, e não como funções anímicas hipostasiadas. O texto admitiria, a princípio, interpretá-los como decorrências das duas faculdades postas novamente no mesmo plano.

\footnotetext{
118 A despeito da intransponível subdeterminação (o termo implícito poderia, dado o contexto, ser, inclusive, "psychế"), tal leitura parece não acarretar nenhuma inconsistência.

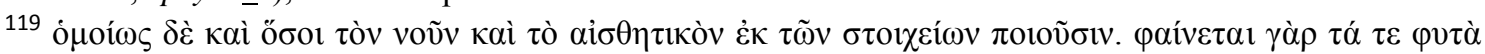

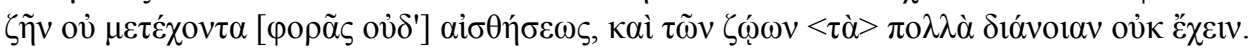


Logo em seguida, na sequência do trecho supracitado, ressurge o paralelo entre "noûs" e "tò aisthétikón", em uma passagem na qual é possível entrever a ideia, posteriormente desenvolvida no De Anima, de uma hierarquia de complexidade entre as almas dos diversos seres animados:

Se alguém supusesse ser o intelecto (tòn noûn) alguma parte da alma, e da mesma forma a faculdade sensitiva (tò aisthêtikón), não falaria universalmente sobre toda alma, nem mesmo sobre a totalidade de nenhuma. (DA I, 410b 25-28) ${ }^{120}$.

Nem toda alma, pois, tem como parte o intelecto ou a faculdade sensitiva, e nenhum tipo constitui-se exclusivamente a partir de uma dessas funções - através da primeira afirmação, inferem-se as diferenças existentes entre as almas dos seres vivos; pela segunda, entrevê-se a ideia de que a ascensão em complexidade é conservativa, i.e., a posse de uma função mais complexa depende da presença daquelas que na escala de complexidade lhe são inferiores.

Os termos "noûs" e "tò aisthêtikón" designam, mais uma vez, partes da alma, reforçando a tese segundo a qual tais expressões, no pensamento de Aristóteles, referem-se a entidades situadas no mesmo plano categorial. Sendo equivalentes, no contexto da investigação sobre a alma, as noções de parte e função, o texto do De Anima estabelece o adjetivo nominalizado "tò aisthêtikón" como a forma unívoca reservada para a denotação da sensação enquanto uma faculdade psíquica. Desse modo, outras formas hão de ser utilizadas para designar fenômenos anímicos como produtos ou processos atrelados a essa faculdade; no caso do termo "noûs", uma vez que o intelecto é concebido como uma parte da alma, situando-se, portanto, no mesmo plano ontológico da faculdade sensitiva, e dada sua concomitância relativamente a "tò aisthêtikón" nas passagens acima contempladas, é estabelecida sua univocidade na tarefa de designar a função anímica responsável pela assimilação dos objetos inteligíveis.

\subsection{Atividades psíquicas e verbos substantivados}

Além dos termos referentes a partes da alma e daqueles relativos a objetos assimiláveis por funções anímicas, a passagem em 402, 11-16 introduz a noção de

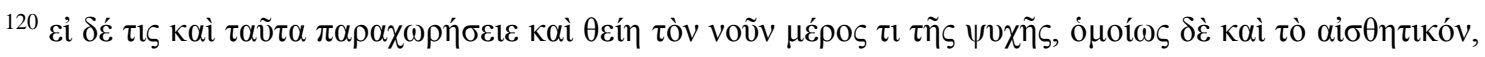

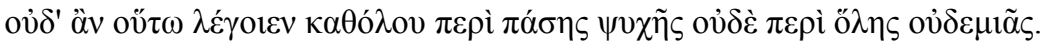


atividade, designada por verbos substantivados. Ao intelecto e à parte sensitiva correspondem tanto objetos (antikeímena) a serem assimilados quanto atividades (érga) específicas: no caso do primeiro, a operação correspondente é o inteligir (tò noeîn); em relação à segunda, tem-se o sentir (tò aisthánesthai). No contexto da investigação sobre a possibilidade de a alma mover-se, os fenômenos referidos por verbos substantivados são concebidos como movimentos (kinéseis):

Dizemos que a alma sofre, alegra-se, encoraja-se, teme e, além disso, que se enraivece, sente e pensa; todas essas coisas parecem ser movimentos. De onde alguém julgaria que ela se move, o que não é necessário: mesmo sendo o sofrer, o alegrar-se e o pensar movimentos, e cada um deles um mover-se, o mover-se ocorre pela alma, como o enraivecer-se ou o temer é o mover-se o coração de certo modo, e o pensar, isso ou outra coisa. (DA I, 408b, 2-9) ${ }^{121}$.

Essa passagem revela, pois, um importante aspecto ontológico das atividades anímicas: elas são, na teoria de Aristóteles sobre a alma, movimentos - mais especificamente, movimentos intrapsíquicos. Persistindo ao longo do texto a diferença entre parte e atividade, o trecho 408b, 2-9, ao explicitar um aspecto crucial da natureza dos entes referidos por verbos nominalizados, introduz a dicotomia entre faculdade e movimento no âmbito da investigação do De Anima. A noção de faculdade (dýnamis) está para as partes da alma assim como a de movimento (kínesis) está para suas operações.

Em seguida, no duplo intuito de chegar a uma expressão mais clara e de conciliar a imobilidade da alma com o fato de tais fenômenos, a despeito de anímicos, poderem ser concebidos como movimentos, afirma Aristóteles:

Dizer que a alma enraivece-se é como dizer que ela tece ou constrói: melhor é não dizer que a alma apieda-se, aprende ou pensa, mas que o ser humano o faz por meio da alma. E isso não como estando nela o movimento, mas como se ora fosse até ela, ora dela partisse; por exemplo: a sensação parte de certas coisas, enquanto a reminiscência parte da alma e direciona-se para os movimentos ou pontos nos órgãos sensoriais. (DA I, 408b, 13-18) $)^{122}$.

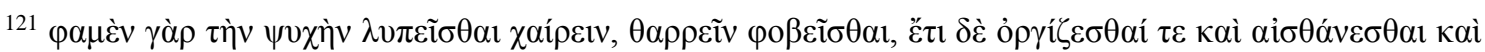

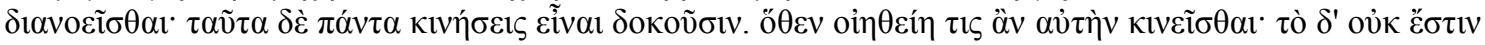

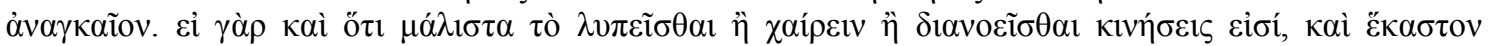

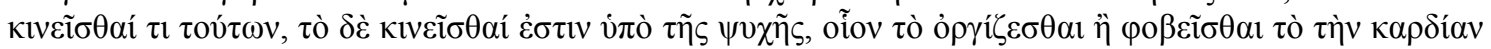

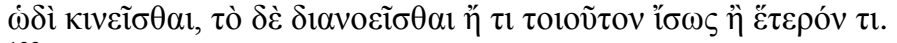

${ }^{122} \tau$

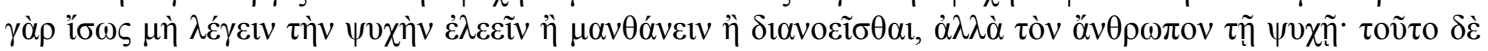


Aqui, o termo "aísthessis", utilizado no De Anima III para designar uma função psíquica, é empregado como significando um movimento - indica-se, inclusive, o sentido de tal movimento (das coisas externas para a alma, i.e., de fora para dentro). $\mathrm{O}$ fluxo do texto exige, então, a sinonímia entre a ocorrência de "aísthessis" em 408 b17 e "tò aisthánesthai", uma vez que Aristóteles lança mão do conceito de movimento para caracterizar a referência de ambos os termos - tal opção mostra-se mais parcimoniosa, pois não postula a existência de dois movimentos distintos ligados a uma mesma faculdade. Dessa forma, a sensação aparece no primeiro livro do De Anima não como uma faculdade psíquica, mas como uma atividade.

Além da passagem supracitada, há outro indício, em um trecho anterior, do vínculo possível entre palavras com o sufixo “-sis” e a ideia de movimento. Criticando a noção de alma encontrada no Timeu de Platão (DA I, 407a, 3 - 407b, 13) - alma como uma magnitude (mégethos), i.e., como uma entidade de natureza espacial -, escreve Aristóteles: "O movimento do intelecto (noû) é a intelecção (nóesis), e o do círculo, a revolução." (DA I, 407a, 20) ${ }^{123}$. Ora, se é apropriada a identificação entre aísthesis e tò aisthánesthai - pelo critério da parcimônia, a diferenciação dar-se-ia unicamente no plano linguístico, em virtude de não haver bases para se identificar duas espécies de movimentos ligados à faculdade sensitiva, uma denotada por "tò aisthánesthai", e a outra, por "aísthesis" -, também o é o tratamento de nóesis e tò noeîn como processos idênticos. Porém, independentemente do reconhecimento dessas equivalências, o primeiro livro do De Anima torna explícita a existência, no contexto específico da investigação sobre a alma, do vínculo entre o conceito de movimento intrapsíquico e substantivos com a terminação "-sis".

\subsection{Atividade e movimento}

Um pouco adiante, argumentando contra a visão daqueles que concebem a alma a partir do número e do movimento, observa Aristóteles:

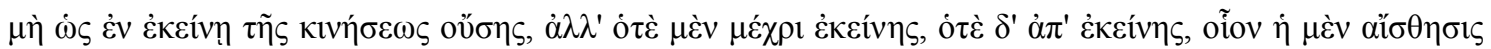

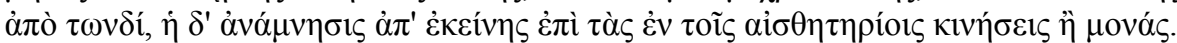

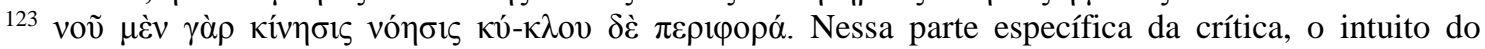
filósofo é atacar a visão segundo a qual o movimento do intelecto seria circular. Dada a analogia entre o movimento deste e o do círculo, a intelecção haveria de ser eterna como a revolução (DA I, 407a, 24). Na filosofia de Aristóteles, contudo, o pensamento e sua expressão verbal são ambos determinados: "as intelecções práticas têm limites (pois todas visam a um fim), e as teóricas são, como o discurso, limitadas." (DA I, 407a, 25). 
Não apenas é impossível que tal seja a definição de alma, mas também que seja dela um atributo. Isso torna-se claro ao se tentar, a partir dessa concepção, fornecer uma explicação das afecções e atividades da alma, como os raciocínios, sensações, prazeres, dores, e outras coisas como essas. (DA I, 409b, 14-17) ${ }^{124}$.

Se no trecho anteriormente citado a sensação é concebida como um movimento intrapsíquico, aqui ela é vinculada de maneira explícita à noção correlata de atividade. Na passagem supracitada, o mesmo termo sob o qual são englobadas as referências dos verbos substantivados em 402b, 11-16, abarca também a designação da palavra "aísthesis": a sensação, assim como o sentir, localiza-se no conjunto das atividades (érga) da alma, ao invés de constituir uma faculdade desta. Tal fato reforça a tese da identidade entre as designações de "tò aisthánesthai" e "aísthesis"125, pois ambas encontram-se simultaneamente englobadas sob dois conceitos fundamentais da investigação conduzida no De Anima, a bem dizer, os conceitos de atividade anímica e de movimento intrapsíquico. Além disso, é reforçada, por meio dessa concomitância, a tese mais geral de que tais noções revelam aspectos diversos de um único fenômeno; o mesmo argumento que estabelece a coextensão de "parte" e "faculdade" aplica-se, assim, mutatis mutandis, a "atividade" e "movimento" - a sensação e o sentir são ora descritos como "érga", ora como "kinéseis", não podendo essa variação, em virtude da especificidade do fenômeno sob escrutínio, ser fruto de mero lapso ou possuir um caráter acidental.

A possibilidade do paralelismo semântico entre expressões construídas a partir da nominalização de formas verbais infinitivas e seus correlatos sufixados em "-sis" reaparece de maneira mais sutil em uma passagem posterior do De Anima I. No contexto da questão relativa à estruturação mereológica da alma, indaga Aristóteles:

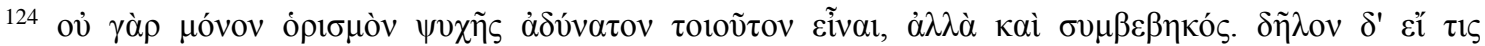

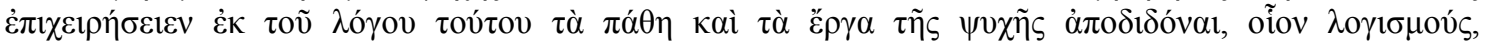

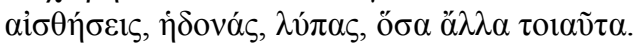

${ }^{125}$ Tal tese parece, à primeira vista, ser refutada pelo expresso nas Categorias. Tratando da categoria da relação, o filósofo afirma: "O estar deitado, o estar em pé e o estar sentado são posições (he anáklisis kaì he stásis kaì he kathédra théseis tinés), e a posição é relativa. Já o deitar-se (tò anakeîsthai), o levantar-se (hestánai) e o sentar-se (kathệsthai) não são posições, mas derivam seus nomes das posições mencionadas." (Cat, 6b, 11-14). Essa passagem expressa uma diferença nocional entre pares de termos cujo segundo elemento consiste precisamente em um verbo substantivado: a despeito da parônimia em relação a "anáklisis", "stásis" e "kathédra", respectivamente, "tò anakeîsthai", "tó hestánai" e "tò kathếsthai" não denotam posições, mas ações, enquadrando-se, ipso facto, em outra categoria ontológica. Levando-se em conta apenas a forma dos termos, a identidade nocional entre "aísthesis" e "tò aisthánesthai" não surge, dada a passagem citada, como óbvia. Todavia, "tò aisthánesthai", diferentemente dos termos listados em Cat. 6b11, não designa uma ação, mas uma afecção; sendo assim, essa passagem não exclui a possibilidade de "aísthesis" e "tò aisthánesthai" pertencerem à mesma categoria, visto que o resultado do sentir não se trata, seguramente, de uma posição.
} 
Visto que o conhecer, o sentir e o opinar são da alma, além do desejar, do querer e, de modo geral, dos apetites [...], inteligimos e sentimos com toda a alma, ou fazemos cada coisa com partes diferentes? E quanto ao viver? Está ele em uma dessas partes, em várias ou em todas? (DA I, 411b27- 411b4) $)^{126}$.

Nesse trecho, o plural de "órexis" é elencado juntamente com expressões cujas referências são atividades ou movimentos intrapsíquicos. Sob o aspecto puramente filosófico-semântico, seu lugar na enumeração representa uma quebra de paralelismo, uma vez que sua ocorrência se dá após uma gama de verbos nominalizados. Sob outro viés, contudo, o lugar de "oréxeis" na passagem parece indicar sua referência como estando situada no mesmo plano ontológico do conhecer, do sentir e do opinar, i.e., no plano das atividades da alma. Assim sendo, expressa-se novamente, por meio de outro caso particular, a possibilidade formal, no contexto da investigação de Aristóteles sobre o princípio da vida e suas operações, do paralelismo semântico entre verbos nominalizados e substantivos com terminação em "-sis", reforçando-se, desse modo, o argumento baseado na ocorrência de "aístheseis" em 409b 15, o qual estabelece a identidade entre a designação de "aísthesis" e a referência de "tò aisthánesthai", ou seja, entre sensação e sentir.

Evidentemente, as duas últimas passagens citadas possuem certas diferenças: 409b14-17 é direcionada às concepções pitagóricas relativas à alma, enquanto 411b27411 b4 constitui uma série de indagações sobre a melhor maneira de articular os conceitos de parte e atividade psíquicas. Além disso, enquanto em uma ocorre a palavra "aísthéseis" juntamente com outras não originadas de nominalizações ("logismoús", "hedonás", "lýpas"), na outra há a ocorrência de "oréxeis" ao lado de verbos substantivados. Tais diferenças, todavia, de modo algum ameaçam a solidez do argumento apresentado, cuja conclusão estabelece a sinonímia entre estes e os termos correlatos com terminação em "-sis". O fato de na passagem supracitada os termos elencados serem majoritariamente verbos nominalizados e não, como em 409b14-17, substantivos primitivos, não afeta em absoluto as bases do argumento, pois, como já foi mostrado, as noções de atividade e movimento permitem efetuar o vínculo semântico

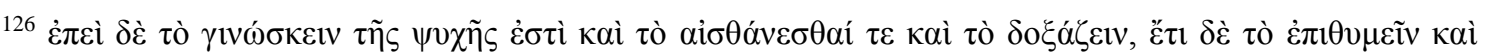

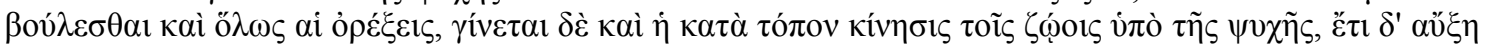

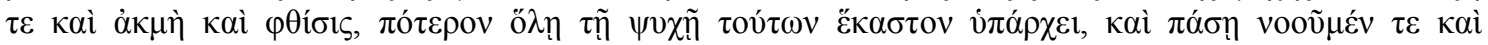

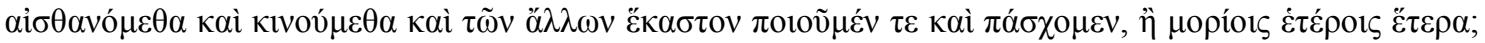

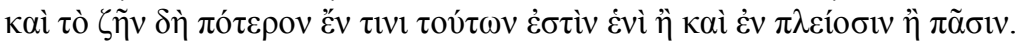


entre ambos os tipos de construção. Tampouco a diversidade de intenção justifica a dúvida quanto à possibilidade de se usar ambas as passagens no intuito de fundamentar um mesmo argumento, pois padrões linguístico-conceituais ressurgem nos mais variados contextos, seja no âmbito da refutação de uma teoria rival (409b14-17), seja no de uma construção retórica cuja finalidade é ressaltar os problemas a serem ainda resolvidos (411b27-411b4) - ademais, a diferença de intenção certamente deixa-se ofuscar pelo fato de ambas as passagens pertencerem à fração aporética do tratado.

\subsection{Formas no plural}

A despeito das diferenças consideradas, as duas passagens trazem fenômenos psíquicos referidos por termos flexionados no plural: em 409b14-17, dentre outras expressões flexionadas no mesmo número, tem-se "aisthéseis", construção de natureza idêntica à de "oréxeis", encontrada no trecho supracitado. Tal fato, trivial sob um primeiro olhar, revela-se, não obstante a aparência de mera peça de diletantismo filológico, a chave para tornar inteligível dentro da estrutura do De Anima a ocorrência de "phantasíai" em 428a12: "As phantasíai, em sua maioria, surgem (gínontai) como falsas". As passagens destacadas do De Anima I revelam a pluralização como possibilidade exclusiva dos termos cujas referências são movimentos intrapsíquicos: em momento algum ela incide sobre expressões utilizadas para designar partes ou funções. Desse modo, se expressa no plural, trata-se de uma atividade.

Além do vínculo indireto estabelecido pela pluralização de "aísthesis", "órexis" e "phantasía", estabelecem-se, ainda no De Anima II, relações diretas entre os três fenômenos em questão. Ao falar do caso dos insetos segmentados, Aristóteles estabelece relações de acarretamento entre a sensação e diversos outros movimentos intrapsíquicos:

Cada uma das partes [dos indivíduos segmentados] possui sensação e movimento espacial. Se possui sensação, possui também e apetite; onde há sensação, há também dor e prazer, e onde estas estão presentes, é necessário haver também desejo. (DA II, 413b, 21-24) ${ }^{127}$.

De maneira explícita, pois, colocam-se no mesmo plano ontológico a sensação, o apetite e a phantasía. A dor e o prazer já haviam sido postos no mesmo patamar da

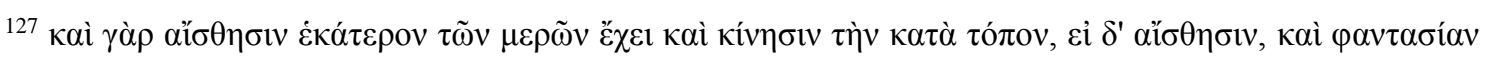

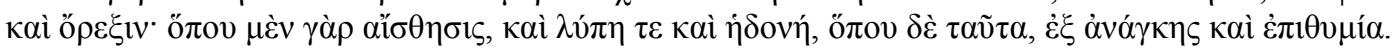


sensação, ao serem concebidos como afecções ou atividades (DA I, 409b, 14-17). A phantasía, assim, antes de constituir uma função, surge no De Anima I como atividade e movimento, e o uso de seu conceito enquanto tal repete-se no terceiro livro do tratado, jamais caracterizando-se pela opção de univocidade em favor da ideia de função ou parte imaginativa.

$\mathrm{Na}$ verdade, o primeiro livro do De Anima não traz nenhuma ocorrência da phantasía enquanto faculdade anímica. A primeira passagem na qual se utiliza o termo, a qual se insere no contexto das considerações metodológicas expostas no começo da obra, certamente exemplifica um significado genérico de aparência, em vez do sentido específico de função psíquica:

\begin{abstract}
Não apenas o saber o que é é útil para compreender as causas dos atributos das substâncias, como nos estudos matemáticos é útil o conhecimento relativo ao que é o reto e o curvo ou o que é a linha e a figura plana para apreender a quantos ângulos retos equivalem os ângulos do triângulo, mas também os atributos muito acrescentam ao conhecimento do que é: pois quando temos condições de fornecer, de acordo com a phantasía, todos ou a maioria dos atributos, então estamos mais bem qualificados para falar sobre a substância; pois de toda demonstração é o que é princípio. (DA I, 402b, 17-26) ${ }^{128}$.
\end{abstract}

De acordo com a phantasía, pois, são apresentados os atributos do objeto sob investigação. Faz-se mister aqui deflacionar a interpretação da ocorrência do termo "phantasía", evitando-se tratá-la como referindo uma função anímica cuja especialidade consiste em fornecer à mente o conhecimento das qualidades e propriedades dos objetos, pois em passagem alguma do tratado a phantasía é assim caracterizada. É razoável supor que o sentido da expressão no trecho supracitado limita-se à ideia de mera aparência, principalmente à de aparência sensível - da substância enquanto princípio metafísico manifestam-se aos sentidos apenas os atributos, e a partir dessas manifestações, como o próprio trecho revela, qualifica-se positivamente o discurso acerca do substrato.

Ainda dentro do contexto das considerações metodológicas, afirma o filósofo: “O princípio da investigação é expor as coisas que mais parecem lhe pertencer [i.e., à

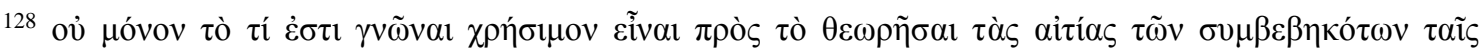

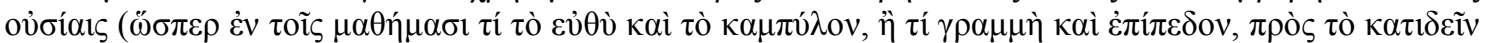

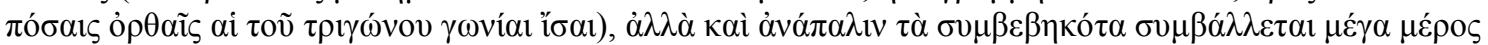

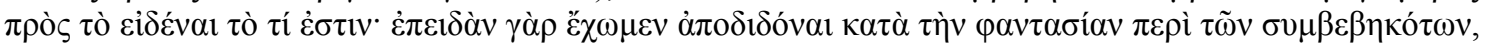

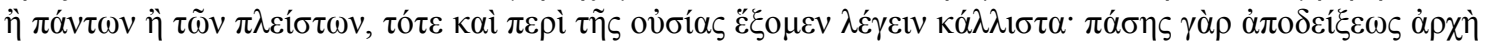

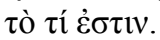


alma] segundo a natureza. $\mathrm{O}$ animado parece diferir do inanimado em duas coisas: $\mathrm{o}$ movimento e o sentir." (DA I, 403b, 25-26) ${ }^{129}$.

Tais considerações acerca do método apropriado para se chegar à definição de alma condizem com a distinção, traçada em outras obras, entre o que é mais cognoscível para o indivíduo cognoscente e o que é mais cognoscível em $\mathrm{si}^{130}$. Sendo o critério a distância do objeto conhecido em relação à sensibilidade - o mais cognoscível em si é o mais afastado da sensação e, ipso facto, o menos cognoscível para o indivíduo -, e visto que a aquisição do conhecimento inicia-se com as coisas menos cognoscíveis por natureza (i.e, as mais próximas da sensação) ${ }^{131}$, à apreensão da essência, aspecto da coisa concebido por Aristóteles como o que de mais absolutamente cognoscível há, antecede o fornecimento dos atributos ${ }^{132}$. Por incorporar de maneira explícita um

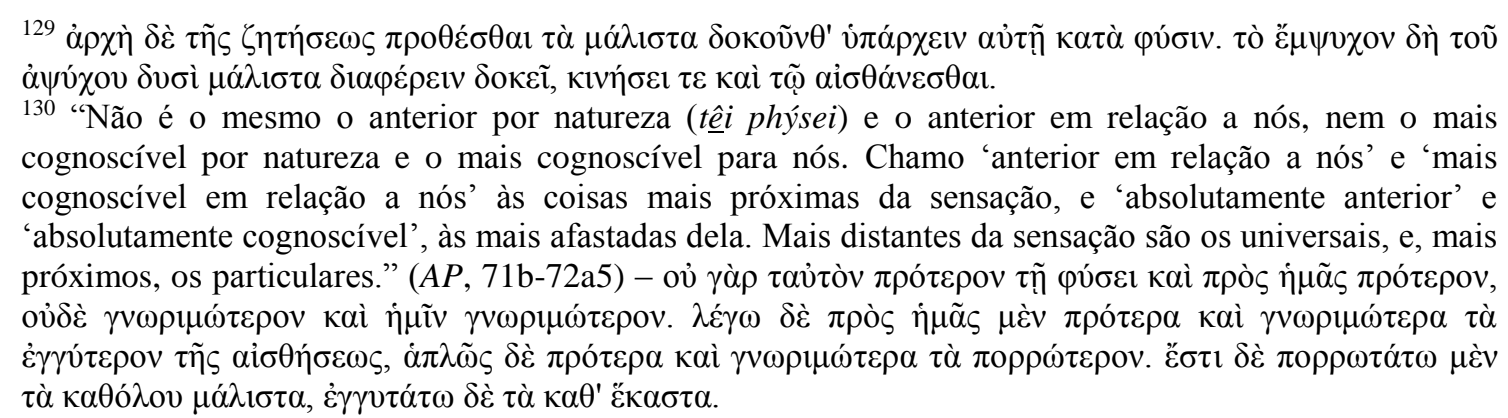

${ }^{131}$ Na Metafísica (VII, 1029b, 4-5), lê-se: "A aprendizagem se realiza para todos através da passagem pelas coisas menos cognoscíveis por natureza em direção às mais cognoscíveis." No De Anima, pode-se reconhecer a sustentação da mesma tese, ainda que sob uma roupagem diversa: "A partir das coisas não

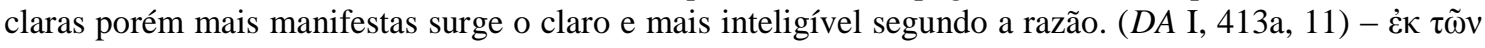

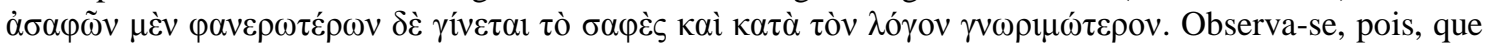
enquanto na Metafísica fala-se de uma maior cognoscibilidade por natureza (phýsei), no De Anima a expressão "mais cognoscível" vem modificada por "segundo a razão" (katà tòn lógon). Tal variação, contudo, não aponta para um afastamento teórico fundamental, uma vez que o contraste é o mesmo em ambos os trechos - nas duas passagens o filósofo trata dos graus de cognoscibilidade. No De Anima, contudo, observa-se uma interessante variação vocabular: "claro" (saphés) e "mais manifesto" (phaneróteron), apesar de terem, à primeira vista, sentidos equivalentes, são colocados em oposição, uma vez que o mais inteligível (gnórimóteron) pode ser qualificado como claro, mas não como mais manifesto. As coisas mais manifestas, por sua vez, são justamente as não claras (asaphôn $)$. Cabe ressaltar aqui o parentesco etimológico entre o adjetivo "phanerós", empregado em 413,11, na forma aumentativa, e o substantivo "phantasía", bem como a semelhança temática entre esse trecho e 402b, 17-26, no qual se lê a expressão "katà tẹn phantasían". A partir dos Segundos Analíticos e da Metafísica é possível estabelecer as conexões semânticas entre "mais cognoscível em relação a nós", "anterior em relação a nós", "coisas mais próximas da sensação", "coisas menos cognoscíveis por natureza", "coisas não claras, "coisas mais manifestas", "de acordo com a phantasía", "atributos" e "particulares". Poder-se-ia pensar que o fato de as referências dessas duas últimas expressões enquadrarem-se em categorias ontológicas distintas desmantelaria a tentativa de estabelecer um vínculo de significado entre as demais; todavia, basta pensar na diferenciação de ambas relativamente a um aspecto comum, a bem dizer, à essência, caracterizada por expressões contrárias, visto ser ela o aspecto inteligível por excelência. Assim, aquilo que se apresenta de acordo com a phantasía, sendo, ipso facto, mais manifesto, não é a essência, cuja cognoscibilidade se dá de acordo com a razão (katà tòn lógon) - e não de acordo com a phantasía -, mas as coisas mais próximas da sensação. O contato com o manifesto - i.e., com o aparente - constitui a primeira etapa de um processo que culmina na apreensão do absolutamente cognoscível.

${ }^{132}$ Deslauriers $(2007,195)$ afirma: Se pensarmos que a distinção nos Segundos Analíticos e aquela na Metafísica são a mesma distinção, o que é mais cognoscível de maneira absoluta ou por natureza é a 
método de investigação erigido sobre sólidas bases ontológicas e gnoseológicas alhures lançadas, o De Anima certamente figura, com sua riqueza de pressupostos e aplicações de teses fundamentais ao estudo da alma, entre os trabalhos ulteriores do Corpus Aristotelicum.

Em momento algum, pois, a phantasía é concebida como a faculdade especializada em fornecer os aspectos menos cognoscíveis das coisas. O critério para a determinação do grau de cognoscibilidade dá-se relativamente às sensações, devendo a ocorrência do termo "phantasía" em 402 b25 ser interpretada a partir da noção de mera aparência, uma vez que o movimento, por exemplo, atributo previamente considerado por Aristóteles na busca pela definição da alma em virtude de sua posse, por parte desta, conformar-se às aparências, constitui um objeto sensível. O tipo de phantasía mencionado em 402 b25 é consequência, portanto, da sensação, não sendo englobado pelo conceito de faculdade anímica. A ideia subjacente à ocorrência do termo na passagem remete ao modo como certos aspectos das coisas são apreendidos pelo indivíduo cognoscente, i.e., à acessibilidade imediata a tais aspectos - em contraste com a maneira pela qual são assimilados os aspectos mais afastados da sensação. Desses atributos inteligíveis não há, no contexto do início da investigação científica, aparência.

\subsection{Relações entre "phantasía" e verbos substantivados}

As duas ocorrências seguintes surgem no contexto das considerações preliminares a respeito da separabilidade da alma relativamente ao corpo que a contém. Aristóteles, logo antes de estabelecer como eixo do problema a questão mais básica da possibilidade de a alma operar ou ser afetada sem concomitantes operações ou afecções corpóreas ${ }^{133}$, assim afirma: "Parece que o inteligir constitui uma exceção: se também ele é alguma phantasía ou não ocorre sem phantasía, nem mesmo ele poderia existir sem corpo." (DA I, 403a, 8-10) ${ }^{134}$.

essência da coisa a ser definida e a causa primeira, i.e., uma causa que é mais universal e menos próxima da sensação."

133 "Se há alguma das atividades ou afecções (pathemátonn) que lhe seja própria, ela é capaz de existir separada do corpo; mas se não houver nada que lhe seja próprio, ela não é separável.” (DA I, 403a, 1112).

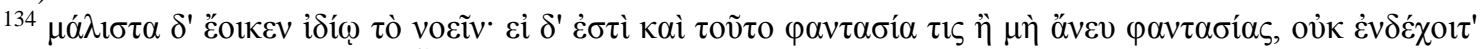

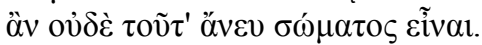


Porquanto as distinções expressas em 402b11-16 colocam o inteligir (tò noeîn) no plano das atividades (érga) da alma, as duas ocorrências de "phantasía" na passagem supracitada hão de ser, sob pena de desmantelar o paralelismo necessário, interpretadas como se referindo não a uma parte ou função anímica, mas a uma atividade $^{135}$. O inteligir não é função, mas movimento e atividade - não é algo que se encontra na alma enquanto uma sua parte determinada e estruturante, mas um fenômeno decorrente do intelecto, i.e., algo cuja ocorrência se dá em virtude de uma faculdade anímica, desta dependendo sob o ponto de vista das relações causais. O elemento hipostasiado como parte ou, ainda mais radicalmente, como substância (ousía) não é o movimento do inteligir em sua dinâmica processual, mas o intelecto, estático em sua suposta impassibilidade ${ }^{136}$.

Ao considerar a possibilidade de o inteligir ser um tipo de phantasía, Aristóteles coloca esta no mesmo plano daquele, pois uma atividade só pode ser especificada a partir de outra atividade - a hipótese de um erro categorial deve ser rejeitada ab initio, dada a univocidade das expressões construídas a partir da nominalização de adjetivos. A colocação de ambos no mesmo plano ocorre também a partir da segunda possibilidade considerada, qual seja, a da phantasía como condição necessária para a efetuação do inteligir: para haver deste a ocorrência, faz-se mister uma atividade concomitante, ou seja, deve existir o concurso de algo situado no mesmo plano categorial, ainda que proveniente de uma função anímica diversa. Não obstante ser a presença desta imprescindível - dada a rígida organização ascendente-conservativa da posse das faculdades da alma -, trata-se, na passagem, da ocorrência de um movimento, e suas pré-condições devem, ao menos nesse contexto específico, ser entendidas enquanto tais: importa ali, primeiramente, a atividade da função.

No primeiro livro do De Anima, portanto, a phantasía não é em momento algum alçada à categoria de faculdade anímica, mas surge, se não como mera aparência, no máximo como movimento psíquico, sendo disposta, assim, no plano das atividades da alma. Tomando-se por satisfatória a análise da ocorrência do termo "phantasía" no contexto das breves considerações gnoseológicas em 402b, 17-26, procede-se agora à

\footnotetext{
${ }^{135} \mathrm{Em}$ 427b, 28, já na abordagem detalhada do terceiro livro do tratado, Aristóteles novamente relaciona a phantasía a atividades psíquicas: "Acerca do inteligir, visto diferir ele do sentir (tô̂ aisthánesthai), parece ser ele, por um lado, phantasía, mas, por outro, suposição." Há recorrência, portanto, do uso do termo "phantasía" ao lado de expressões designadoras de movimentos intrapsíquicos.

136 "O intelecto parece surgir como uma substância (ousía tis oûsa) e ser imperecível." (DA I, 408b, 19) -

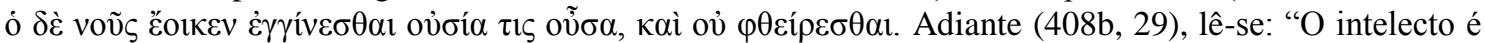

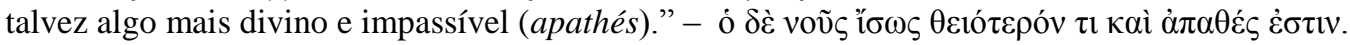


tentativa de articular conclusivamente a noção aristotélica de phantasía dentro dos esquemas dicotômicos localizados no corpo do texto - parte-atividade e funçãomovimento.

\subsection{Contra a tendência majoritária}

O fato de a phantasía surgir na primeira parte do De Anima como um movimento intrapsíquico e uma atividade representa algum desvio ou inconsistência apenas se estiverem sob consideração o trecho 428a2, no qual ela é concebida a princípio como uma faculdade ou disposição, e a tendência majoritária entre comentadores hodiernos, caracterizada pela ênfase no sentido de "phantasía" enquanto função anímica ${ }^{137}$. Se, porém, a atenção for direcionada para a letra do estudo minucioso localizado na terceira parte do tratado, notar-se-á não uma tentativa explícita de renovação completa do status categorial da phantasía, mas, ao invés, a manutenção e o consequente desenvolvimento daquilo que anteriormente era apenas indicado. Ao final da exposição detalhada, Aristóteles, considerando esta satisfatória - "Se nada além da phantasía possui as coisas aqui descritas [...]" (DA III, 429a, 1) $)^{138}-$, define a phantasía como um movimento causado pela sensação em ato (429a, 2). Essa conclusão é fundamentada por uma tese geral acerca do movimento das coisas, a qual estabelece a possibilidade de um objeto, uma vez posto em movimento, mover outro ${ }^{139}$, bem como pela tese específica acerca da sensação em ato enquanto origem de um segundo movimento (428a, 13-14). Também atuam como premissas no argumento duas afirmações a respeito do que a phantasía parece ser (dokê̂ ê̂nai), a primeira delas

137 "É Aristóteles quem forneceu a primeira descrição analítica extensa da imaginação como uma faculdade da alma distinta." (Schofield, 1992 250); "phantasía enquanto a faculdade em virtude da qual qualquer phainómenon é experimentado." (ibid., 258) "phantasía concebida como uma faculdade voltada para experiências não paradigmáticas." (ibid., 261) "É evidente que Aristóteles pensava que uma única faculdade de imaginação estava envolvida nos vários fenômenos que ele trata como casos de phantasía." (ibid., 273, n. 52) "Além de aísthesis e phantasía constituírem operações da mesma faculdade da alma (a faculdade perceptiva), são diferentes entre si." (DÍAZ, 2009, 171) "A faculdade sensitiva abarca um conjunto de funções especializadas: percepção dos sensíveis próprios, comuns e acidentais, apercepção e phantasía, a qual, por sua vez, intervém na memória, no sonho e em diversas funções relacionadas com o desejo e a ação." (ibid., 175). "Essa situação singular implica que a phantasía seja frequentemente considerada uma faculdade intermediária entre a sensação e o pensamento." (LABARRIÈRE, 19, 2004). "A phantasía é uma faculdade da alma, a imaginativa (phantastikón), localizada entre a sensação (aísthesis) e o pensamento (diánoia). (PAPACHRISTOU, 44, 2013). "Limitar-me-ei a um retrato de duas funções principais da phantasía na psicologia de Aristóteles: seu papel na síntese e retenção de percepções sensoriais, e seu papel em aplicar pensamento a objetos da percepção sensorial." (FREDE, 1992, 283). Lycos $(1964,496)$ opta por traduzir "phantasía" por "faculdade de apresentação".

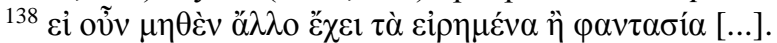

139 "É possível que, tendo sido determinada coisa movida, outra coisa seja movida por ela." (DA III, 428b, $11)$. 
versando sobre o fato de esta consistir, aparentemente, em um movimento, e a segunda, sobre o fato de apenas seres sensitivos possuírem-na (428a, 12).

Após definir a phantasía como um movimento causado pela atividade da sensação e esboçar uma etimologia a partir da palavra "pháos" - relacionando-a novamente, dessa forma, à sensibilidade, uma vez que a luz é condição necessária para o sentido principal, i.e., para a visão (429a, 3-4) -, Aristóteles finaliza a exposição atribuindo à durabilidade das phantasíai e à sua semelhança relativamente às sensações a causa de os animais agirem com frequência de acordo com elas:

Porque permanecem e assemelham-se às sensações, os animais fazem muitas coisas de acordo com elas; uns, como as feras, por não possuírem intelecto, e outros, como os seres humanos, por seu intelecto às vezes obscurecer-se por conta de afecção, doenças ou sono. (DA III, 429a, 5-9).

Nessa passagem, utiliza-se o plural tanto para "aísthesis" quanto para "phantasía", o que indica, como estabelecido acima, o sentido de atividade ou movimento intrapsíquico ${ }^{140}$. "Taîs aisthésesi" e "kat'autás" remetem não à unidade de uma função anímica diferenciada, mas a uma pluralidade de fenômenos intrapsíquicos, a uma profusão de movimentos sensíveis de primeira e segunda ordem aos quais certos entes reagem. Do início ao fim da abordagem específica do De Anima III.3, tirante 428a1, o vocabulário utilizado por Aristóteles para descrever os mecanismos da phantasía adequa-se ao léxico próprio das atividades/movimentos da alma.

\section{NOTAS SOBRE A DEFINIÇÃO DE PHANTASÍA}

Aristóteles encerra o estudo detalhado da noção de phantasía com as seguintes palavras: "A respeito do que é (tí esti) a phantasía e de sua causa (dià tî), basta o que foi dito." (429a, 09). A partir desse enunciado final, vislumbra-se a intenção do filósofo em tomar os resultados de seu estudo como apropriados para uma caracterização rigorosa da phantasía. No início do livro II dos Segundos Analíticos, lê-se: “O número das coisas investigadas é igual ao das coisas que conhecemos. Investigamos quatro coisas: o fato (tò hóti), a causa (tò dióti), a existência (ei ésti) e a essência (tí estin)." (AP II, 89b, 2324).

\footnotetext{
${ }^{140}$ Uma exceção seria o uso de "aisthéseis" no intuito de referir-se às modalidades sensórias, o que indicaria o sentido de faculdade anímica. No contexto da passagem sob exame, todavia, trata-se obviamente de "aisthéseis" enquanto referente a movimentos intrapsíquicos.
} 
De acordo com Aristóteles, pois, o conhecimento é a posse da resposta referente a uma dessas quatro coisas. Na última frase do De Anima III.3, observam-se as expressões " $t i ́$ esti" e "dià $t \hat{\imath}$ ", as quais remetem, respectivamente, às investigações acerca da essência e da causa de determinado fenômeno. Ao considerar suficiente o estudo levado a cabo nessa parte da obra para expor a essência e a causa da phantasía, o filósofo crê haver sua investigação desembocado não em mera opinião provisória, mas em conhecimento efetivo. A definição apresentada revela, assim, a verdade acerca da phantasía $^{141}$, uma vez que o conhecimento jamais relaciona-se com o falso, apenas com o verdadeiro (DA III, 428a, 16) ${ }^{142}$.

O resultado da investigação detalhada sobre o conceito de phantasía adequa-se formalmente às diretrizes apresentadas na teoria aristotélica da ciência para a construção de enunciados definitórios. Segundo Aristóteles, essência e causa equivalem, i.e., há a identidade entre "tí estin" e "tò dióti" - determinada a essência de um fenômeno, determina-se também a sua causa:

Em todos esses casos [i.e., no caso do eclipse, da igualdade, da desigualdade, da interposição e da não interposição] é evidente que a essência e a causa são o mesmo. O que é um eclipse? É a privação de luz na Lua por conta da obstrução pela Terra. Por que ocorre um eclipse, ou por que a Lua é eclipsada? Por conta de a luz do sol falhar, tendo a Terra obstruído a Lua. O que é uma harmonia? Uma razão numérica do tom agudo e do tom grave. Porque o agudo harmoniza-se com o grave? Por conta de o agudo e o grave possuírem uma razão numérica. (AP II, 90a, 14-21) ${ }^{143}$.

Dessa forma, então, ao fornecer-se uma explicação a respeito do que é determinado evento, evidenciam-se ao mesmo tempo os elementos situados na rede causal responsável por sua ocorrência ${ }^{144}$. Formalmente, a resposta à pergunta relativa à essência é construída de modo a abarcar uma expressão verbal da causa, e vice-versa: o

\footnotetext{
${ }^{141}$ Tal análise estabelece como injustificado o ceticismo de Robert B. Todd (n. 56, 1981) acerca do caráter definitivo da definição de phantasía a partir dos conceitos de movimento e sensação: "Em lugar algum Aristóteles diz que a descrição de phantasía como um movimento derivado da sensação em ato é uma definição mais apropriada que 'aquilo por meio do qual um phántasma ocorre', em 428a, onde a sensação sequer é mencionada." O trecho do De Anima 429a, 9 - em conjunto com as considerações elementares a respeito do saber científico nos Segundos Analíticos - basta para atestar a intenção de Aristóteles em fornecer, por meio do enunciado expresso em 429a, 2, uma definição genuína do fenômeno da phantasía.

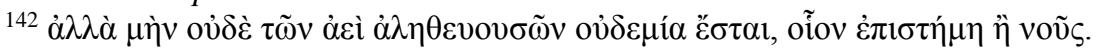

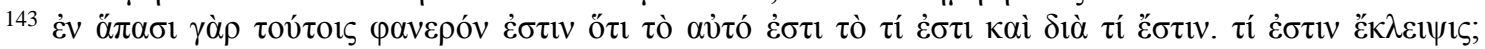

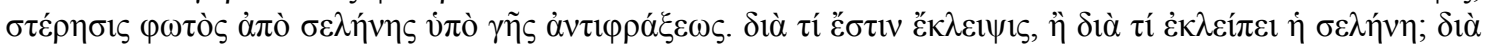

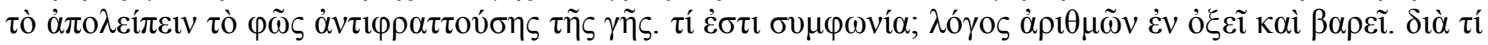

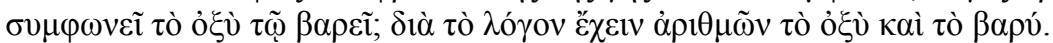

144 "O que um eclipse é é em parte como um eclipse é produzido." (DESLAURIERS, 2007, 91).
} 
eclipse, assim, é a privação de luz na Lua por conta da obstrução pela Terra, e a causa da harmonia é a posse de uma razão numérica por parte dos tons grave e agudo. Certos termos são mantidos ao transitar-se de uma resposta para outra: "luz" e "Terra", por exemplo, são utilizados nos enunciados tanto da causa quanto da essência do eclipse, assim como "razão numérica", "agudo" e "grave" no caso da harmonia; havendo variação - substantivo no enunciado da essência, verbo no da causa -, preserva-se o vínculo semântico entre as expressões alternantes ("privação da luz" e "falhar a luz", "razão numérica" e "possuir razão numérica").

\subsection{Comentando o DA III.3 à luz dos Segundos Analíticos}

Formalmente, a definição de phantasía apresentada ao final do De Anima III.3 não difere, em absoluto, dos exemplos utilizados nos Segundos Analíticos para ilustrar a equivalência entre a fórmula verbal da essência e o enunciado relativo à causa. $\mathrm{Na}$ formulação das noções referentes a cada um dos fenômenos, observa-se, em primeiro lugar, o uso de um conceito mais abrangente sob o qual é possível subsumir o definiendum: o eclipse, por exemplo, é definido a partir da privação de luz (stérésis photós), a harmonia, a partir da razão numérica (lógos arithmôn), e a phantasía, a partir do movimento (kínesis). Privação de luz, razão numérica e movimento consistem, assim, em gêneros dos quais o eclipse, a harmonia e a phantasía são, respectivamente, as espécies. Justamente por aqueles não se confundirem com os definienda - dada a maior extensão de seus conceitos -, as definições ora sob exame não incorrem no vício de circularidade. A referência ao gênero constitui, desse modo, a primeira semelhança formal entre o enunciado definitório da phantasía e os exemplos extraídos dos Segundos Analíticos.

Nas três definições, além da menção aos gêneros sob os quais os eventos subsomem-se, observa-se a referência às suas diferenças específicas: desse modo, o eclipse não é apenas uma privação de luz, mas uma privação de luz causada pela obstrução da terra, e a harmonia, uma razão numérica dos tons agudo e grave - não uma razão numérica simpliciter. De acordo com a mesma estrutura formal, especifica-se a phantasía a partir da sensação em ato, visto não ser o movimento suficiente para diferenciá-la.

Outra semelhança estrutural entre os componentes da tríade de definições é a possibilidade de converter o enunciado do ser do fenômeno em uma expressão dos mecanismos de sua origem, visto que o conceito apresentado para a veiculação da 
essência contém em si a informação referente à causa. Na definição de eclipse, por exemplo, lê-se a expressão "pela obstrução da terra" (hypò gệs antiphráxeós), a qual transmite, dado o conteúdo semântico da preposição "hypó", a ideia de causalidade. A despeito de não se encontrar, no De Anima, o enunciado definitório com ênfase na causa da phantasía, é possível, sem grandes saltos interpretativos, adequar o ato de conversão à expressão do ser do fenômeno lá investigado, pois também nesta informa-se o mecanismo de sua origem: a phantasía é um movimento causado pela sensação em ato (hypò tệs aisthéseos tê̂s kat'enérgein gignoménes). A construção do enunciado relativo ao ser da phantasía - o qual soluciona o problema acerca da essência desse fenômeno segue, assim, o mesmo padrão formal observado na definição de eclipse, podendo, ipso facto, converter-se em um enunciado da causa: se a formulação "movimento causado pela sensação em ato" responde ao questionamento relativo à essência (tí esti) do fenômeno, a partir dela pode-se derivar, a fim de responder à pergunta direcionada ao porquê (dià tí estin) da phantasía, a seguinte construção: "porque a sensação em ato produz um movimento". Tal resposta condiz não somente com o princípio aristotélico da equivalência entre enunciados quiditativos e causais, mas também com as premissas expostas em 428b, 11-14 no intuito de explicar a phantasía a partir do fato de a sensação poder ela mesma engendrar um movimento.

\subsection{O problema da phantasía como faculdade}

Tendo-se em vista, pois, a estrutura formal dos enunciados definitórios, a definição de phantasía apresentada nas linhas finais do De Anima III.3 não consiste em um mero recurso provisório a ser ulteriormente substituído conforme diferentes contextos argumentativos, mas em uma expressão genuína referente à essência daquele fenômeno ${ }^{145}$. Sendo assim, como há de se interpretar a descrição da phantasía enquanto "aquilo de acordo com o qual dizemos que um phántasma nos ocorre" (kath'hèn légomen phántasmá ti hemîn gígnesthai)? Essa descrição, além de ser a primeira encontrada no De Anima III.3 e explicar a ênfase dada, no contexto da literatura secundária sobre o tema, ao aspecto funcional da phantasía, mostra-se, sem restrições, adequada ao definiendum. Todavia, nela não se fazem presentes as noções fundamentais

\footnotetext{
${ }^{145}$ A descoberta de tal expressão é, precisamente, o objetivo do De Anima III.3, pois apenas em posse da

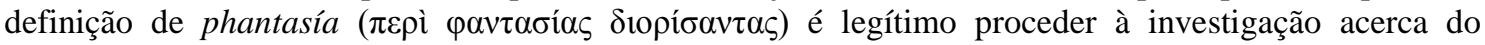
intelecto. (DA III, 427b, 30).
} 
de movimento e sensação. Haveria Aristóteles a substituído pelo definiens apresentado ao final do capítulo, o qual se baseia na mencionada díade de conceitos indispensáveis, e, consequentemente, abandonado a opinião de que a phantasía pode ser compreendida a partir da produção de imagens? Uma resposta afirmativa a esse questionamento teria como consequência uma revisão do significado da originalidade comumente atribuída à obra psicológica do filósofo no que concerne ao tema da phantasía. Em particular, impor-se-ia uma leitura segundo a qual a abordagem aristotélica não constituiria uma ruptura com a tradição precedente, dada a permanência da phantasía no âmbito das afecções: Aristóteles haveria apenas considerado por um breve instante a possibilidade de alçá-la ao patamar das funções anímicas; sua opção final, contudo, haver-se-ia resumido na definição apresentada em 429a, 2, a qual representa sua permanência na categoria de afecção. Entretanto, se desconsiderar tal definição não é viável, tampouco o é supor inexistente o caráter inovador da abordagem aristotélica: ao lançar mão do termo "tò phantastikón" - o qual denota, univocamente, uma faculdade anímica - e estabelecer a diferenciação possível entre phantasía e phántasma, Aristóteles provoca uma clara ruptura com a tradição precedente, cujo entendimento acerca da phantasía limitava-se às noções de afecção e aparência. Mister se faz, portanto, uma interpretação que preserve a inteligibilidade da coexistência de ambos os modos de definir a phantasía: há de se conciliar, respeitando-se a evidência textual, as noções de phantasía enquanto um movimento causado pela sensação em ato e enquanto algo responsável pela geração de imagens intrapsíquicas.

\subsection{Os tipos de definição}

A coexistência de definições diversas para a phantasía não torna, de maneira alguma, a abordagem aristotélica inconsistente. Nos Segundos Analíticos, o filósofo já previa a possibilidade de haver mais de um enunciado definitório para um mesmo fenômeno, uma vez que existem três tipos de definição: nominal (semântica), real (quiditativa) e demonstrativa (causal).

A definição nominal é, de acordo com Aristóteles, um "enunciado do que significa o nome ou outra expressão nominal" ( $A P$ II, 93b, 30) ${ }^{146}$. Tal enunciado permite efetuar o vínculo entre o nome e o fato (GUTHRIE, 1981, 176; ACKRILL, 1981, 369), não consistindo, assim, em uma relação entre palavras, mas entre uma

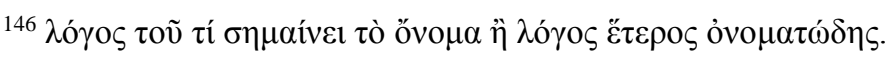


palavra e um estado de coisas efetivo. Dito de outro modo, não se trata de identificar a sinonímia entre expressões linguísticas diversas, mas de estabelecer a conexão entre a linguagem e o mundo por intermédio da capacidade denotativa dos termos singulares nesse contexto, o verbo "semaíno" pode ser adequadamente traduzido por "referir" ou “denotar". Como exemplo de definição nominal, Aristóteles fornece "O trovão é um som nas nuvens" (AP II, 94a, 7) ${ }^{147}$. Esse tipo de definição, observa o filósofo, "significa sem exibir a causa" $(94 \mathrm{a}, 1)^{148}$.

Ao contrário da definição nominal, a definição real revela a causa do fenômeno, sendo um "enunciado que exibe o por que algo é" $(93 \mathrm{~b}, 40)^{149}$. Esse enunciado, afirma o filósofo, é "como uma demonstração da essência, diferindo da demonstração quanto à posição dos termos” $(94 \mathrm{a}, 2)^{150}$. Por “demonstração" (apódeixis), Aristóteles entende, nesse contexto, a resposta à pergunta referente ao porquê do fenômeno: no intuito de responder à questão “por que troveja?” (dià tí brontâi;), tem-se, consoante a teoria física aceita pelo filósofo, "porque o fogo extingue-se nas nuvens" (94a, 4) $)^{151}$. A definição real, diferentemente da demonstrativa, responde à pergunta concernente à essência: " $\mathrm{O}$ que é o trovão? (tí d'estì bronté;) É um som que ocorre devido à extinção do fogo nas nuvens." $(94 \mathrm{a}, 5)^{152}$. De um ponto de vista formal, portanto, definições reais articulam, em uma mesma proposição, os três termos do silogismo da essência (GUTHRIE, 1981, 176): em seu definiens, estão expressos tanto a causa quanto o significado do fenômeno ${ }^{153}$.

Sob uma perspectiva sintática, a qual se limita à organização dos termos e dos enunciados na arquitetura da prova, a cada uma das definições atribui-se uma posição específica dentro do contexto argumentativo:

Em um primeiro sentido, definição é um enunciado indemonstrável da essência; em um segundo sentido, é uma inferência da essência, diferindo da demonstração quanto à disposição de seus termos; em um terceiro sentido, é a conclusão da demonstração da essência ( $A P$ II, $94 \mathrm{a}, 10-14)^{154}$.

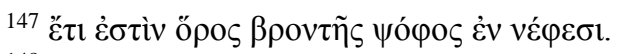

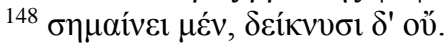

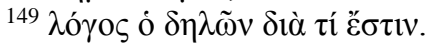

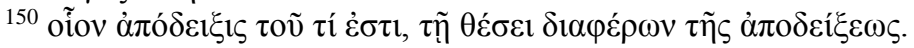

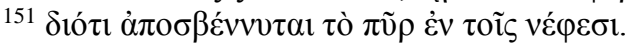

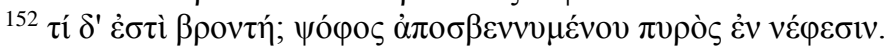

153 “O que Aristóteles procura em uma definição científica não é um mero truísmo analítico, mas o conhecimento substantivo da essência de algo.” (BURNYEAT, 2012, 125).

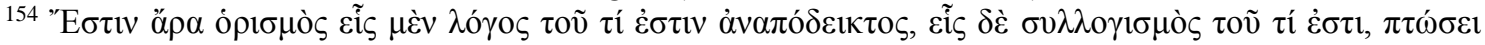

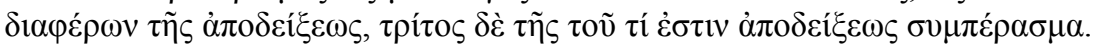


As questões semânticas relativas ao conteúdo expresso por cada um dos enunciados definitórios através de sua estrutura interna particular influem, assim, sobre a organização das proposições constituintes da prova quiditativa. De acordo com Aristóteles, por exemplo, as expressões do ser e da causa são indemonstráveis - "a definição dos imediatos consiste em uma suposição indemonstrável da essência." (94a, 9) ${ }^{155}$-, não podendo, ipso facto, aparecer na conclusão da prova da essência ${ }^{156}$. Desse modo, o conteúdo expresso pela definição determina seu locus no contexto argumentativo; em outras palavras, não é arbitrária, na prova da essência, a posição dos enunciados definitórios.

\subsection{A prova quiditativa}

Tendo-se em vista tais considerações, é legítimo indagar acerca da forma apropriada para a construção de uma prova quiditativa. Em uma passagem anterior ao trecho supracitado, Aristóteles fornece um exemplo de silogismo demonstrativo da essência, mostrando não apenas a estrutura formal a ser aplicada, mas também o modo como as definições são utilizadas na tarefa de arquitetá-lo:

O que é o trovão? É a extinção do fogo na nuvem. Por que troveja? Por conta de o fogo extinguir-se na nuvem. Seja C "nuvem", "trovão" A e "extinção do fogo", B. De C, "nuvem", predica-se B, pois o fogo extingue-se na nuvem. De B, predica-se A, som - B é a explicação de A, o termo maior. (AP II, 93b, 8-13) ${ }^{157}$.

Uma vez abstraído o conteúdo das proposições, vem à tona a seguinte forma subjacente:

A predica-se de $\mathrm{B}$

B predica-se C

A predica-se $\mathrm{C}$

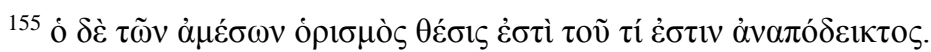

${ }^{156}$ Apesar de o enunciado da essência não poder ser demonstrado em um silogismo quiditativo, ele certamente é expresso por meio dessa construção: "A definição de alguns itens pode ser expressa ou esclarecida em um silogismo demonstrativo apropriado." (ACKRILL, 1981, 359-384).

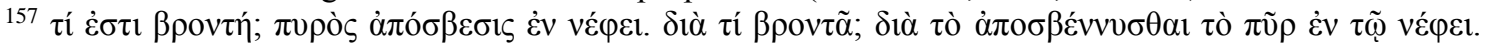

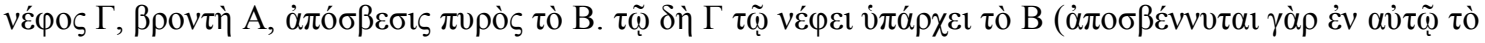

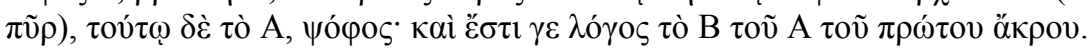


Interpretando-se cada termo a partir de sua função dentro do contexto dos enunciados definitórios, tem-se o seguinte esquema, o qual estabelece o modo apropriado de articular definição e demonstração:

\begin{tabular}{|c|c|c|}
\hline $\begin{array}{c}\text { Classificação } \\
\text { conforme à } \\
\text { posição no } \\
\text { silogismo }\end{array}$ & Simbolização & $\begin{array}{c}\text { Interpretação conforme ao } \\
\text { conteúdo das definições }\end{array}$ \\
\hline Termo maior & $\mathrm{A}$ & Núcleo do definiens da definição nominal \\
\hline Termo médio & $\mathrm{B}$ & Parte do definiens da expressão da essência ${ }^{158}$ \\
\hline Termo menor & $\mathrm{C}$ & Complemento do definiens da definição nominal \\
\hline
\end{tabular}

Levando-se em conta, pois, tanto a forma do argumento quanto o esquema interpretativo para os termos singulares, tem-se, no caso do fenômeno do trovão, o seguinte silogismo:

Som predica-se da extinção de fogo

Extinção de fogo predica-se da nuvem

Som predica-se da nuvem ${ }^{159}$

Tal construção adequa-se ao exposto em 94a, 14, visto que seu enunciado conclusivo reflete a definição nominal de trovão enquanto um som localizado nas nuvens. Além disso, o uso do definiens da definição quiditativa como termo médio conforma-se à restrição semântica apresentada em 93a, 8: "É necessário que o termo médio seja a causa". ${ }^{160}$ Cabe notar que Aristóteles, ao expor os termos a serem utilizados na construção do silogismo, estabelece "trovão" como o termo maior; contudo, no momento de postular as relações predicativas, opta por "som", o qual se

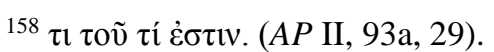

159 "Nessa primeira tentativa de elaboração de um método científico, Aristóteles poderia apenas baseá-lo na relação sujeito-predicado, e o que vemos como eventos cuja relação a ciência investiga apareça sob o disfarce de propriedades dos sujeitos aos quais elas ocorrem, atributos fluindo de sua essência. Em vez de traçar uma sequência de eventos causalmente conectados, ele pensa em termos da tarefa de tomar um sujeito e revelar todos os seus atributos essenciais." (GUTHRIE, 1981, 177).

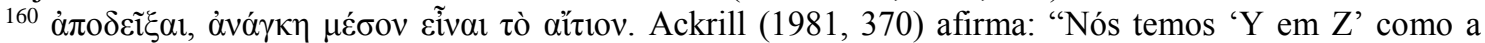
explicação inicial do investigador acerca do que X é e 'Y em Z por conta de $M$ ' como sua explicação final."
} 
refere a apenas uma parte do definiens da definição nominal. Sintaticamente, tal escolha permite que este apareça em sua totalidade na conclusão.

O silogismo demonstrativo da essência não apenas exibe as relações efetivas entre os estados de coisas, mas é a pedra de toque para legitimar a coexistência entre definições diversas do mesmo fenômeno. Desse modo, caso seja possível construir uma prova quiditativa envolvendo as duas definições de phantasía apresentadas no De Anima III, torna-se desnecessário o abandono de uma delas em detrimento da outra. Conciliar-se-iam, afinal, as noções de movimento intrapsíquico e de geração de imagens. A interpretação tradicional - segundo a qual a phantasía deve ser compreendida em termos de imagens mentais - ganharia força por meio das articulações internas à filosofia aristotélica da ciência, e não somente pelo prestígio dos célebres comentadores peripatéticos da antiguidade tardia ${ }^{161}$.

\subsection{Como conciliar 429a1 e 428a2?}

O primeiro passo para aplicar a forma da demonstração da essência ao caso particular da phantasía é classificar adequadamente suas definições. Aparentemente, tem-se, mais próximo ao início do estudo detalhado do De Anima III.3, a apresentação da definição nominal - "a phantasía é aquilo de acordo com o que um phántasma nos ocorre". Tal enunciado não revela a causa, mas, na melhor das hipóteses, apenas o significado do termo "phantasía", o qual se refere a algo responsável pela geração de imagens intrapsíquicas. De posse do fato de ocorrer algo na alma vinculado à produção de imagens e da definição nominal de phantasía, Aristóteles buscaria, em seguida, explicar esse fato, em conformidade com a ordem natural da investigação científica "procuramos o porquê estando já de posse do fato [...]." (93a 17) ${ }^{162}$. A causa do evento é fornecida, ao final do estudo, pela definição real: "a phantasía é um movimento causado pela sensação em ato”. À primeira vista, pois, as definições apresentadas nessa parte do tratado não se excluem mutuamente, visto tratarem-se, ao que tudo indica, de tipos diferentes de enunciados definitórios.

Temístio parece atribuir ao enunciado em 429a1 o peso de uma definição. Em sua célebre Paráfrase ao De Anima de Aristóteles, o comentador escreve que a

\footnotetext{
161 “A primeira análise sistemática da phantasía em termos de imagem mental é a oferecida pelo comentador peripatético Alexandre de Afrodísia, em seu ensaio acerca da psicologia aristotélica, o De Anima. Mais tarde, essa leitura foi adotada por outro comentador peripatético, Temístio, e então, com algumas modificações na teoria psicológica de apoio, pelos comentadores neoplatônicos do De Anima de Aristóteles." (TODD, 1981, 49).

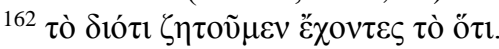


phantasía é "aquilo de acordo com o qual dizemos que um phántasma nos ocorre, como uma impressão ou a forma de um aísthẹma na alma.” (165, 2-3) ${ }^{163}$. Obviamente, Temístio antecipa a apresentação do vínculo entre os produtos da phantasía e da sensibilidade, interpretando a noção de phántasma a partir do resultado da atividade sensorial e de elementos tomados de empréstimo da iconografia. De certo modo, portanto, uma ideia estreitamente ligada à definição real apresentada ao término do $D e$ Anima III.3 é transposta para a descrição em 429a1, pressupondo-se, assim, a coexistência entre o caráter sensorial da phantasía e seu aspecto funcional, responsável pela produção de imagens intrapsíquicas fenomenologicamente semelhantes às sensações.

A leitura de 428a1 que atribui à descrição ali contida o peso lógico de uma definição parece haver atravessado os séculos, podendo ser encontrada em trabalhos de comentadores hodiernos cujo foco repousa sobre o tema da phantasía aristotélica e noções correlatas. Scheiter, por exemplo, escreve: “A phantasía pode ser definida como uma capacidade para produzir imagens, as quais são formas sensíveis primeiramente adquiridas através da percepção.” (2012, 260). Se o enunciado expresso em 428a1 representa, de fato, uma definição para o fenômeno investigado no De Anima III.3, os conceitos de faculdade e de imagem fazem-se necessários para a apreensão da essência daquele, sendo inviável, por conta disso, o abandono da interpretação tradicional em prol de uma leitura que abra mão de termos provenientes do universo das imagens.

Seja qual for o peso lógico do enunciado em 428a1, não se pode negligenciar o fato de a descrição fornecida em 429a2 consistir em uma definição real genuína. Se a interpretação tradicional estiver correta, i.e., se o conceito de imagem (phántasma) realmente for necessário para a definição de phantasía, a frase em 428a1 não deve, de acordo com as diretrizes esboçadas na teoria aristotélica da ciência, enquadrar-se como uma definição real, uma vez que o mecanismo da gênese do fenômeno denotado pelo definiendum não é expresso através dela, mas, antes, por meio da descrição apresentada ao final do capítulo, em 429a2.

O próprio Temístio, a despeito de haver contribuído enormemente, com seu comentário, para o fomento da interpretação clássica, não subtrai ao enunciado em 429a2 sua manifesta importância: “ela [i.e., a phantasía] é aquilo que nós dizemos ser o

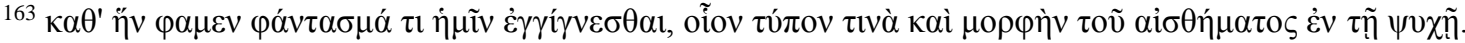


movimento da alma causado pela sensação tornada atual.” $(172,10)^{164}$. É uma constante no tratamento dispensado pelo célebre comentador peripatético ao tema do De Anima III.3 a articulação entre a descrição da phantasía nos termos da iconografia e seu relato causal a partir da sensibilidade: tal constante pode ser observada não apenas em 165, 23, onde o produto da phantasía é pensado, simultaneamente, a partir dos conceitos de týpos e aísthema - o primeiro, proveniente do contexto das imagens visuais, e o segundo, da teorização acerca da faculdade sensitiva -, mas também em 168, 4: "A phantasía é uma impressão e um rastro da sensação." ${ }^{165}$ Sendo assim, apesar de Temístio associar "todos os casos de phantasía com imagens mentais" (TODD, 1981, 52), nem todos esses casos são associados somente a tais imagens: não raro a sensação aparece como fator indispensável para uma caracterização apropriada da phantasía.

Visto que a asserção feita em 429a2 possui inegavelmente a estrutura de uma definição real genuína sem incorporar, como conteúdo, nenhum termo originário do domínio da iconografia, resta, para o defensor da interpretação tradicional, enquadrar a frase presente em 428a1 no conjunto das definições nominais. A princípio, portanto, o relato causal referente ao fenômeno da phantasía - o qual é construído não em termos de imagem, mas a partir dos conceitos de movimento e de sensação - não refutaria a interpretação tradicional, pois o enunciado "a phantasía é aquilo de acordo com o qual uma imagem nos ocorre" não seria apresentado como uma expressão da causa, mas do significado do definiendum, i.e., como um apontamento capaz de apreender verbalmente a referência do termo definido.

\subsection{Tentando enquadrar 429a1 em uma prova quiditativa}

Havendo sido as definições supostamente classificadas, torna-se possível, a partir de seu conteúdo e das indicações hauridas do esquema acima apresentado, determinar as premissas e a conclusão do silogismo apodítico-quiditativo referente ao fenômeno da phantasía. Logo no início da construção do argumento, contudo, uma questão de ordem técnica faz-se premente: como há de ser desmembrada o definiens da definição nominal de phantasía conforme exige a estrutura da demonstração quiditativa?

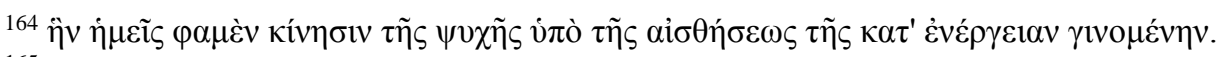

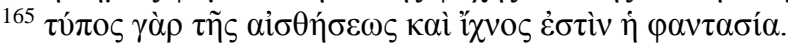


A definição semântica de trovão - "trovão é um som nas nuvens" - não oferece dificuldades a quem assume a tarefa de identificar as partes constituintes de seu definiens: núcleo e complemento ali articulam-se de tal modo que apenas um modelo de análise impõe-se como virtual. Diferentemente, o desmembramento da expressão "algo de acordo com o que um phántasma nos ocorre" - o definiens do enunciado definitório de phantasía - apresenta dificuldades, visto não ser óbvio a quais partes suas correspondem exatamente o núcleo e o complemento. Dois modelos de análise, nesse caso, mostram-se a princípios adequados.

De acordo com uma das análises formalmente possíveis, o núcleo e o complemento do definiens são identificados, respectivamente, com "algo de acordo com o que um phántasma ocorre" e "nós". A phantasía seria, desse modo, um dentre uma série de entes capazes de gerar imagens; seu traço característico consistiria, justamente, na capacidade de engendrar uma imagem para seres dotados de uma estrutura anímica específica. Nessa leitura, portanto, admite-se uma pluralidade de geradores de phántasma diversos da phantasía, não estando a ocorrência dos produtos de tais geradores limitada pela relação com os referentes do termo "nós", presente no complemento. Consequentemente, admitir-se-iam tipos variados de phántasma, os quais não poderiam ser caracterizados pela noção de imagem intrapsíquica, dado o vínculo entre essa noção e o conceito de phantasía.

A outra análise, por sua vez, traz como núcleo "algo de acordo com o qual nos ocorre", identificando o complemento com a expressão "um phántasma". Conforme a esse modo particular de decompor o definiens, a phantasía é entendida como um dentre uma multiplicidade de entes de acordo com os quais algo ocorre a seres dotados de certa estrutura anímica; sua diferenciação relativamente a esses outros entes dar-se-ia precisamente pela natureza da ocorrência por ela acarretada: os phantásmata não poderiam ser gerados por outros entes, mas ser-lhe-iam vinculados de modo exclusivo nada senão a phantasía pode, partindo-se dessa leitura, gerá-los.

Havendo, pois, um par de análises formalmente possíveis, a dificuldade consiste em optar por uma delas. A escolha não deve, em absoluto, ser aleatória, pois a definiç̧ão nominal fornece dois dos três termos da demonstração quiditativa, a qual não consiste em um silogismo meramente dialético, mas revela, articulando premissas verdadeiras e apodíticas, a conexão efetiva entre os fatos. Sendo ambas as análises adequadas do ponto de vista formal, deve-se determinar qual delas harmoniza-se com o pensamento exposto no De Anima acerca da phantasía. 
A primeira análise é corroborada pela existência de uma multiplicidade de sentidos dicionarizados do termo "phántasma"166. Levando-se em conta tais sentidos, não seria absurdo, à primeira vista, considerar a possibilidade de geradores de imagens ou aparições não acessadas de maneira exclusiva pelos entes sensitivos aos quais se refere o termo "nós" na definição semântica de phantasía. Poder-se-ia conceber, tendo-se em vista os significados de "phántasma" enquanto fenômeno ou portento - i.e., significados objetivos -, até mesmo geradores cujos produtos podem não vir a ser apresentados a tais entes. Todavia, "phántasma", no contexto das obras psicológicas de Aristóteles, denota uma aparência completamente interiorizada, de modo que a ocorrência de um phántasma é sempre relativa a seres cuja estrutura anímica comporta a phantasía. A identificação do núcleo do definiens como "aquilo de acordo com o qual um phántasma ocorre" e do complemento como "nós", portanto, apesar de formalmente adequada, mostra-se errônea diante da necessidade do vínculo existente entre os conceitos de phántasma e phantasía. Decompor o definiens desse modo acarreta a separação de duas noções que, no De Anima, conectam-se tão estreitamente quanto aísthesis e aísthema.

A outra análise, além de formalmente adequada, não apresenta divergência alguma relativamente à leitura aristotélica do par conceitual phantasía-phántasma. Identificando-se o complemento do definiens como "um phántasma", não se efetua a dissociação entre os elementos do par, visto que a característica diferenciadora em relação a outras entidades reside precisamente nessa parte do definiens. Todavia, não somente a preservação do vínculo mencionado testemunha a favor desse modo específico de análise, mas também a ideia subjacente ao núcleo do definiens, por ele identificado como "aquilo de acordo com o qual nos ocorre", harmoniza-se facilmente com os pressupostos da teoria aristotélica da alma. A partir da análise ora sob exame, a phantasía, no contexto da definição semântico-nominal, é concebida enquanto pertencente a um conjunto de entidades psíquicas caracterizadas pela capacidade de gerar algo ocorrente aos seres denotados pela expressão "nós", a qual se encontra articulada no núcleo do definiens. Se na análise anteriormente considerada não era possível fornecer, de imediato, outros exemplos além do caso da phantasía - aos quais corresponderiam a caracterização do núcleo do definiens -, nesse outro modelo de análise torna-se trivial conceber outras entidades capazes de satisfazer a expressão

166 O Greek-English Lexicon lista "aparição", "fantasma”, "visão", “sonho”, "fenômenos” e "portentos" esses dois últimos referentes ao vocábulo no plural. 
"aquilo de acordo com o qual nos ocorre": o intelecto, por exemplo, em uma definição nominal expressa nos moldes do enunciado fornecido no De Anima III.3 para a phantasía, pode ser adequadamente descrito pela expressão "aquilo de acordo com o qual uma intelecção nos ocorre"; na mesma linha de raciocínio, à sensação corresponderia o enunciado "aquilo de acordo com o qual um aísthema nos ocorre".

Uma vez efetuada a análise da suposta definição semântico-nominal de phantasía, tem-se a totalidade dos termos envolvidos na demonstração quiditativa referente a esse fenômeno. O termo maior, identificado como o núcleo do definiens da definição nominal, conforme à tabela acima apresentada, deve ser obtido a partir de uma adaptação de "aquilo de acordo com o qual nos ocorre"; a expressão "algo com capacidade gerativa relativamente a nós" capta adequadamente a ideia por trás do núcleo do definiens da definição semântico-nominal, podendo ser utilizada como termo maior da demonstração quiditativa referente ao fenômeno da phantasía. De acordo com o mesmo parâmetro interpretativo, os termos médio (núcleo do definiens da expressão da essência) e menor (complemento do definiens da definição nominal) consistem, respectivamente, em "sensação em ato" e "phántasma". A partir desse modelo, constróise o seguinte silogismo:

Algo com capacidade gerativa relativamente a nós predica-se de sensação em ato Sensação em ato predica-se de phántasma

Algo com capacidade gerativa relativamente a nós predica-se de phántasma

A conclusão desse argumento corresponde, obviamente, ao definiens da suposta definição nominal de phantasía. Além disso, outro critério para a elaboração da prova quiditativa é satisfeito pelo silogismo, a bem dizer, o funcionamento de parte do definiens da definição real como explicação do termo menor: a sensação em ato - de um ponto de vista lógico, o termo médio da demonstração da essência - é, sob uma perspectiva metafísica, a causa do phántasma. Dessa forma, parece ser possível articular ambas as caracterizações de phantasía presentes no De Anima III.3 no contexto de uma prova quiditativa genuína.

De acordo com as indicações fornecidas nos Segundos Analíticos, fato e causa $\left(A P\right.$ II, 93a, 36) ${ }^{167}$ - se articulam por meio do termo médio no contexto da

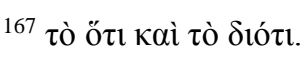


demonstração quiditativa. Ao tratar da prova relativa ao fenômeno do eclipse, Aristóteles afirma: "Investigar se um eclipse ocorre ou não é investigar se B existe ou não.” (AP II, 93a, 31) ${ }^{168}$. Na construção proposta acima envolvendo o termo "phantasía", a referência do termo médio atua da mesma forma: a sensação em ato garante não apenas a explicação para o fato da phantasía, mas a própria existência deste depende da atualização da faculdade sensitiva. Em outras palavras, investigar se a phantasía ocorre ou não equivale a investigar se há ou não sensação em ato. Tal conexão entre fato e causa por meio do termo médio de uma prova quiditativa dá-se exclusivamente no caso em que as premissas são imediatas, i.e., não provenientes de demonstrações anteriores: "Se as premissas forem imediatas, conhecemos o fato e causa simultaneamente.” (AP II, 93a, 36) ${ }^{169}$. As premissas do último argumento exposto são, obviamente, imediatas, visto que o termo por ambas partilhado provém da definição real de phantasía. Dessa forma, saber que a phantasía ocorre equivale a saber que ocorreu a atualização da faculdade sensitiva.

\subsection{Seria 428a1 realmente uma definição?}

Contudo, pode-se questionar a adequação do silogismo acima construído, visto que o enunciado presente em $D A 427 \mathrm{~b} 28$, diferentemente das definições semânticas de eclipse e trovão fornecidas nos Segundos Analíticos, não possui em seu definiens qualquer elemento em comum com o definiens da definição causal de phantasía. Aristóteles insere, ao construir as definições nominais relativas aos fenômenos do eclipse e do trovão, o gênero de cada um, parte integrante do definiens das respectivas definições reais; dessa forma, "som nas nuvens" e "privação de luz" aparecem em ambas as classes de enunciados definitórios. Todavia, a descrição contida em $D A$ 427 b28 não partilha qualquer nota em comum com o definiens da definição real de phantasía. Tendo-se em vista tal diferença, parece legítimo, à primeira vista, questionar se o enunciado presente em $D A 427 b 28$ constitui de fato uma definição semânticonominal. A adequação do silogismo acima enquanto exemplo de demonstração da essência depende, inevitavelmente, da resposta positiva a esse questionamento. Consequentemente, pende sobre a possibilidade dessa resposta a conciliação entre as noções de movimento intrapsíquico e geração de imagens a partir da perspectiva

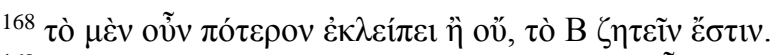

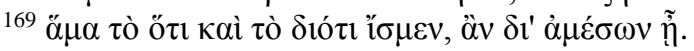


temistiana, visto ser a existência da prova quiditativa a pedra-de-toque para articular ambos os aspectos da phantasía, cada um veiculado por um enunciado diverso.

Faz-se necessário, pois, englobar a descrição apresentada em $D A 427$ b28 sob a classe das definições nominais. Dois argumentos de natureza diversa parecem, sob um primeiro olhar, servir a tal propósito. O primeiro deles parte da própria ideia de definição nominal e conclui a superfluidade da exigência de um elemento comum entre os definientes daquela e da definição real; o segundo, por sua vez, retira do texto dos Segundos Analíticos e do De Anima um possível contraexemplo para a tese segundo a qual o gênero do definiendum deve estar presente tanto na definição real quanto na definição nominal.

Ao conceber a definição nominal como um "enunciado do que significa o nome ou outra expressão nominal” ( $A P$ II, 93b, 30), Aristóteles enfatiza o caráter referencial desse tipo de enunciado. Ora, não há qualquer restrição lógica que prive um enunciado definitório de sua capacidade referencial em virtude de não estar nele contido como nota o gênero do definiendum. Sob um viés estritamente formal, portanto, um enunciado pode significar (semaínein) - i.e., estabelecer o vínculo entre o nome e sua referência extralinguística - independentemente de apresentar ou não elementos em comum com o definiens da definição real. Sendo assim, a descrição presente em $D A 427 \mathrm{~b} 28$, por possuir a forma de um enunciado definitório e por cumprir plenamente sua função referencial sem informar acerca da causa da phantasía, consistiria em uma definição semântico-nominal genuína, a despeito de não conter como nota integrante em sua estrutura o gênero ao qual sua referência pertence - no caso, o movimento, como explicita a definição apresentada em $428 b 30$.

O segundo argumento para justificar a presença do enunciado fornecido em $D A$ 428a1 na classe das definições nominais possui um caráter estritamente exegético. Ao tratar da necessidade de se apreender previamente a existência do estado de coisas para que haja conhecimento da essência, Aristóteles afirma:

É impossível saber a essência de alguma coisa quando se ignora se ela existe. Às vezes, sabemos acidentalmente que algo existe; às vezes, sabemo-lo estando de posse de algo da essência, como que o trovão é certo som nas nuvens, que o eclipse é certa privação de luz, que o ser humano é certo animal e que a alma é algo que se move a si mesmo. $(A P \text { II, 93a, 20-24) })^{170}$.

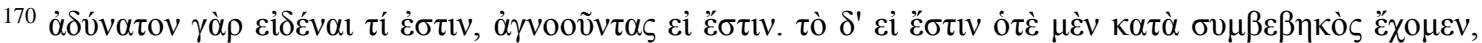

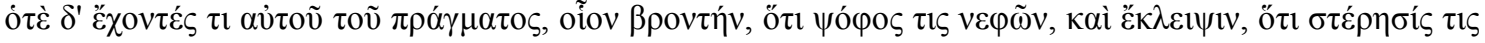

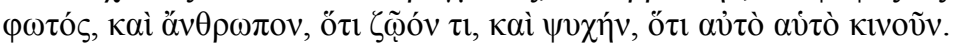


Nos três primeiros exemplos, tem-se o gênero presente também na definição real de cada entidade - "som nas nuvens", "privação de luz" e "animal" são notas constituintes das definições reais de trovão, eclipse e ser humano, respectivamente. Na definição de alma fornecida no De Anima, contudo, não aparece como elemento a capacidade automotora: "a alma é a primeira atualidade de um corpo natural que tem em potência a vida." (DA II, 412a, 27). Tal enunciado insere a alma no gênero das atualidades primeiras e a diferencia do restante destas a partir de sua relação com um tipo específico de corpo natural - aquele que contém potencialmente a vida. Desse modo, não há elemento comum entre o definiens do enunciado presente em DA II, 412a, 27 e a definição nominal de alma listada no livro II dos Segundos Analíticos.

Ao mencionar o caso da alma, porém, surgem algumas dificuldades: em primeiro lugar, a concepção de alma como capaz de movimento não condiz com a doutrina expressa no De Anima - “a alma não é capaz de se mover" (DA I, 408b, 30$31)^{171}$; em segundo lugar, é razoável supor que o exemplo referente à alma na passagem supracitada dos Segundos Analíticos seja do platônico Xenócrates (POLANSKY, 2007, 118) e consista, assim, em um mero recurso didático, o qual não compromete o filósofo com a ideia de uma alma em cuja essência se encontre a capacidade de movimento. Ambas as dificuldades apontam, pois, em direção à necessidade de a definição semântica possuir um elemento em comum com a definição real, i.e., aquela deve possuir uma nota que expresse algo da essência da entidade descrita pelo enunciado definitório, ao menos enquanto serve de premissa no contexto da prova quiditativa.

Cabe notar que o caso da alma fornece um contraexemplo à tese segundo a qual o gênero deve ser o elemento comum entre os dois tipos de definição. Xenócrates, ao definir aquela como um número capaz de mover a si mesmo, insere-a no gênero número, diferenciando-a por meio da capacidade de engendrar o próprio movimento. Dessa forma, quando Aristóteles toma essa capacidade para determinar uma suposta definição semântico-nominal de alma, ele não extrai o gênero contido na definição real, mas a diferença. Isso condiz com o caráter do pronome indefinido " $t i$ " na frase " $t i$ autôิ toû prágmatos", a qual não determina qual parte do definiens da definição real deve estar presente na definição nominal. A princípio, então, para cada definiendum há duas

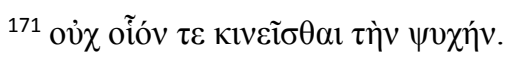


definições nominais formalmente possíveis - uma construída a partir do gênero, e outra, a partir da diferença.

Como pode ser observado pela leitura dos Segundos Analíticos, a primeira descrição de phantasía apresentada no De Anima III não pode ser tomada, sob uma perspectiva puramente exegética, como uma definição nominal genuína, dada a exigência de um elemento comum entre esta e a definição real. Tal exigência enfraquece também o primeiro argumento, visto que na lógica aristotélica, ao que parece, não se pode pensar o significar/referir independentemente das intensões necessárias para a formulação do enunciado definitório real.

Não obstante as imperfeições dos argumentos acima - só evitadas na hipótese de o exemplo da alma em 93a, 24 consistir em uma quebra de paralelismo relativamente aos casos anteriores -, o seguidor de Temístio talvez possa lançar mão de outro subterfúgio a fim de proceder à construção da prova quiditativa da phantasía sem a indesejável consequência de ter que se abandonar uma das descrições fornecidas no $D e$ Anima III.3. Tal subterfúgio consiste em se tomar ambos os enunciados como partes de definições, ao invés de definições completas.

Nessa abordagem, as descrições são mutuamente complementares, visto que uma fornece à outra o predicado a ser inserido a fim de engendrar o enunciado completo. Na primeira descrição - "phantasía é algo de acordo com o qual um phántasma nos ocorre" - o termo assimilado é "movimento", gênero que compreende o fenômeno da phantasía (o uso do predicado "causado pela sensação em ato" descaracterizaria o enunciado resultante enquanto definição semântico-nominal). Temse, assim, a seguinte definição, a qual expressa unicamente o significado do termo "phantasía": "phantasía é um movimento de acordo com o qual um phántasma nos ocorre". Tal construção é respaldada pelo uso do termo ao longo do primeiro livro do De Anima, onde a phantasía é concebida diversas vezes como um movimento, atividade ou afecção.

A segunda descrição - "phantasía é um movimento causado pela sensação em ato" - é complementada pela expressão "de acordo com o qual um phántasma nos ocorre", contida na definição semântico-nominal. Dessa forma, tem-se o seguinte enunciado: "phantasía é um movimento causado pela sensação em ato de acordo com o qual um phántasma nos ocorre" (a ordem dos predicados visa unicamente a evitar ambiguidade). Essa definição articula os aspectos fundamentais do fenômeno tal como concebido por Aristóteles, a bem dizer, sua natureza sensível, seu lugar no âmbito das 
mutações e sua função como matriz geradora de imagens intrapsíquicas. Analisando-se o definiens em suas partes integrantes, tem-se "movimento de acordo com o qual um phántasma nos ocorre" como o gênero e "causado pela sensação em ato" como a diferença específica. Tal análise é formalmente adequada de acordo com os parâmetros expressos nos Segundos Analíticos, onde as definições nominais são majoritariamente identificadas como gêneros ( $A P$ II, 93a 20-24): estas estão contidas, via de regra, na definição real.

Quanto à segunda definição proposta, uma questão surge imediatamente: a expressão "movimento de acordo com o qual um phántasma nos ocorre" pode representar um gênero? Tal expressão parece representar, afinal, uma mera classe unitária, diferentemente dos predicados "som nas nuvens", "privação de luz" e "animal", exemplificados por uma diversidade de espécies. Para responder negativamente a questão, faz-se necessário raciocinar dialeticamente, a partir de um locus causal.

Se no âmbito físico, de maneira geral, a causa da causa de um efeito pode ser afirmada, em certo sentido, como causa deste, a própria sensação é causa, tanto eficiente quanto formal - a expressão "kath'hèn" parece indicar a phantasía como causa do phántasma precisamente nesses dois sentidos -, do phántasma. Desse modo, a expressão "movimento de acordo com o qual um phántasma nos ocorre" surge como ambígua entre a sensação e a phantasía.

Ainda assim, a ambiguidade não é suficiente para configurar essa última expressão como um gênero: não se pode definir algo a partir de um conceito que não lhe seja essencial - a produção de imagens, apesar de necessariamente vinculada à sensação, não expressa a essência desta. Nenhuma estratégia, portanto, garante o status de definição ao enunciado que apresenta a phantasía como algo capaz de gerar imagens intrapsíquicas. A abordagem de Temístio, na qual ambas as descrições fornecidas no De Anima III encontram-se articuladas em uma única definição, colapsa ao defrontar-se com os moldes apresentados na teoria aristotélica da ciência para a estruturação de frases definitórias ${ }^{172}$.

\footnotetext{
${ }^{172}$ A tese segundo a qual a definição nominal deve falar algo da essência do objeto ou do fenômeno não é consensual entre os comentadores. Natali (2010, n. 6), por exemplo, em um artigo cuja proposta muito se assemelha à aqui realizada, afirma que tal definição pode fornecer apenas uma propriedade ou uma característica típica do definiendum. Ross (1957, 219), comentando os Segundos Analíticos, flerta com a mesma ideia.
} 
A definição nominal de phantasía, pois, não é representada pelo enunciado fornecido em $428 \mathrm{a}^{173}$, mas pelo núcleo do definiens do relato causal apresentado ao final do De Anima III.3. Desse modo, tem-se "movimento da alma" - "kínesin têes psykhêes", segundo a paráfrase de Temístio $(172,10)$-, o gênero ao qual pertence o fenômeno sob investigação, como expressão do significado do termo "phantasía". A prova quiditativa envolvendo as caracterizações da phantasía haveria, portanto, de ser estruturada da seguinte forma:

\section{Movimento predica-se de sensação em ato \\ $\underline{\text { Sensação em ato predica-se de alma }}$}

Movimento predica-se de alma

Obviamente, esse silogismo, a despeito de consistir em uma prova quiditiva genuína - o termo médio ("sensação em ato") expressa a causa e a essência do fenômeno, articulando, no contexto do argumento, os predicados não etiológicos do definiendum - não revela a articulação subsistente entre os fatos da origem sensorial da phantasía e de sua potência geradora de imagens. Mesmo estruturado de acordo com o outro modelo para a construção de demonstrações quiditativas presente nos Segundos Analíticos $^{174}$, o silogismo relativo ao caso da phantasía clarifica apenas as relações entre os termos extraídos do enunciado em 429a2:

\footnotetext{
${ }^{173}$ Isso não significa, contudo, que ele não possa ser utilizado como ponto de partida para a investigação acerca da natureza da phantasía: "Certamente um investigador de X pode chegar de modo bem sucedido ao conhecimento do que seja $X$ mesmo que ele identifique $X$, inicialmente, por meio de uma especificação ou descrição que não adentra a definição real de $\mathrm{X}$ - contanto que sua especificação ou descrição selecione, de fato, Xs." (ACKRILL, 1981, 373).

${ }^{174}$ Esse modelo, apresentado em 93a 30-31, posiciona o definiendum no lugar do termo maior, o complemento do definiens como termo médio e reserva a posição do termo menor para uma das partes do núcleo do definiens. No caso do eclipse, tem-se o seguinte argumento:
}

\section{Eclipse predica-se de obstrução pela Terra \\ Obstrução pela Terra predica-se de Lua \\ Eclipse predica-se de Lua}

Em seguida (93a37-93b4), Aristóteles fornece um exemplo de silogismo no qual o termo médio, apesar de representar um atributo essencial do fenômeno do eclipse, não expressa a causa deste:

Eclipse predica-se de não ser capaz de projetar sombra a despeito de não haver nada entre nós e a Lua

$\underline{\text { Não ser capaz de projetar sombra a despeito de não haver nada entre nós e a Lua predica-se de Lua }}$ Eclipse predica-se de Lua

Tratando da diferença entre os dois modelos de prova quiditativa - do trovão e do eclipse -, afirma Ackrill (1981, 363): "Ainda que os dois silogismos sejam bastante diferentes, ambos podem server ao intuito de Aristóteles. O primeiro é explicitamente sobre o que algo é, mas implica que esse algo existe, e 
Phantasía predica-se de sensação em ato

$\underline{\text { Sensação em ato predica-se de alma }}$

Phantasía predica-se de alma

Conclui-se, pois, que a não satisfação do critério representado pela existência de uma prova quiditativa capaz de articular os termos dos dois enunciados descritivos no De Anima III.3 (428a1 e 429a2) impossibilita o enquadramento do primeiro deles na classe das definições. Como consequência trivial dessa impossibilidade, tem-se a ausência do conceito de imagem na definição de phantasía - em outras palavras, a interpretação tradicional mostra-se equivocada no tocante ao papel desempenhado por tal conceito na constelação de noções vinculadas à phantasía aristotélica.

\section{8. $O$ engendramento de phantásmata como uma propriedade}

A conclusão recém-traçada, apesar de deslocar a noção de imagem do contexto da definição de phantasía, não equivale à defesa da tese segundo a qual o conceito aristotélico desse fenômeno apresenta-se completamente desvinculado do universo das imagens internas. A despeito de os termos "dýnamis" e "phántasma" não integrarem a expressão da essência da phantasía, ainda há espaço para se pensar a ideia de faculdade geradora de imagens como indissociavelmente ligada àquela, uma vez que a classe dos predicados necessários não é composta apenas pelos definientes. No primeiro livro dos Tópicos, Aristóteles apresenta um tipo diverso de predicação necessária, a propriedade:

Uma propriedade é aquilo que não revela a essência, mas predica-se exclusiva e conversivelmente da coisa. Por exemplo, uma propriedade do homem é o ser capaz de aprender gramática: se algo é homem, então é capaz de aprender gramática, e se algo é capaz de aprender gramática, então é homem. Ninguém diz que é uma propriedade algo capaz de ser predicado de outra coisa - por exemplo, ninguém diz que o dormir é uma propriedade do homem, ainda que calhe de ser, em um determinado momento, dele predicado exclusivamente. (Top. I, 102a, $17-25)^{175}$.

fornece todo o material para um silogismo do outro tipo. O segundo silogismo é explicitamente uma prova de que algo existe; mas também esclarece que esse algo é um item cientificamente inteligível."

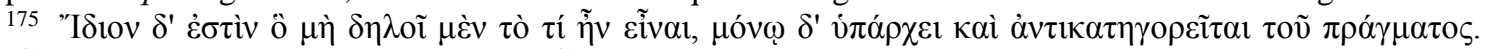

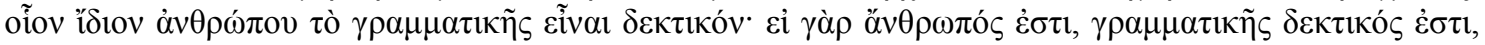

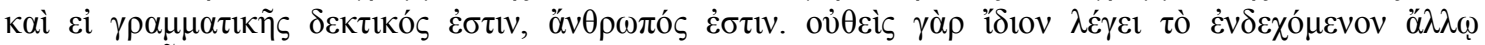

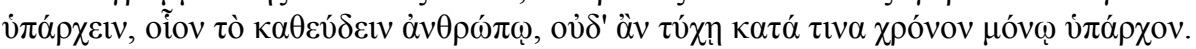


O reconhecimento, por parte do filósofo, de um tipo de predicação necessária que não expressa a essência do sujeito abre caminho para a reabilitação do enunciado presente em 428a1 como indispensável no contexto da investigação do conceito aristotélico de phantasía. A frase "aquilo de acordo com o qual um phántasma nos ocorre" não consiste, afinal, em um definiens, mas em uma propriedade, i.e., em uma expressão que, a despeito de não integrar a definição do fenômeno, não revelando aspecto algum de sua essência, predica-se necessariamente do termo sujeito.

De imediato percebe-se que o enunciado em 428a1 satisfaz ambos os critérios positivos para uma expressão consistir em uma propriedade - a co-extensão e a conversão com o sujeito -, bem como a condição negativa - não expressar nada acerca da essência da coisa. Parafraseando a passagem supracitada dos Tópicos: se algo é phantasía, então é capaz de nos gerar um phántasma, e se algo é capaz de nos gerar um phántasma, então é phantasía. Ainda que não seja, à primeira vista, tão clara a proveniência da capacidade geradora de imagens a partir do movimento causado pela sensação em ato - propriedades, segundo Aristóteles, seguem-se das essências, a despeito de não expressarem aspecto algum destas -, há indícios textuais suficientes para se afirmar com segurança a tese de acordo com a qual o enunciado em 428a1 tem o propósito de conectar phantasía e função geradora de imagens nos limites da relação objeto-propriedade. Se o vínculo existente entre a propriedade de possuir a soma dos ângulos internos equivalente a $180^{\circ}$ e a qualidade essencial de ser uma figura plana de três lados resulta muito mais claro que a conexão entre geração de imagens e movimento sensível atualizado, tal se deve a fatores incapazes de consistirem, por si ou em conjunto com outras observações, em uma refutação da tese defendida acerca de $428 \mathrm{a} 1^{176}$.

É possível, assim, salvaguardar a coexistência das duas descrições fornecidas no De Anima III.3: em 428a1 encontra-se uma propriedade do fenômeno ali investigado, e em 429a2, a expressão de sua essência. Ambas mostram-se indispensáveis para a compreensão da phantasía aristotélica, pois não expressam características meramente acidentais desta, mas, ao invés, enunciam seus aspectos necessários mais relevantes para

${ }^{176}$ Dentre os fatores que explicam a diferença mencionada, pode-se listar a maior clareza dos objetos abstratos relativamente às entidades psicofísicas e a brevidade da abordagem presente no De Anima a respeito da relação causal entre sensação em ato e engendramento de imagens. Pode-se citar um trecho do comentário de Barnes aos Segundos Analíticos $(2002,629)$ para fundamentar a diferença sobre uma distinção metafísica: "Há propriedades permanentes que possuem fundamento (não uma causa) em atributos mais fundamentais de seus objetos (como no caso das propriedades geométricas), e há eventos que possuem uma causa em outros eventos que calham de ocorrer a seus sujeitos (como no caso do eclipse ou do trovão).” 
a compreensão do engendramento de imagens em um contexto de cooperação entre as diversas faculdades anímicas ${ }^{177}$.

\subsection{A ideia de função afetiva/afecção funcional}

O uso do conceito de phantasía como fenômeno psíquico, em suma, não é exógeno ao arcabouço linguístico-conceitual do De Anima, mas está, desde o início, previsto no conjunto das possibilidades terminológicas da obra. O fato de a descrição presente em $429 \mathrm{a} 2$ consistir em um enunciado definitório genuíno estabelece a não acidentalidade do vínculo entre as ideias de phantasía e fenômeno psíquico, visto que a noção de movimento faz-se necessária na formulação daquela - a essência da phantasía reside no movimento intrapsíquico acarretado pela atualização da faculdade sensitiva. Nesse sentido, Aristóteles não efetua um deslocamento categorial do conceito de phantasía - esta permanece sendo um fenômeno psíquico, tal como era o caso na visão platônica acerca do tema -, mas apropria-se das linhas gerais herdadas da tradição precedente, modificando-a apenas no tocante ao caráter não discursivo da phantasía.

O fato de a conclusão da análise levada a cabo no De Anima III.3 pautar-se nos conceitos de movimento e sensação mostra que abordagem aristotélica não traz meros resquícios de desenvolvimentos anteriores, mas representa uma verdadeira continuidade em relação ao horizonte por estes inaugurado. Ao definir a phantasía como movimento causado pela sensação em ato, Aristóteles estabelece não apenas um vínculo entre aquela e a ideia de fenômeno ou acontecimento intrapsíquico, mas também entre seu conceito de phantasía e a abordagem de Platão referente ao tema. Esta, no entanto, não se infiltra no texto do De Anima como um elemento exógeno artificialmente assimilado pela noção aristotélica, mas é admitida, em suas linhas mais gerais, desde o princípio no universo conceitual da obra - a conexão entre phantasía e movimento, como foi

\footnotetext{
$177 \mathrm{O}$ fato de o enunciado expresso em 428a1 não trazer nenhum elemento em comum com o definiens da definição real não diminui seu valor no contexto da investigação científica: 'Seja 'Q' a ideia inicial do investigador acerca de $\mathrm{X}$. A exigência rígida é que apenas onde $\mathrm{Q}$ faça parte da definição real será possível para o investigador esperar alcançar conhecimento da definição real de X. Mas certamente há vários outros casos em que o sucesso pode com razão ser esperado: onde $Q$ é (a) uma propriedade peculiar a X (ídion), ou (b) de outro modo esteja necessariamente ligado a X, ou (c) não necessariamente mas de fato universalmente ligado a $\mathrm{x}$, ou (d) não universalmente mas quase sempre ligado a X. Em qualquer um desses casos o investigador está em algum tipo de posição para investigar os itens corretos e aprender mais sobre eles." (ACKRILL, 1981, 373-374). Propriedades podem, assim, ser utilizadas como ponto de partida na investigação empreendida com o propósito de se chegar à essência do objeto ou do fenômeno.
} 
mostrado acima, não se limita à definição apresentada ao final do De Anima III.3, visto que o vocabulário empregado nos dois primeiros livros já sugeria sua existência ao apresentar o termo "phantasía" juntamente com palavras utilizadas para designar movimentos intrapsíquicos e afecções.

A investigação acima apresentada permite concluir, de modo legítimo, a impossibilidade, no contexto da obra de Aristóteles, de se tratar as noções de função anímica e afecção como absolutamente dicotômicas. Sendo ambas as noções utilizadas para caracterizar o fenômeno da phantasía, torna-se inviável tratar o par conceitual como indicador de uma cisão insuperável entre o âmbito dos movimentos intrapsíquicos e o domínio das funções anímicas. O caso da phantasía revela, ao contrário, que tais conceitos por vezes se sobrepõem, de modo a poder-se afirmar, sem extrapolações indevidas, que Aristóteles concebia a phantasía como uma função afetiva (ou, equivalentemente, como uma afecção funcional).

Para o filósofo, portanto, um movimento intrapsíquico pode ser considerado não apenas sob o aspecto de sua gênese - cuja explicação deve, naturalmente, fazer referência a objetos externos ou a uma afecção de natureza diversa -, mas também enquanto uma faculdade gerativa. Funções anímicas devem ser consideradas, pois, não apenas enquanto partes estáticas de uma estrutura puramente ativa, mas também em seu aspecto dinâmico, o qual não se resume à passagem da potência ao ato. 


\section{CONCLUSÃO}

Buscou-se, ao longo do percurso, seguir aquilo que fora prometido nas páginas introdutórias - abordar o uso do termo "phantasía" na psicologia aristotélica a partir de uma perspectiva pluralista, reconhecendo e analisando todos os significados por ele assumidos. A despeito de cada capítulo orientar-se a partir de um eixo diverso, suas conclusões podem, quando tomadas em conjunto, formar uma resposta satisfatória às questões suscitadas pelo problema da polissemia, a bem dizer, a questão a respeito da real dimensão da ruptura aristotélica no tocante ao tema da phantasía, a questão da consistência interna face a diferentes descrições do fenômeno e a questão da relevância filosófica do sentido não psicológico do termo.

Com o primeiro capítulo, evidenciou-se que o principal debate protagonizado por certos comentadores hodiernos, ao girar em torno da relação entre phantasía e imagem - uns afirmando a existência da relação, outros negando-a -, acaba por negligenciar o vínculo muito mais estreito entre movimento intrapsíquico e phantasía, vínculo esse que pode fornecer as bases, inclusive, para se argumentar a favor de uma teoria unificada da phantasía aristotélica, ao menos no tocante à sua dimensão psicológica. Dessa forma, mostra-se que cada um dos lados está com uma parcela da razão: os que negam a possibilidade de reduzir a phantasía a termos de imagem o fazem corretamente, mas erram ao desacreditarem na existência de uma teoria unificada da phantasía psicológica; os que aceitam a possibilidade de redução erram ao apontar como termo ao qual deve ser reduzida a phantasía o conceito de imagem, mas acertam ao apostar na possibilidade de uma teoria unificada. Frente a um dos principais problemas impostos pela polissemia, o problema da consistência interna da psicologia de Aristóteles, a conclusão desta primeira parte do trabalho aponta, sem ainda determinar com absoluta segurança, para a inexistência de contradição na visão aristotélica da phantasía psicológica, visto que, por trás de cada fenômeno ligado a esta, é possível identificar uma causa psicofisiológica única, i.e., um movimento intrapsíquico de origem puramente sensorial. Buscou-se, ao final do capítulo, harmonizar uma das propostas gerais do presente trabalho - afirmar a multiplicidade semântica do termo sem comprometer a consistência da teoria aristotélica da alma com um dos traços característicos do filosofar de Aristóteles: a abordagem da polissemia dos termos sem o abandono de um núcleo semântico fundamental. Levandose em consideração apenas os sentidos psicológicos da phantasía, tal núcleo consiste na 
ideia de movimento intrapsíquico sensorial; considerando-se também o sentido não psicológico, o cerne identifica-se com o conceito de aparência, a qual pode ser tanto interna quanto externa.

A constatação segura da dimensão não psicológica da phantasía fica a cargo do segundo capítulo. A partir de uma passagem do De Sensu, em conjunto com algumas considerações do De Anima sobre o realismo de Aristóteles acerca dos objetos sensíveis, torna-se evidente que o termo "phantasía", quando atrelado a cores e outras entidades externas, adquire uma conotação essencialmente não psicológica. Com o auxílio de duas obras cosmológicas - De Caelo e Metereologica -, mostra-se que a phantasía não psicológica, além de comum nos escritos do filósofo, possui uma relevância filosófica tão grande quanto seu correlato psicológico, uma vez que os conceitos de aparência, evidência, fenômeno e manifestação são tão interessantes quanto as noções de imaginação e sensibilidade. Um estudo do De Coloribus, tratado escrito na escola peripatética, indica que o uso do conceito não psicológico de phantasía no De Sensu não é tão deslocado como se pode supor, mas essencial para a teoria aristotélica das cores. Quanto à influência da tradição precedente no uso feito por Aristóteles da phantasía não psicológica, fica claro que no próprio idioma helênico a relação entre "phantasía" e "phaínomai" acarreta o vínculo entre aquela e as noções de aparência, manifestação, fenômeno e aparecimento.

O último capítulo forneceu evidências terminológicas capazes de corroborar a tese segundo a qual os usos do termo feitos pelo filósofo trazem resquícios também da tradição platônica. A hipótese inicial não se limitava a asserir a existência do vínculo entre a abordagem aristotélica e certas heranças conceituais, mas dizia algo a respeito desse vínculo, a bem dizer, que ele seria, na verdade, mais arraigado do que normalmente se supõe. Tentou-se embasar a segunda parte da hipótese com a apresentação, no capítulo II, de uma gama de ocorrências de sentidos não psicológicos do termo "phantasía", bem como de um tratado, diretamente influenciado por Aristóteles, no qual se pode ler diversas passagens onde o termo surge com o mesmo sentido da ocorrência no De Sensu - para fundamentar a primeira parte da suposição, bastaria apresentar o caso desse último; no capítulo III, a análise não se limitou a constatar que o termo "páthos" ocorre tanto no texto de Platão quanto no de Aristóteles, mas desenvolveu-se em uma detalhada análise filosófico-semântica dos três livros do De Anima - tal estudo demonstrou haver mais ocorrências relacionando a ideia de phantasía com o conceito de movimento do que com a noção de faculdade. 
Relativamente à questão da consistência da abordagem de Aristóteles, o capítulo final apresenta um comentário, à luz dos Segundos Analíticos e dos Tópicos, das descrições de phantasía fornecidas no De Anima III.3. Tal estudo mostra que os enunciados ali contidos são absolutamente conciliáveis, uma vez que apenas um deles é apresentado como uma definição. Quanto à questão do significado da inovação de Aristóteles, mostra-se que, apesar de ele tratar a phantasía como uma faculdade, ela continua sendo uma afecção, sendo possível, assim, identificar o conceito de afecção funcional ou função afetiva.

Especular acerca da relação entre Aristóteles e a tradição que o precede é, certamente, mais seguro do que tentar encontrar uma explicação para a tendência, dominante entre os comentadores hodiernos, em focar no sentido de phantasía enquanto faculdade psíquica. No primeiro caso, é legítimo apelar para uma conexão histórica entre Aristóteles e seu mestre por meio de obras e exposições orais na Academia; da mesma forma, é razoável supor que o uso do vocabulário utilizado no De Sensu e no De Coloribus era corrente nas aulas dirigidas à audiência do Liceu. Quanto ao segundo caso, o peso da novidade apresentada por Aristóteles não parece ser suficiente para justificar a tendência observada nos comentadores hodiernos, uma vez em momento algum Aristóteles, ao abordar a phantasía sob um viés psicofísico, desvincula seu conceito das noções de movimento e afecção.

Após o trabalho de exegese, talvez seja permitido, nestas linhas finais, tecer uma ligeira crítica às interpretações recentes do conceito aristotélico de phantasía, sem pretender, com isso, emular as explicações totalizantes encetadas pelas filosofias da história da filosofia - o número insuficiente de fontes secundárias contempladas neste trabalho frustraria, obviamente, tal pretensão. O filósofo tcheco Vilém Flusser, o qual viveu e lecionou no Brasil ao longo das décadas de 1950 e 1960, certa vez escreveu:

Os quatro conceitos básicos de imagem, aparato, programa e informação sustentam bastante espontaneamente nosso pensamento cosmológico, e, ao fazê-lo, leva-nos bastante espontaneamente a procurar explicações funcionais. O mesmo aplica-se a outras áreas, como psicologia, biologia, linguística, cibernética e tecnologia da informação (para mencionar apenas alguns). Em todos, estamos já, de forma espontânea, pensando informaticamente, programaticamente, aparelhisticamente, imageticamente. Estamos pensando do modo como "pensam" computadores. (77-79) 
Para o pensador tcheco, uma crítica daquilo que por ele era denominado "funcionalismo", i.e., a tendência a interpretar tudo em termos de funcionalidades programadas, envolveria aspectos antropológicos, científicos, políticos e estéticos. Talvez seja justamente nesse ousado diagnóstico de época que se possa encontrar um norte para explicar a pouca atenção recebida pelos significados desviantes de phantasía por parte dos aristotelistas hodiernos. Se o sentido de faculdade psíquica é muito mais dócil a uma análise em termos do aparato conceitual que perpassa todos os âmbitos de uma visão de mundo hegemônica, é compreensível a negligência, observada na literatura secundária consultada nesta pesquisa, relativamente a sentidos menos propensos a repousarem na malha nocional do funcionalismo. Afinal, parece muito mais razoável falar do phántasma como um produto (output?) da função da phantasía do que da manifestação visual dos objetos externos como um produto de duas funções atuando em conjunto, uma intrapsíquica, outra no próprio âmago do cosmos - interpretar a cosmologia aristotélica em termos de funcionalidades programadas seria, certamente, um anacronismo imperdoável. Da mesma forma, torna-se pouco convincente enquadrar na perspectiva funcionalista algo que seja, simultaneamente, função e produto. Contudo, como o próprio Aristóteles utiliza o termo "função" em sua psicologia, tentou-se compreender, certas vezes, essa parte de sua obra a partir da perspectiva funcionalista.

Espera-se estar demonstrado, com o presente trabalho, que o interesse filosófico e semântico em relação ao termo "phantasía" pode se estender para além do sentido de faculdade psíquica, ou seja, para além dos limites traçados pela perspectiva funcionalista. A noção de phantasía como faculdade psíquica, apesar de uma inovação incontestável de Aristóteles, continua inseparável da noção platônica de phantasía como afecção, como o revelam o De Insomniis e a definição apresentada ao final do De Anima III.3. A ideia de uma afecção geradora, i.e., de um movimento intrapsíquico capaz de engendrar outro movimento, certamente ameaça a plausibilidade de um funcionalismo estrito, o qual enxerga a phantasía aristotélica como uma faculdade simpliciter e que, frente à pergunta "o que é a phantasía para Aristóteles", responde categoricamente, sem qualificação alguma: "a phantasía, para Aristóteles, é uma faculdade." Como um todo, o presente trabalho pode ser resumido com a seguinte réplica: "não apenas." 


\section{REFERÊNCIAS}

\section{EDIÇÕES DO DE ANIMA}

ARISTÓTElES. De Anima. Traduzido por R.D. Hicks. Cambridge: Cambridge University Press, 1907.

ARISTÓTELES. De Anima. Traduzido por M.C.G. dos Reis. São Paulo: Editora 34, 2006.

ARISTÓTEleS. De Anima. Traduzido por W.S. HETT. Cambridge: Harvard University Press, 2000.

ARISTÓTELES. De l’âme. Traduzido por J. Tricot. Paris: Vrin, 1934.

ARISTÓTELES. De l’âme. Traduzido por R. Bodéüs. Paris: Flammarion, 1993.

ARISTÓTELES. Sobre a Alma. Traduzido por A.M. Lóio. São Paulo: Martins Fontes, 2013.

\section{EDIÇÕES DE OUTRAS OBRAS DE ARISTÓTELES}

ARISTÓTELES. Analytica Posteriora. Traduzido por H. Tredennick. Cambridge: Harvard University Press, 1960.

ARISTÓTELES. De Insomniis. Traduzido por W.S. HETT. Cambridge: Harvard University Press, 2000.

ARISTÓTELES. De Caelo. Traduzido por W.K.C. Guthrie. Cambridge: Harvard University Press, 1971.

ARISTÓTELES. De Caelo. Traduzido por J.L. Stocks. Oxford: Clarendon Press, 1922.

PSEUDOARISTÓTELES. De Coloribus. Traduzido por T. Loveday e S. Forster. In: The Complete Works of Aristotle: The Revised Oxford Translation. Ed. Jonathan Barnes. Princeton: Princeton University Press, 1995, 1219-1228.

ARISTÓTELES. De Sensu et Sensibilibus. Traduzido por W.S. Hett. Cambridge: Harvard University Press, 2000.

ARISTÓTELES. Metafísica. Edição trilingue por V. G. Yebra. Madrid: Gredos, 1970.

ARISTÓTELES. Meteorologica. Traduzido por H.D. Lee. Cambridge: Harvard University Press, 1952. 
ARISTÓTELES. Meteorologica. Traduzido por E.W. Webster. Adelaide: The University of Adelaide Library, 2014.

ARISTÓTELES. Parva Naturalia. Traduzido por J.I. Beare e G.R.T. Ross. Oxford: Clarendon Press, 1931.

ARISTÓTELES. Parva Naturalia. Traduzido por W.A. Hammond. Londres: Swan Sonnenschein \& Co., LTD., 1902.

ARISTÓTELES. Posterior Analytics. Traduzido por Jonathan Barnes. Oxford: Clarendon Press, 2002.

ARISTÓTELES. Prior and Posterior Analytics. Traduzido por W.D. Ross. Oxford: Clarendon Press, 1957.

ARISTÓTELES. Seconds Analytiques. Traduzido por J. Tricot. Paris: Vrin, 1962.

ARISTÓTELES. Topica. Traduzido por E.S. Forster. Cambridge: Harvard University Press, 1960.

ARISTÓTELES. Topiques. Traduzido por J. Tricot. Paris: Vrin, 1974.

\section{COMENTADORES HODIERNOS}

ACKRILL, J.L. Aristotle's Theory of Definition: Some Questions on Posterior Analytics II 8-10. In: Aristotle on Science: The Posterior Analytics. Padova: Editrice Antenore, 1981, 359-384.

ANNAS, J. Aristotle on Memory and the Self. In: NUSSBAUM, M.; RORTY, A. Oxford: Oxford University Press, 1999.

ANNAS, J.; BARNES, J. The Modes of Scepticism. Cambridge: Cambridge University Press, 1985.

BARNEY, R. Appearances and Impressions. Phronesis, V. 37, 1992, 283-313.

BENARDETE, S. "De Anima” III. 3-5. The Review of Metaphysics, vol. 28, 197, 611622.

BLUMENTHAL, H.J. Neoplatonic Interpretations of Aristotle on "Phantasia". The Review of Metaphysics, V. 31, 1977, 242-257.

BUNDY, M.W. Plato's View of the Imagination. Studies in Philology, Vol. 19, 1922, 362-403.

BURNYEAT, M. Explorations in Ancient and Modern Philosophy. Cambridge: Cambridge University Press, 2012. 
CASTON, V. Porquoi Aristote a Besoin de l'Imagination. Les Études

Philosophiques, V. 1, 1997, 3-39.

- Aristotle and the Problem of Intentionality. Philosophy and Phenomenological Research, V. 58, 1998, 249-298.

Aristotle's Psychology. In: SHIELDS, C.; The Blackwell Guide to Ancient Philosophy. Malden-Oxford-Melbourne-Berlin: Blackwell Publishing Ldt., 2003.

DESLAURIERS, M. Aristotle on Definition. Leiden e Boston: Brill, 2007.

DÍAZ, M.E. Aísthesis y phantasía en el pensamiento aristotélico. In: DIAZ, M.E.; GRACIELA, M. (Org.). M. Surgimiento de la Phantasia en La Grecia Clásica: parecer y aparecer em Protágoras, Platón y Aristóteles. Buenos Aires: Prometeo, 2009.

DÍAZ, M.E.; LIVOV, G.R.; SPANGENBERG, Una introduccion a la phantasía antigua. In: DIAZ, M.E.; GRACIELA, M. (Org.). M. Surgimiento de la Phantasia en La Grecia Clásica: parecer y aparecer em Protágoras, Platón y Aristóteles. Buenos Aires: Prometeo, 2009.

FALCON, A. Aristotle on Causality. The Stanford Encyclopedia of Philosophy, 2014, $\mathrm{URL}=\langle$ http://plato.stanford.edu/archives/spr2014/entries/aristotle-causality/>.

FOLLON, J. La notion de phantasia chez Platon. In: LORIES, D.; RIZZERIO, L. Leuven: Peeters, 2003.

Aristote: Zoologie et Ethique. Revista Archai: As Origens do Pensamento Ocidental, V. 11, 2013, 101-110.

FREDE, D. The Cognitive Role of Phantasía in Aristotle. In: NUSSBAUM, M.; RORTY, A. Oxford: Oxford University Press, 1999.

GONZÁLES, J.M. The Meaning and Function of Phantasia in Aristotle's "Rhetoric" III.1. Transactions of the American Philological Association, V. 136, 99 131.

GOTTSCHALK, H.B. The De Coloribus and its Author. Hermes, V. 92, 1964, 59-85.

GUTHRIE, W.K.C. A History of Greek Philosophy: VI, Aristotle: An Encounter. Cambridge: Cambridge University Press, 1998. 
HUBERT, B. La phantasia d'après Aristote, De L'Âme, III, 3. Recherches Philosophiques, V. 1, 2005, 7-20

HUBY, P.M. Aristotle, De Insomniis 462a18. The Classical Quartely, New Series, Vol. 25, 1975, 151-152.

JOYCE, P. Imagining Experiences Correctly. Proceedings of the Aristotelian Society, New Series, Vol. 103, 2003, 361-369.

KALAÏTZIDIS, P. Imagination et Imaginaire Chez Aristote. Revue de Philosophie Ancienne, V. 9, 1991, 3-58.

LABARRIÈRE, J. Imagination humaine et imagination animale chez Aristote. Phronesis, V. 29, 1984, 17-49.

LEFEBVRE, R. La Phantasia chez Aristote: Subliminalité, Indistinction et Pathologie de la Perception. Les Études Philosophique, V.1, 1997, 41-58.

La crise de la phantasia: originalité des interpretations, originalité d'Aristote. In: LORIES, D.; Rizzerio, L. De la Phantasia à l'imagination. LouveinNamur-Paris-Dudley: Peeters-Société des études classiques, 2003.

Nature et fonction de la phantasia chez Aristote. In: LORIES, D.; RIZZERIO, L. Leuven: Peeters, 2003.

LEVI, A.W. The Two Imaginations. Philosophy and Phenomenological Research, Vol. 25, 1964, 188-200.

LYCOS, K. Aristotle and Plato on “Appearing”. Mind, Vol. 73, 1964, 496-514.

MARCOS, G.E. La Naturaleza de la phantasía platônica. Phantasía como 'mezcla' de sensación y juicio. In: DIAZ, M.E.; GRACIELA, M. (Org.). M. Surgimiento de la Phantasia en La Grecia Clásica: parecer y aparecer em Protágoras, Platón y Aristóteles. Buenos Aires: Prometeo, 2009.

MARQUES, M. Phantasia em Platão. Topicos, V. 28, 2005, 57-82.

MAUDlin, T. Aristotle: The Power of Perception by K.W. Modrak. The Philosophical Review, V. 99, 1990.

MODRAK, D. Aristotle: The Power of Perception. Chicago: University of Chicago Press, 1987.

MOSS, J. Aristotle on the Apparent Good: Perception, Phantasia, Thought, and Desire. Oxford: Oxford University Press, 2012.

NATALI, C. Posterior Analytics and the Definition of Happiness in NE I. Phronesis, V. 55, 2010, 304-324.

NOEL, J. Interpreting Aristotle's Phantasia and Claiming its Role Within Phronesis. Philosophy of Education, V. 2, 1997. 
NUSSBAuM, M. The Role of Phantasia in Aristotle's Explanation of Action. In: NUSSBAUM, M. Aristotle's De Motu Animalium: Text with Translation, Commentary, and Interpretative Essays. Princeton: Princeton University Press, 1985.

OELE, M. Aristotle on Pathos. Ann Arbor: Pro Quest Information and Learning Company, 2007.

O'GORMAN, N. Aristotle's 'Phantasia' in the "Rhetoric": 'Lexis', Appearance, and the Epideictic Function of Discourse. Philosophy \& Rethoric, V. 38, 16-40.

PAPACHRISTOU, C.S. Three kinds or grades of Phantasia in Aristotle's De Anima. Journal of Ancient Philosophy, V. 7, 2013, 19-48

POLANSKY, R. Aristotle's De Anima: A Commentary. Cambridge: Cambridge University Press, 2007.

SCHEITER, K.M. Images, Appearances, and Phantasia in Aristotle. Phronesis, V. 57, 2012, 251-278.

SCHOFIELD, M. Aristotle on the imagination. In: NUSSBAUM, M.; RORTY, A. Oxford: Oxford University Press, 1999.

SILVERMAN, A. Plato on "Phantasia". Classical Antiquity, V. 10, 1991, 123-147.

SOUSA, E. Filosofia Grega. Brasília: Editora UnB, 2012.

SPARSHOTT, F. Imagination: The Very Idea. The Journal of Aesthetics and Art Criticism, Vol. 48, 1990, 1-8.

STEWART, C. Erotic Dreams and Nightmares from Antiquity to the Present Author(s). The Journal of the Royal Anthropological Institute, V. 8, 2002, 279-309.

TODD, R. Themistius and the traditional interpretation of Aristotle's theory of phantasia. Acta Classica, V. 24, 1981, 49-59.

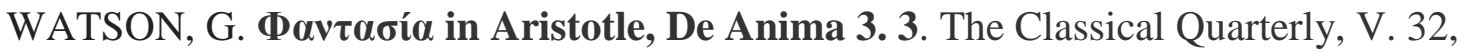
1982, 100-113.

Phantasia in Classical Thought. Galway: Galway University Press, 1988.

WEDIN, M.V. Mind and Imagination in Aristotle. New Haven: Yale University Press, 1988.

WHITE, K. The Meaning of Phantasia in Aristotle's De Anima, III, 3-8. Dialogue, V. 24, 1985, 483-505.

WRIGHT, M. The Theory of Imagination in Classical and Mediaeval Thought. Londres: Folcroft Library Editions, 1927. 


\section{OUTROS COMENTÁRIOS}

TEMÍSTIO. In Libros Aristotelis De Anima Paraphrasis. Berlin: Reimer, 1899.

GÓIS, M. Comentários do Colégio Conimbricense da Companhia de Jesus Sobre os Três Livros do Tratado 'Da Alma' de Aristóteles Estagirita. Traduzido por M.S. de Carvalho e M. Camps. Lisboa: Sílabo, 2010.

\section{OBRAS ANTIGAS}

HOMERO. Hinos. Traduzido por Evelyn-White. Cambridge: Harvard University Press, 1914.

PLATÃO. Sofista. Traduzido por H.N. Fowler. Cambridge: Harvard University Press, 1921.

\section{LÉXICOS}

DEZOTTI, M.; MALHADAS, D.; NEVES, M. (org.). Dicionário Grego-Português. Cotia: Ateliê Editorial, 2010.

PEREIRA, I. Dicionário Grego-Português e Português-Grego. Braga: Livraria Apostolado da Imprensa, 1998.

LIDDELL, H.G.; SCOTT, R.; JONES, H.S. A Greek-English Lexicon. Oxford: Clarendon Press, 1996.

\section{OUTRAS OBRAS}

FLUSSER, V. Towards a Philosophy of Photography. Londres: Reaktion Books, 2006. 